READABLE BOOKS IN NATURAL KNOWLEDGE

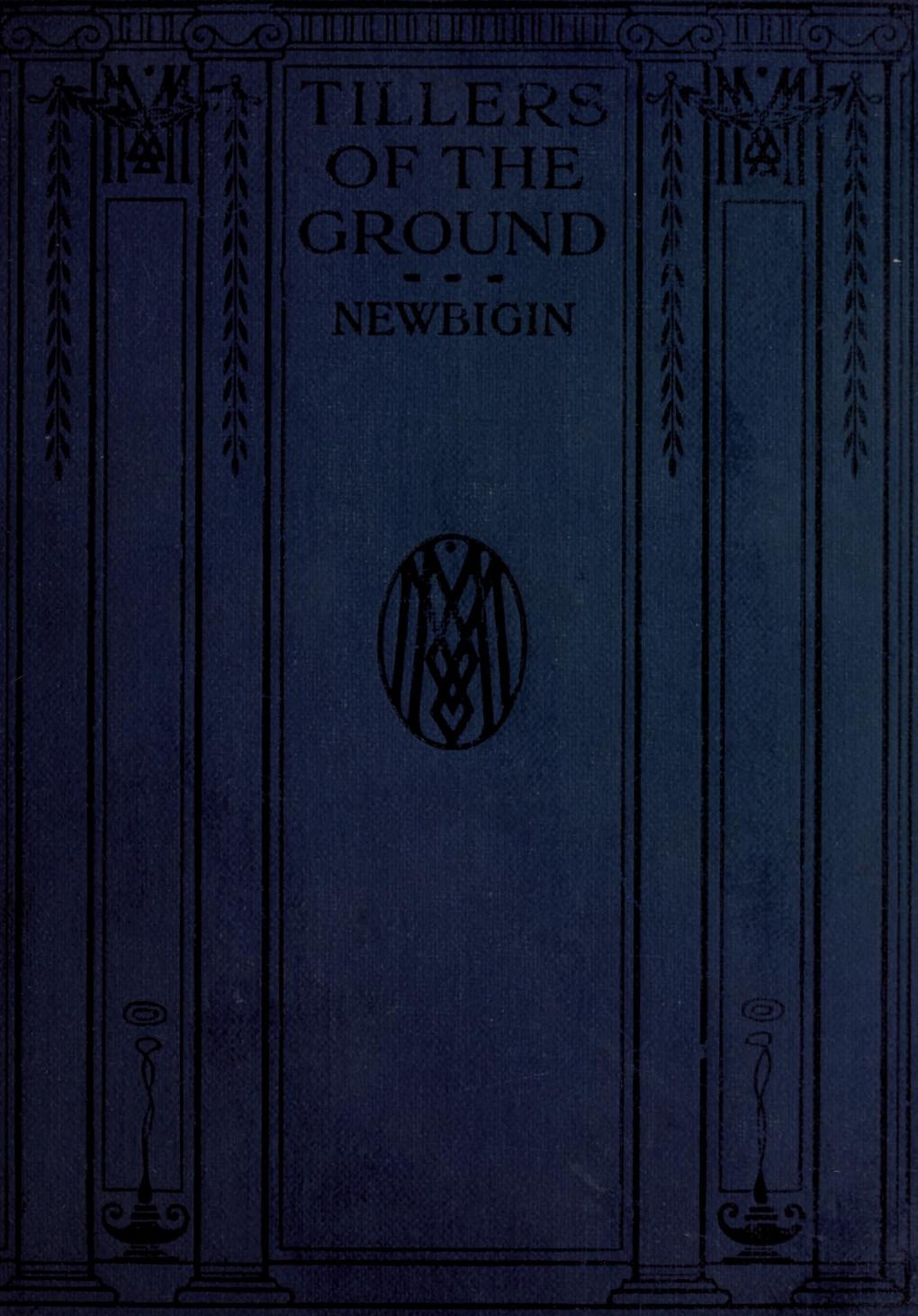


Thesenteo to

The Library University of Toronto

G. H. Arunctrong. aq. 




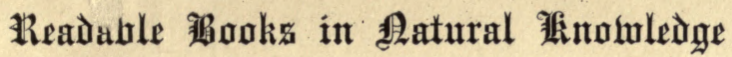

\section{TILLERS OF THE GROUND}




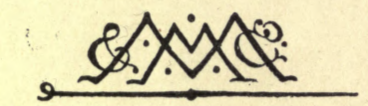
MACMILLAN AND CO., LIMITED
LONDON - BOMBAY - CALCUTTA MELBOURNE

THE MACMILLAN COMPANY

NEW YORK - BOSTON - CHICAGO

ATLANTA - SAN FRANCISCO

THE MACMILLAN CO. OF CANADA, LTD.

TORONTO 


\section{Agric \\ N}

\section{TILLERS}

\section{OF THE GROUND}

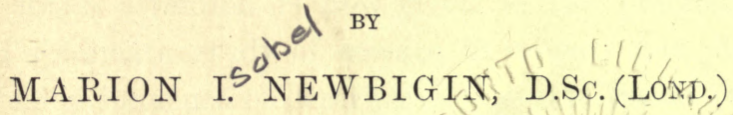

LECTURER IN ZOOLOGY AND BIOLOGY IN THE EDINBURGH SCHOOL OF MEDICINE FOR WOMEN; AND EDITOR OF THE "SCOTFISH GEOGRAPHICAL MAGAZINE"

"And those who husbanded the Golden Grain, And those who flung it to the Winds like Rain."

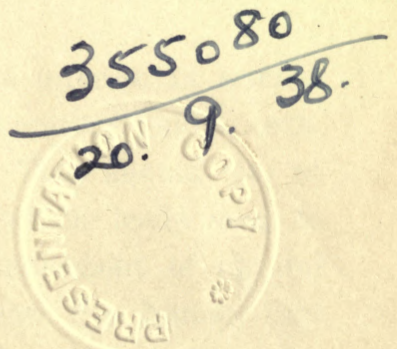

MACMILLAN AND CO., LIMITED ST. MARTIN'S STREET, LONDON . 


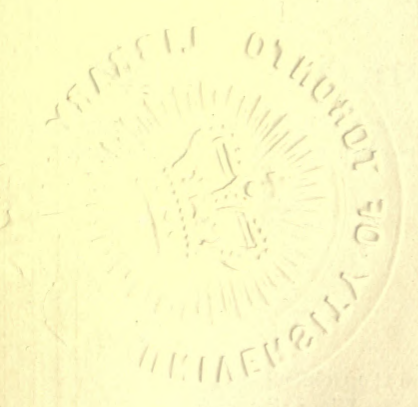

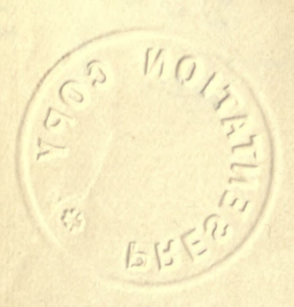




\section{PUBLISHERS' NOTE}

So much attention is now given to the practical and systematic study of science in schools that the valuable influence of descriptive scientific literature is apt to be overlooked. An intimate knowledge of the simplest fact in Nature can be obtained only by personal observation or experiment in the open air or the laboratory, but broad views of scientific thought and progress are secured best from books in which the methods and results of investigation are stated in language which is simple without being childish.

Books intended to promote interest in science must differ completely from laboratory guides, textbooks, or works of reference. They should aim at exalting the scientific spirit which leads men to devote their lives to the advancement of natural knowledge, and at showing how the human race eventually reaps the benefit of such research. Inspiration rather than information should be the keynote; and the execution should awaken in the 
reader not only appreciation of the scientific method of study and spirit of self-sacrifice, but also a desire to emulate the lives of men whose labours have brought the knowledge of Nature to its present position.

These are the objects of the series of Readable Books in Natural Knowledge to which the present volume belongs. Each volume will endeavour to stimulate interest in the studies with which it is concerned and to present natural phenomena and laws broadly and attractively. It is hoped that the books will provide the reading matter urgently required in connection with the science work in schools, and will appeal also to a wide circle of other readers. The series should be of service in directing attention to the nobility of scientific ideals and the ultimate value of results obtained by careful and faithful work. 


\section{CONTENTS}

CHAP.

PAGE

1. Primitive Tillers of the Grodnd . . 1

2. Reclaiming the Desert . . . . . 13

3. Some Contrasts . . . . . . 27

4. The Beginnings of Agriculture . . . 37

5. The Spreading of Food-Plants . . . 50

6. The Spreading of Food-Plants (continued). 63

7. Overcoming Difficulties-The Date and THE FIG. . . . . . . . 76

8. Introducing Dates into North America . 89

9. The Story of the Smyrna Fig. . . 102

10. Food and Food-Plants . . . 115

11. The Chief Kinds of Food-Plants . 127

12. Improving Cultivated Plants . $\cdot \quad 140$

13. Experiments in Plant-Breeding. . 152 
viii TILLERS OF THE GROUND

CHAP.

PAGE

14. Making New Plants . . . . . 165

15. The Struggle with Disease . . . 178

16. The Story of Rust in Wheat . . 190

17. Plant Food and the Utilisation of the Soil 200

18. The Gains that Knowledge has Brought . 212 


\section{CHAPTER I}

PRIMITIVE TILLERS OF THE GROUND

FAR away across the seas, in the great islandcontinent of Australia, there once lived many tribes of natives. It was in the days before the white man had reached the country, and there were vast spaces over which these scattered tribes might roam without coming into contact with each other. But when the white man came and established his great sheep-farms, and put up his fences and his homesteads, the space over which the natives might wander became smaller and smaller. There are not a great many natives left now, and their ways and habits have altered greatly since the old days. But many people have been greatly interested in their past history, and have asked how in a continent which over a large part is so bare, so rainless, and has so few useful plants as Australia, they ever managed to live. 
For, when first discovered, in all that great continent not one cultivated plant was known. No fields of wheat or oats waved in the wind, no orchard of fruit-trees existed; there were no domesticated animals (except the $\mathrm{dog}$ ), and no fields of turnips or mangolds, no pastures, no one of the-everyday things of our life. What did the natives eat, and how did they get enough to live upon? Many people have asked these questions, and partly by studying what was written by the first white men to come in contact with the natives, partly by watching them in those parts where they still live almost the same life as in old days, partly by asking questions, especially of the old women of the tribe; in all these ways they have found out a great deal about the natives.

We know that the men were clever hunters, and that the natives would eat almost any kind of animal food, and we know that it was the duty of the women to find vegetable food. How did they do it? Australia has hardly given one useful food plant to the world, so that the women's work was certainly not easy. They had pointed sticks called digging-sticks, and with these they dug up roots, especially wild yams; they gathered seeds, especially acacia seeds, which were used like peas and beans; they plucked leaves, which could be used as some people in Europe still use nettle and dandelion 
leaves. Like country children here, then, they had learnt to distinguish between the things which ean be eaten by hungry people and those which cannot.

What else did they know? It would seem very little. They knew that it was not wise to root up all the yams of a district, to pluck all the seed-pods of a bush, for that would mean that in other years they might get no more. Therefore, they wandered about from place to place, never completely exhausting a neighbourhood, and allowing time for the plants to grow again before they came back.

The natives knew also that there was a difference in the times of the year when the different kinds of food were ready. We perhaps know a wood where the wild strawberries are ripe in June, and when the calendar on the wall marks June we say: "Next Saturday we will go to that wood to seek for strawberries." But the Australian natives had no calendar. They had to watch the sun, to say to themselves: "When the sun is very high in the heavens at mid-day we get such and such seeds; as the mid-day sun gets lower it is time to search for such and such roots." But at best it was a hard and cruel life. It is true that there is no winter in Australia like our winter, but still think of a country where there were no barns because there was nothing to put in barns; think what would 
happen to us if we had to live upon wild strawberries, wild crab-apples, sloes, acorns, beech-nuts, and the other wild fruits and nuts of Britain.

When we take our leave then of the old Australian woman sitting huddled in her Government blanket in her Government hut, we may think with sympathy of the hard life led by her grandmother and mother, but with our sympathy we must mingle a little admiration. Her ancestors had learnt two facts which our ancestors had also to learn, two facts without which our life would be impossible. Those ancestors had learnt something about the way plants grow,- - that was the beginning of what the botanist calls plant physiology; they had learnt also that the life of plants changes with the seasons-till that lesson was learnt man could neither sow nor reap.

Let us travel far away from Australia, cross another sea, till we come to the forest lands of Bengal, near the great Brahmaputra river. Here in the dense jungles we may come upon a simple people, which seem like living fossils amid the civilisation of the East. These Korwas, as they are called, live in little clearings of the forest. They make huts of branches of the trees, and the men hunt all sorts of animals in the forest as the Australians hunt in the bush. In the same way the women collect roots, fruits, seeds, and leaves, 
which is easier here, because the jungle is full of things which they at least think eatable. But they are cleverer than the Australian women; they have learnt something which the Australians never learnt. Round the huts there is a clearing. In that clearing the women sow food-plants. These are tended with care, and the produce gathered to form a store, something to be at hand if the men's hunting fails, and the women cannot find enough food in the jungle.

The Korwas have, therefore, learnt a great lesson compared with the Australians; they know that plants will grow better if they are carefully tended and the soil kept free from weeds, but they do not know that when they harvest their crops they are taking away from the soil something which ought to be given back. They have learnt by experience that after a few years the crops get poorer and poorer, but they have never learnt why. After a few years, therefore, they move their camp, leave their clearing, and depart to a little distance where a fresh clearing may be made and crops sown on unexhausted soil, where they may find fresh fruits in the jungle, and the men fresh animals to hunt. We find almost the same kind of life among the little, dark-skinned mountain people in the Philippine Islands; it was probably once common in many parts of the globe. 
Let us take another journey across the seas, and we find ourselves among a people who have learnt a great deal as compared with the poor Australians, or the little, dark mountain people of the Philippines. The latter, we are told, are always hungry, and spend their whole lives in a ceaseless search for enough to eat. This time we stop to look at a people who are for the most part fat and well-fed. It is Uganda, and the people are woolly-haired negroes. They have cattle, sheep, goats, fowls, and dogs as domestic animals, though not a great many of these. They are thus far better off than the poor, wandering Australians. Instead of getting meat only when they can kill wild animals, they can, especially the chiefs and rich people, kill their cattle, goats, and sheep for food; they also get eggs from their fowls, and fish from the rivers and lakes. They eat locusts and white ants, of which they are very fond, and their country produces several kinds of edible mushrooms as well as a good many fruits, seeds, and roots, which are all used as food.

But this is not nearly enough; all the things we have mentioned are, as it were, extras and additions. Some of these things, like meat, can only be got on special occasions, because the Baganda, as these people are called, are not clever at cattle-raising, and, therefore, cannot afford to kill their cattle, except very occasionally. Just as 


\section{PRIMITIVE TILLERS OF THE GROUND 7}

bread is the most important part of our food-so that we speak of "our daily bread" when we mean food-so the banana forms the most important part of their food. One of the missionaries tells us that when the natives were told that bananas do not grow in England, they said at once: "Then you have come to our country to get our bananas." They could not think of life without bananas any more than we could think of life without bread. The banana is almost everything to them. They eat the fruit, either raw or cooked; they use the leaves to wrap the fruit in while it is being cooked, and for many other purposes; they use the stem as manure and also the soft inside part as sponge and soap combined. There is no end to the uses to which the plant may be put.

How do they get their bananas? The answer is that they grow them in vast plantations or groves, the plantations having to be looked after very carefully. Where the banana came from originally is a more difficult question. Some bananas grow wild in Africa, and it is possible that long, long ago some wise person began to cultivate the wild banana, and took such good care of it in his garden that it lost its seeds and became the plump, seedless, nourishing banana of to-day. It is more likely, however, that it was not in Africa but in Asia that the banana was first 
cultivated, and that from Asia it spread to Africa. In the wonderful East, we know, many cultivated plants were produced, so that the people there became numerous, flourishing, and civilised during

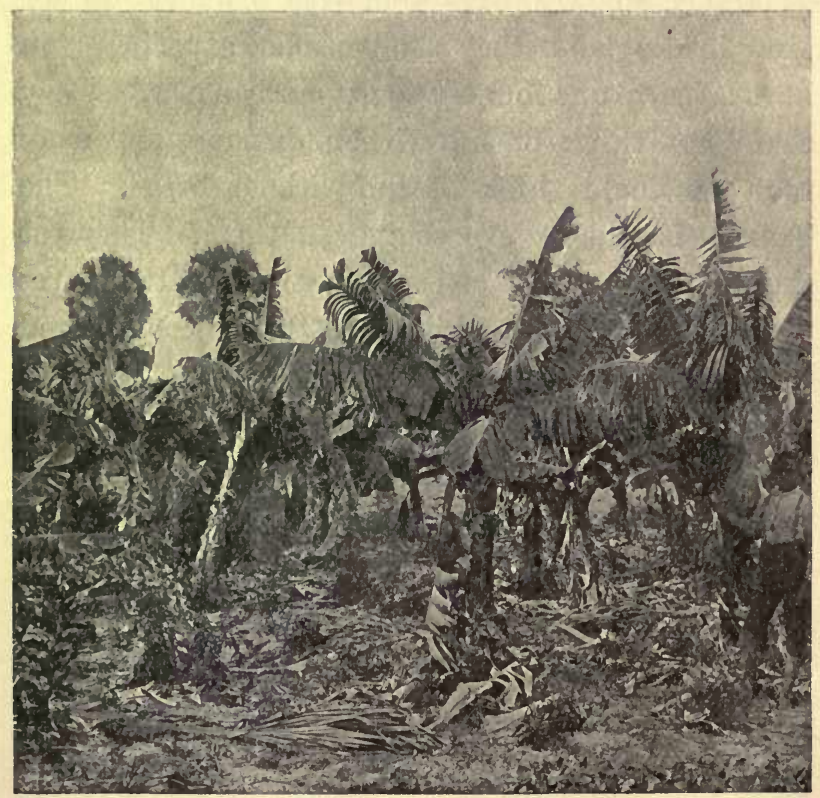

Fig. 1.-A Banana Plantation.

the long centuries that the Australian woman was striving with her foolish digging-stick to root up the almost useless yams from the barren soil, without ever thinking of trying to grow them for herself. 
Either from his forest, then, or more likely from the East, the African negro got his banana. If it came to him from the East as a cultivated plant, then probably it was something like the fruit we know; that is, it had a thick pulp, and in the centre never more than a last remnant of seeds. Next time we eat bananas let us look for these last remains of seeds in the centre. They are worth looking at. The wild kinds of bananas that grow in the forests have large, bitter seeds, real seeds, not the little specks we see in our bananas, and round those bitter seeds there is a very little tasteless pulp. Long generations of men (or more likely of women) must have cultivated this wild banana patiently, and with very little result, before the banana of to-day was produced.

The banana has no seeds; how then can a new plantation be made? In this way: A banana plant has a huge stem crowned with enormous leaves; each stem only produces one "bunch," and is cut down as the fruit is ready. But just as we may see shoots springing up round the base of a tree which has been cut down, so new stems spring up round the base of the banana stem. It is these shoots which are taken to make new plantations, and about eighteen months after they have been put in they will each produce a bunch of bananas in their turn. But remember what a bunch means 
here-each one may weigh half-a-hundredweight, and contain many hundreds of bananas.

There are many kinds of bananas in Uganda, but these fall into two sets-those which are sweet and nice when they are ripe, and those which are not nice when ripe; the latter are often called plantains.

The sweet bananas are eaten as fruit and are largely used to make beer, but the plantains are used cooked, and are eaten before they are ripe. They are then not sweet at all, but starchy like a potato. The plantains are peeled, and are then wrapped in leaves and steamed over a pot of water much as we steam potatoes. Like potatoes they have not a great deal of taste, and therefore the natives eat various kinds of sauces with them. What they like best is a sauce made of meat or fish, but if they cannot get this they must be content with a spicy vegetable sauce, a little curry, or even nothing but a little salt.

Sir Harry Johnston gives a very amusing account of the meals. The cooked plantain pulp is mashed up as we mash potatoes, and is spread out on a plantain leaf on the ground. Nobody has knife or fork or spoon, but everybody must wash his or her hands before beginning. As there isn't a tap, one person pours the water out of a pitcher in a thin stream, while the other persons wash their fingers 


\section{PRIMITIVE TILLERS OF THE GROUND 11}

beneath. Then everybody sits in a ring round the

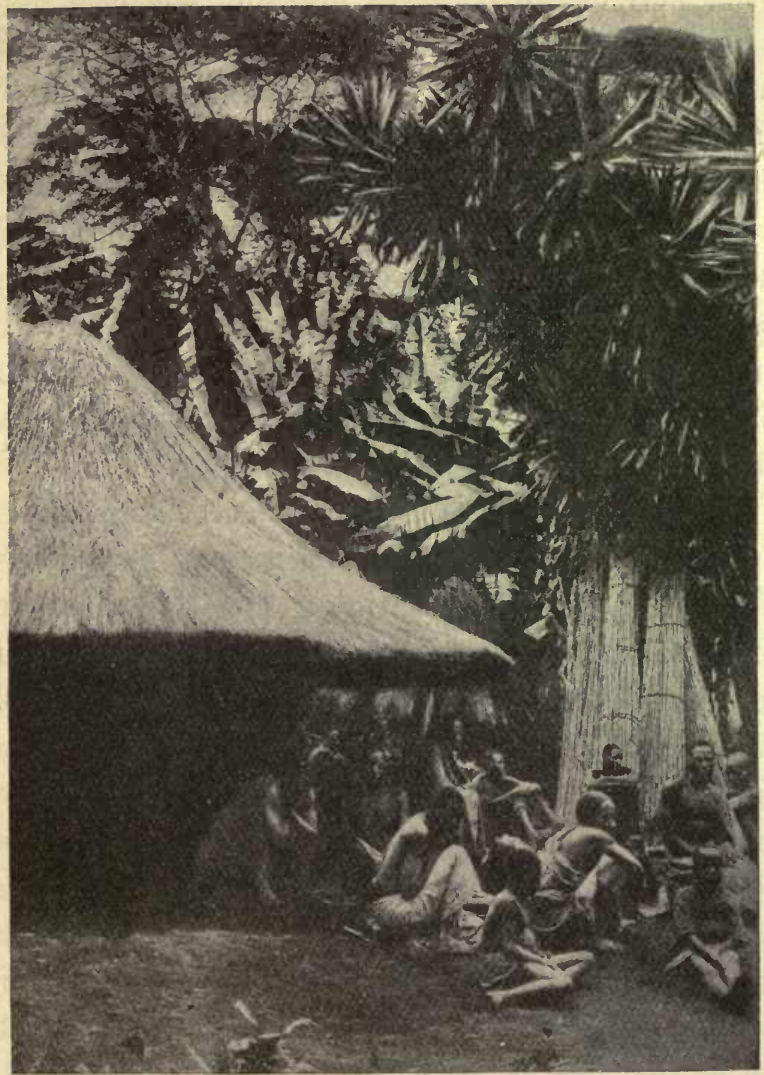

FIG. 2.-A Native Hut in the African Forest.

steaming mass of mashed plantain. Beside it stands the small dish with the precious sauce, perhaps 
made by boiling small pieces of meat in water. Everybody dips his fingers into the hot food, and makes a little ball in his hand, then this ball is quickly dipped into the gravy and transferred to the mouth. This requires some skill, because it is an unpardonable sin to let any drops of the precious gravy fall to the ground. The children especially cannot learn just at once to eat without spilling something, and then they are severely reproved by their elders. There is, perhaps, not so much difference between them and us as we might think at first sight.

But we must go back to the banana grove. Once it has been made by setting out new stocks it requires careful attention. The soil must be kept free from weeds, and that is not easy in a hot, damp country where everything grows so fast. Partly to help to keep down the weeds, and partly as manure, the stems, as they are cut down, are spread upon the ground round the roots of the trees. If looked after in this way, and if extra shoots which are not wanted are taken away, the banana fruits abundantly and fruits all the year round. This is a very important point, because it means that the people do not need to be provident. They do not need to lay up stores for a season of scarcity, because there is fruit in their plantations at all times. This is, no doubt, one of the reasons 
why they cultivate so few other plants. No other plant will produce so freely, and no other plant will produce all the year round-why should they trouble with others? The result is that, when at long intervals there is not rain enough for the banana, then the people are near starvation at once; they have nothing to fall back upon.

\section{CHAPTER II}

\section{RECLAIMING THE DESERT}

We have seen how, near the equator in Africa, with everything in their favour, the natives of Uganda can practically produce one food-plant only, and that they do in the most wasteful and ineffective fashion possible. Nature does almost everything for them; they are content with the food that can be obtained with the minimum of effort, and have never tried to learn better methods. As a contrast with their ways let us look at what is being done in the Far West of North America, in the hot, dry regions beyond the Rocky Mountains, where nature does less and man must needs do more. He has succeeded in doing some wonderful things. Let us 
look first at what he has done, and then try to find out how he has done it.

Let us go very far west to the State of Arizona, which has been called "The Land that God Forgot." It is the State which contains the wonderful Canyon of Colorado and some perhaps eren more

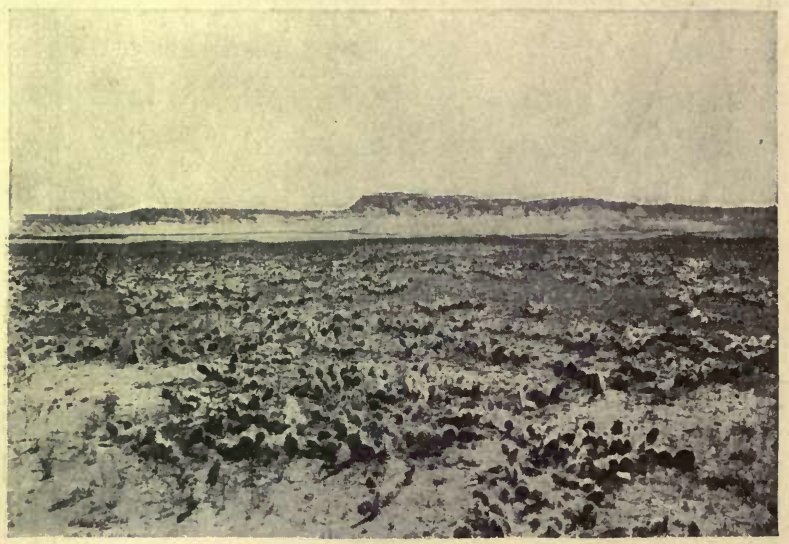

FIG. 3.-View in the American Desert.

wonderful antiquities. On the sides of the great cliffs there are remnants of the houses and the palaces of a vanished people, a people of whom we know almost nothing. Wonderful palaces they are, almost like the buildings of ancient Egypt in their evidences of infinite toil and patience. But a great part of the country consists of dreary desert wastes. How did that ancient people live while 
they were constructing their huge palaces, one of which we are told contains thirty million pieces of stone, each one of which must have been quarried, and carried up steep ladders in a basket by labourers before it could be placed in position?

Part, at least, of the answer is given in the miles of old choked canals, which can still be traced throughout whole valleys, and which once doubtless carried the precious water to acres and acres of cultivated land, where Indian corn, beans, and "squashes" grew and flourished. The land is desert for want of water. The rain that falls is fast sucked up by the blazing sun, sucked up before the plants can satisfy their needs, and therefore only a few hardy plants can grow naturally. But what the vanished Indians did on a limited scale the energetic Americans are doing on a big scale; they are carrying their canals and their roads all over the country, and where the engineer has passed with his water there orchards blossom, there fields of grain and of fruit spring up.

There is a pretty story about St. Zenobius of Florence which tells how, when his body was borne to the Church of San Salvatore in mid-January, the press of the crowd was so great that the bearers fell, and the body of the saint touched an elm standing bare and naked under the winter sky. Forthwith the elm produced leaves and 
of moisture; they do not grow much, but, like gorse, they often have a wealth of flowers, and they have a great development of roots. For instance, in the Arizona desert there is a plant related to the acacia, called mesquite by the Spaniards, which in the desert is never more than a few feet high, but may have roots 50 feet long. These roots are used for fuel, and the people say that Arizona is topsy-turvy land, for they have to dig for wood and climb for water-the only drinkable water being in the pools on the tops of the hills.

There are other acacia-like plants, such as one which is called cat's claw-a suggestive name when we think how common spines are in desert plants. But the most curious plants of the desert are the cactuses. There are giant " candle" cactuses, which grow stiffly up in the air, in some places reaching a height of 45 feet, and have a few pokery branches. One of these candle cactuses has such prickly fruits that the natives use them as hair brushes. Then there are the barrel cactuses, shaped just like a barrel, and very convenient for thirsty travellers. They grow to a height of 5 feet, and the Indians cut off the top as one might take the top off a huge egg. The inside is pulpy and full of water. The native takes a stake and pounds this soft pulp, then squeezes it to get all the fluid out, digs out the squeezed pulp, and in 
this way produces inside the eactus barrel a large amount of watery fluid, which he finds very good, for desert travellers must not be too particular. Then we have giant yuccas, the creosote plant, the name of which suggests its taste, and acres and acres of sage-brush, which is a plant related to our wormwood. There are rushes and grasses, too, something like the sand-reed of our dunes, and many other peculiar plants.

One other curious feature about the desert we must also mention; this is that in many places there are great deposits of salt on the surface and also of "alkalis," that is, chemical substances like washingsoda. It is this which makes the water so bitter and so unwholesome for man and beast, and it is because only some plants can bear salt and alkali that the desert plants have such strange forms. Our ordinary everyday plants cannot tolerate them at all, as we should soon find if we watered our gardens with washing-soda dissolved in water.

Sand, alkali, and eactuses, then, these are the three great features of the desert. No water to drink, no grass for the animals - it does not sound very hopeful, does it? But our American cousins have courage. Here is a picture (Fig. 5) - made from a photograph, remember - of a courageous party building a house in the middle of the desert. We can see the sand, the desert plants, and we can easily 
imagine the hot sun, the salt, the want of water. We might even imagine the ugly horned toad that lives in those wastes grinning at the arrant folly of mankind imagining that he can make a living in that dreary country. Perhaps he even discusses

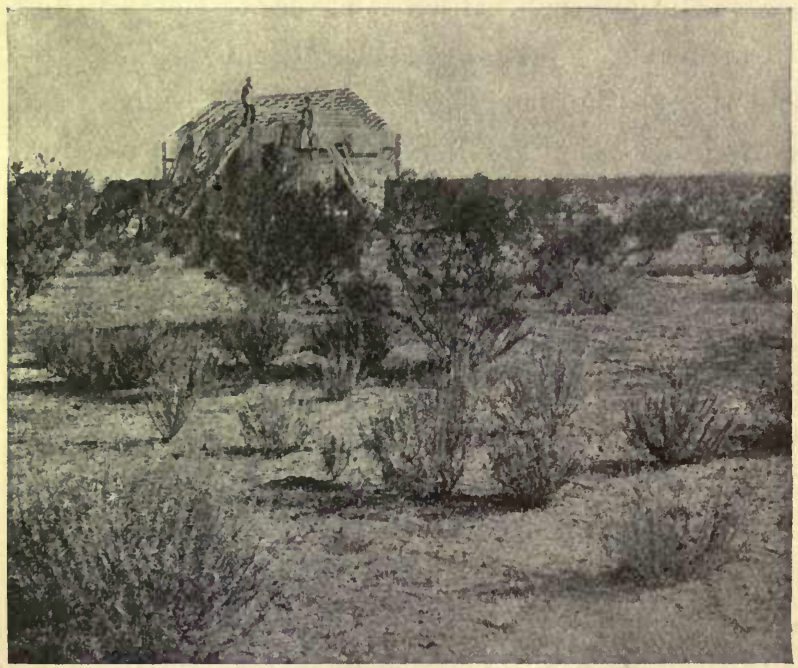

FIG. 5.-Building a House in the Desert in anticipation of Water.

the question with his friend the poisonous lizard, another ugly creature found in the region.

But wait a bit and we shall see if the laugh is with man or the toad. Look at the other pictures (Figs. 6, 13). "Give me water," says the man, "and my cattle shall stand knee-deep in luxuriant fodder where now you sun yourself in the sand. My orange 
trees shall drop oranges more golden than the stripes on the back of your friend the lizard, thicker on the trees than the ugly spines on your body. My peach trees shall be weighed down with their weight of fruit. The Indians, who are struggling desperately to grow a few grains of maize round the damp places in the sand, will flock to help me to bring in my harvest. Dates shall grow on my land as they never grew in Egypt; grapes as they never grew in Spain; there shall be acres of melons and pumpkins, even the humble cabbage will grow so as to give me five crops in the year." Something of this kind he would say to us if he were not too busy building his house and getting his seeds and his implements to say much at all. It is at least what might be said for him.

But, some one will perhaps say, this is not our prosaic earth, this is the Garden of Eden. Peaches, oranges, grapes, dates, almonds, melons, growing as we never imagined they could grow-why does not the whole world go out to Arizona to sit in peace and comfort beneath its own vine and fig tree? Well, like most things, it is not so simple as it seems. So far from simple is it that the United States Government does its best to discourage people going out to those distant lands unless they have both eapital and skill. Capital, that means the power to wait, the power which 


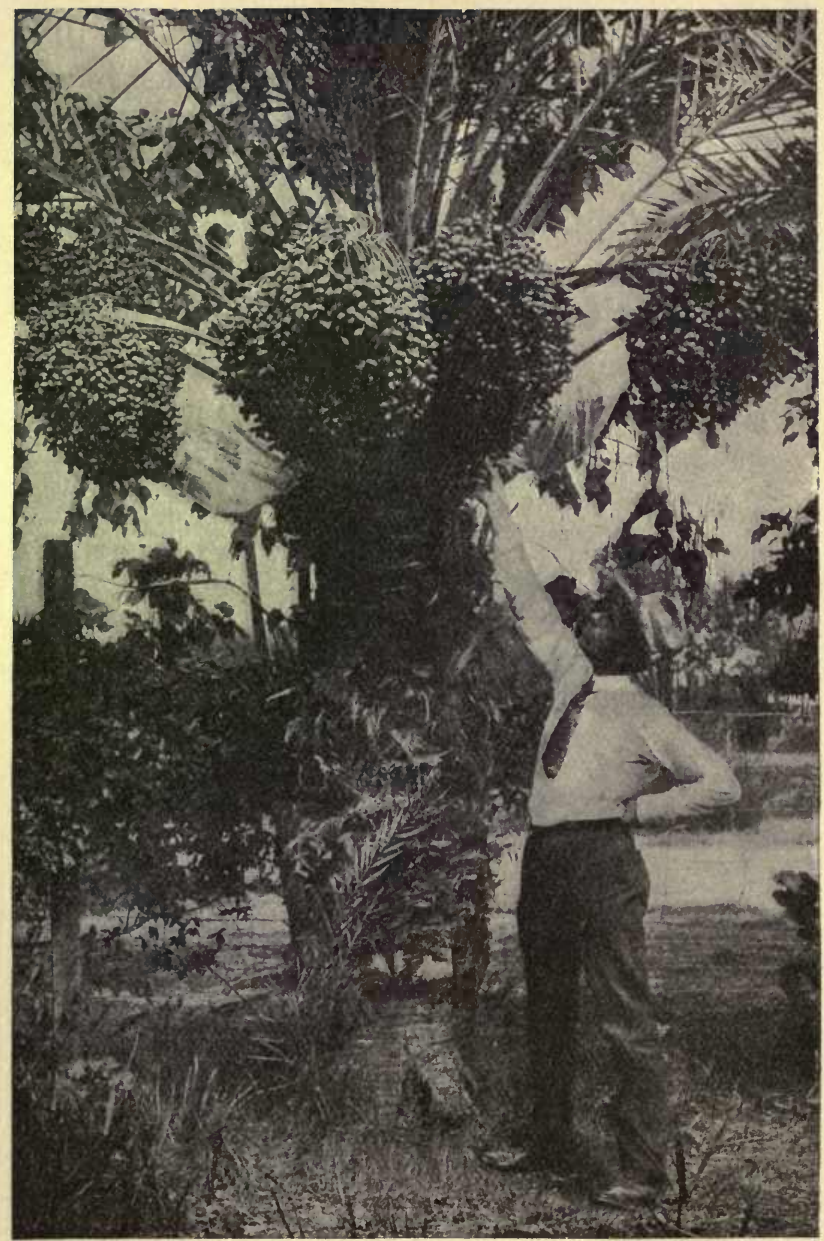

Fig. 6.-Date Tree in Fruit in Salt River Valley. 
the African negro has not. Before a vine or a peach tree can be planted, the water must be brought, and to bring the water means continuous, costly toil.

It is true that the farmer does not come until the water has been brought, but he must pay his share of the expense. His acres of melons have to be watered before a single fruit appears, and that water he must pay for. There are many other things besides the water, however, which he must have before he can gather a fruit. He must have labour, he must have implements, he must have seeds and trees, he must have food and clothing and shelter while his crops are growing. $\mathrm{He}$ is going to get more from his land than the African negro, but he must take more to it.

But it is not enough for him to have capital, that is, the power to wait; he must have skill, and that largely means he must know how to make use of the knowledge and experience of bygone generations and of his own generation. The African negroes have but little to tell their children; and as those children learn but little for themselves, there is very little progress. But in America each generation must so make use of the learning of the generations that went before as to be able to advance beyond them, must be able to add something to the sum of knowledge which 
they can hand on to their children-there, to stand

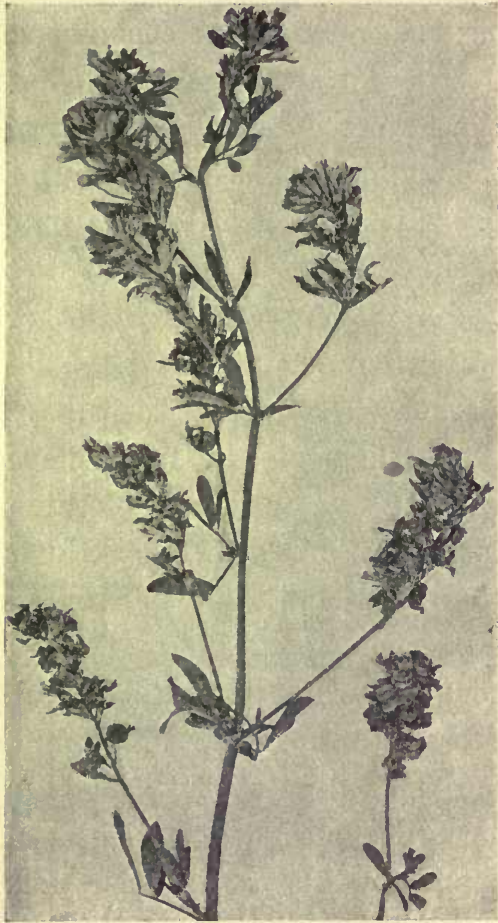

Fig. 7.-Alfalfa. still is to go back. Let us go back to the watered land in Arizona, and see why skill is necessary. The wonderful fruits that the watered land grows have been mentioned especially, because such remarkable crops of fruit always seem to us to mean wealth untold; but really the fruit-crops, though the most conspicuous, are not the most important. We shall find that it is often so, that the very striking things are not always very important, and that wisdom often means the power to see the real importance of things that seem trivial The apparently trivial thing in this case is a fodder plant called lucerne, 
or alfalfa, to call it by its pretty Spanish name. We spoke a moment ago of the cattle standing knee-deep in the fields, but it is not in fields of grass but of alfalfa that they stand.

Alfalfa is a little like a clover, but more like the little medick of our fields. It has a bluish flower, and is a plant which we do not very often see in this country, partly because ours is a rainy country. On the continent of Europe, however, it is very commonly grown, especially in the dry, hot south, and notably in Spain. Curiously enough, however, it did not reach Western North America directly from Spain or even from Europe. The Spanish missionaries took it with them to South America, to Chile, and from there it was brought by other Spanish missionaries to California. It was only in the middle of the nineteenth century that they brought it to California, but it was a great gift, for it is said that now two million acres of alfalfa grow in the west of North America.

Like so many other valuable plants, alfalfa seems to have come originally from the region of Persia and Asia Minor. Now, in that region the inhabitants had had to struggle for untold generations against nearly the same difficulties as in Western America-that is, against drought and alkali. By prolonged care, and many experiments, they succeeded in growing kinds of alfalfa which 
short time in the same plantation, and then calmly abandons that plantation and makes another.

Not all African negroes live on bananas; here, for instance, is an interesting description from a French author and traveller, Pierre Loti, of the life

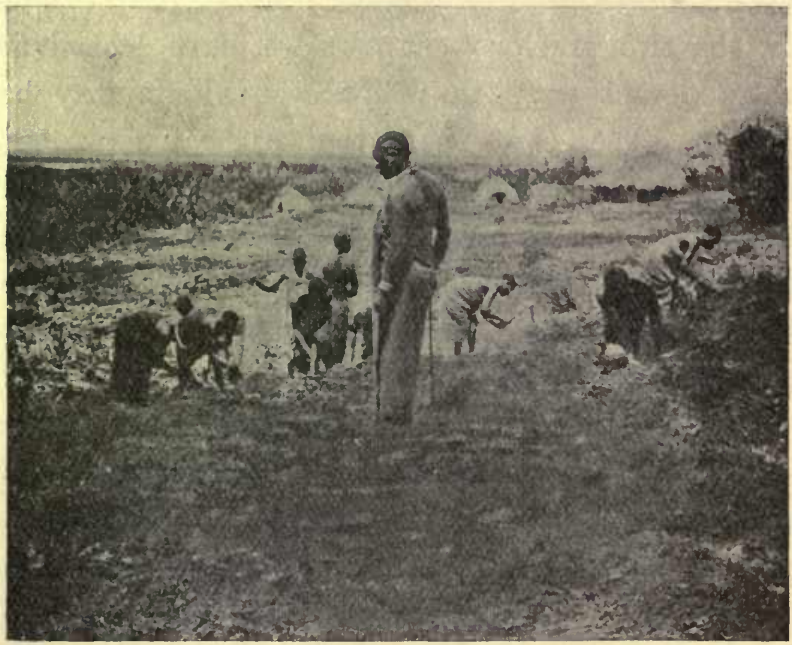

FIG. 8. -Women working in a Plantation in Africa.

of the women in the region where the little grain called millet is the chief food-stuff:-

"It is upon the women that the severest labour of the natives falls, that of pounding the millet for the kusskuss. From morning till night, throughout the whole of Nubia from Timbuctu to the coast of Guinea, in all the villages of reed and straw, 
under a consuming sun, the wooden pestles of the negresses fall noisily in their mahogany mortars. Thousands of bracelet-encircled arms are worn out in this toil, and the talkative and quarrelsome workers mingle with this monotonous sound the chorus of their high-pitched voices, which seem as if they issued from the throats of monkeys. The result is very characteristic din, which, heard from afar, in the thickets and in the desert, announces the proximity of these African villages. The product of this eternal pounding, which wears out generations of women, is a coarse millet flour, which is made into a tasteless kind of porridge, called kusskuss. It is this kusskuss which is the basal article of diet among the black races."

Some other tribes again live chiefly on yams, and so on, but generally each tribe has one special foodplant, and except where they have been taught by Europeans, they do not plough, they do not manure, they have no rotation of crops. They grow food, that is, in the most extravagant way possible. Now this has been going on for countless ages. There is reason to believe that a great part of Africa which has now no trees, was once forest-covered, and has had its forests destroyed by the natives. In spite of the climate and the fertile soil the natives are few in number, and in many cases have moved in historic times from one part of 
the country to another because they have destroyed the fertility in one place, and can grow no more food.

In the tropical parts of Africa, then, people are

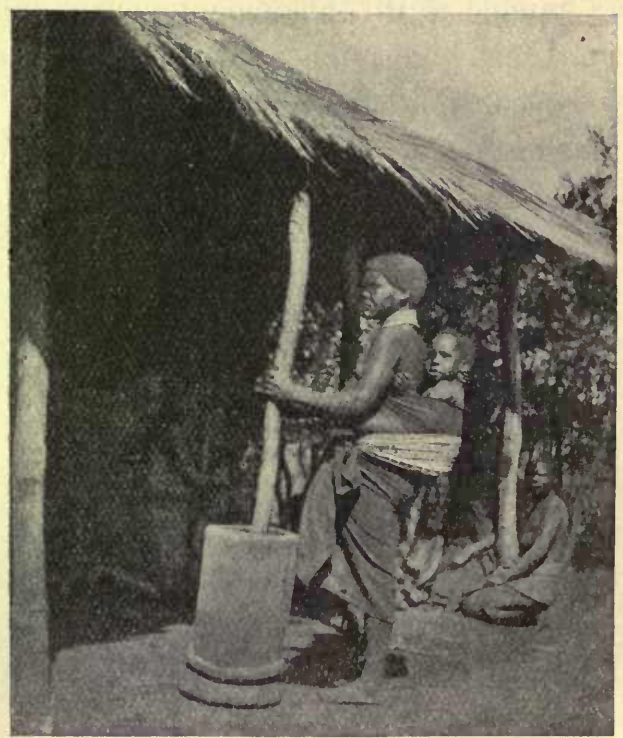

Frg. 9.-African Woman pounding "Mealies" or Indian Corn for Food.

few in number; they do not increase fast though the land is so rich, and one reason for this is that they do not know how to make a right use of their land. They have had to wait for more civilised people to teach them that.

In all the cases which we have looked at, in the 
case of the Australians, in that of the primitive tribes of India and of the Philippines, in that of the African negroes, there must be very few people spread over a great area of land. That is, the land must be scantily populated. In Africa all through the ages there have been far more people in the Nile valley than anywhere else in the vast continent. It has been, as we say, the most densely peopled part. One reason for this has always been that the people who lived there, the ancient Egyptians and the Egyptians of to-day, have been clever farmers; they have known how to get the best out of the land, and the land has therefore produced food abundantly for them and for their children.

As we shall see later, it was in the land round about the eastern end of the Mediterranean that humanity learnt the greatest of its lessons in plant-growing. It was that eastern end of the great sea which was the great school of agriculture, or one of the schools, we should perhaps say, for the Far East was another great school. There are very few of our common food-plants which are not the result of the toil of unknown generations of people in those two regions of the world. They made our food-plants; they learnt to grow them, they learnt the principles that we have to apply and extend. 
Perhaps "lesson" is not a good word to use, for we are apt to think of a lesson as something rather dull and useless, and what these ancient peoples learnt was to grow our daily bread, to get the utmost out of the smallest patch of land. The great things about food-growing, then, were learnt round the Mediterranean basin, and in the Far East, but some lessons were learnt elsewhere. We know that long before the white man came to America, either North or South, those countries were inhabited by Indians, who knew far more about plants than the African negroes, for instance.

We spoke in the last chapter of the great canals which some of those ancient peoples constructed, and also of their chief food-plants, which were maize, or Indian corn, native beans and different kinds of squashes and pumpkins. Not only had they a greater variety of plants than the African negroes, who generally have only one, but they had some cleverness in growing them. Just as in the countries round the Mediterranean, the people here had in many places to struggle desperately against want of water, and, just as in the Mediterranean region, the struggle made them clever and ingenious, for it is quite often true that we learn more when we work against big difficulties than when everything is smooth and easy.

The wisest and cleverest of these bygone 
American peoples struggled against drought by irrigation on the big scale. Those people are dead and gone ages ago, but they made their canals so wisely that when the Reclamation Service of the United States began to try to bring water to these desert lands, they sometimes simply followed the lines of those ancient canals. They had no iron and no steel, those ancient peoples; their implements were all of stone. They had no elaborate surveying instruments such as our engineers have; they had no blasting powder to help them to cut through the rocks, and yet they managed to make such wonderful canals that the modern engineer sometimes finds it best just to follow the line so marked out.

Not all the Indians were so clever, however; some of them had to be content with simpler ways of food-growing than that of elaborate schemes of irrigation. One group that we know of " scoured the Sonoran plains for chance water-holes, as well as more permanent waters, carrying religiously hoarded seeds; they chased rainstorms seen from commanding peaks for scores if not hundreds of miles; and wherever they found standing or running water, or even damp soil, they planted their seeds, guarded and cultivated the growing plants with infinite patience, and after carefully harvesting the crop, planted some of the finest 
by constant growing of crops. This is very important because it means that such people form permanent settlements, whereas primitive people have to be more or less wandering in habit, and that makes wars and bloodshed and loss of life.

Finally, the people who have these great advantages-many food-plants, a knowledge of the need for ploughing, and for a rotation of crops, and for manuring-get from these the further advantage that they can initiate improvements, that they can alter their methods with changing conditions. It was from those Mediterranean peoples of which we have spoken so often that we learnt farming. The skill that transformed Egypt and Babylonia and the other hot countries also transformed Britain from a district of dense, unhealthy marsh and forest to a country covered with smiling corn-fields and well-kept meadows; it multiplied the population a thousandfold; it led to the replacement of tribes of half-naked savages by civilised and educated people. But it has done more than this.

With all the British farmer's skill, the land is too small to grow food for all; some of the population must go elsewhere. From this little island people have gone out to Canada, to the United States, to Australia, to New Zealand, to India, to the Argentine, almost all over the globe, and 
wherever they have gone they have been able to change their methods to suit the new conditions; they have succeeded in doing what the natives of those countries could not or did not do.

The man whom we saw building his house in the desert of Arizona is perhaps the son of an Englishman, perhaps a Norwegian, perhaps a Swede; at least, either he or his fathers have probably come from Northern or Central Europe. Yet he will soon learn to grow strange plants which perhaps his fathers never saw, and he will grow them as well as the people who have been growing them for countless generations. This is what we mean by the power of adaptation, and that is a power which only comes with skill and knowledge. It is the power which the poor Australian had not, and it is the want of it which is causing him to die out.

\section{CHAPTER IV}

THE BEGINNINGS OF AGRICULTURE

THE other day a little boy was given a piece of ground for a garden. He was full of plans as to the future, and was certain that his garden would 
be not only more beautiful and interesting than the big garden, but also than any garden that had ever existed. What he specially thought of doing, he said, was to go out into the country and get beautiful plants for himself. He was not just going to sow seeds out of packets, or beg slips from the gardener; he would go out into the wide world and choose for himself the best, and bring his finds with triumph into his own little plot.

He was only seven years old, so one would not wish to discourage him, but we, who are older, know that when he has brought primroses and hyacinths and forget-me-nots from the woods, roses and honeysuckle and guelder-rose from the hedges, daisies and poppies and cornflowers from the fields, and even strawberries and rasps and wild gooseberries from the waste ground, he has only done what the gardeners have been doing for generations, and that it would have been wiser and more prudent in the long run simply to take advantage of their work, and not try to do it all over again. We know that there is not a flower or a shrub or a tree in this country which people have not tried to cultivate. We might even go further and say that there are now very few plants in the world that some one has not tried to cultivate, or at least has not made sure to be not worth cultivation.

It is possible that new and useful plants may 
still be found and cultivated, but it is not very likely. We may perhaps be inclined to laugh at the boy who thought that, during all the generations that people have had gardens in England, nobody but himself had thought of going out into the fields and woods to get roots, but many people forget that the same thing is true generally of the world at large. If we go to a new country and begin to make a garden, we may be doubtful as to what plants we ought to grow, but we shall be wiser to choose our plants out of the number of those already cultivated, rather than attempt to cultivate fresh ones.

More than this, most of the plants cultivated on the large scale, that is, most plants really useful to man, have been cultivated for a very long time, so long that they are sometimes older than history. A Swiss botanist, De Candolle, who studied the subject very carefully, says that out of the 247 cultivated plants which are most useful to man, 180 have been cultivated for more than two thousand years, and a good many of these for more than four thousand years. The most important food-plants go back into the very distant past; it was they which made it possible for man to multiply and become civilised.

The last two thousand years-and remember that these are the years which we are apt to think 
of as the most important in the history of the world, as the years in which man has learnt most - these years have only added about sixty-seven cultivated plants to the world's stock, and a good many of these are not of great importance. Choosing the useful plants was a task which man accomplished early. If any of us are interested in gardening, we may be tolerably sure before we begin that we are likely to waste a great deal of time if we are possessed with the idea that it is better to try to make fresh cultivated plants rather than to take those which have been already cultivated.

It is interesting to try to find out where the important food-plants were first cultivated. Especially from the work of De Candolle, the botanist mentioned already, we know that most of our plants originated in the eastern end of the Mediterranean basin and in the Far East. A few, but those important, originated in the warm parts of America, especially in Mexico and Peru, where the ancient people were very intelligent and civilised. Some of the most important of the American plants are maize or Indian corn, the potato, tobacco, prickly pears, gourds and pumpkins, the Jerusalem artichoke, and so on.

Great regions of the earth's surface have not produced any cultivated plants. Australia has given 
us none, nor yet the country round the Cape of Good Hope; we owe nothing to New Zealand, to South America south of the Plate river, nor to the Arctic and Antarctic regions. All the men who live in or near these regions to-day are dependent for their food on the skill, the patience, and the intelligence of the dead and gone folk who lived in the three regions mentioned already. We should think of that sometimes when we are inclined to speak contemptuously of, for instance, the yellowskinned Chinese, who have done a large share of the world's work.

Why were the people in these three regions wiser and more patient than their neighbours? How did they manage to do what the others could not do? Well, we can hardly give the whole answer, but there are a good many points that are worth noticing. We can find partial explanations in the climate and character of the country, in the nature of the indigenous (that is, native) plants, and in the nature of the people. For instance, we cannot blame the Eskimo for not having any cultivated plants, for their country produces very few plants at all, and their climate will not grow them. More than that, when the climate is very cold people must have much animal food and a large quantity of fat; so that food-plants are of less use to them than to dwellers in warm countries. 
Wherever man learnt first to grow plants, then, it must have been in a region of moderate climate.

There must be an insufficiency of animal food, or the climate must be so hot that much animal food is not wanted. In the latter case the wild plants must not be sufficient to produce food for everybody. "When men can live without work," says De Candolle, "it is what they like best. Besides, the element of hazard in hunting and fishing attracts primitive and sometimes civilised man more than the rude and regular labour of cultivation." We may suppose, perhaps, that agriculture would sometimes start in a country where there were productive wild plants. The people would multiply because there was good food, and then, as they increased faster than the wild foodplants, they perhaps began to cultivate these.

In the Far East, cultivation was always easy from the fact that the rains come in the warm season when the plants need water to grow. When the Chinese saw the whole country covered with growing plants in the rainy season, the idea of sowing seeds would be more likely to occur to them. Again, in Egypt the periodical overflowing of the Nile brought the water necessary for growing plants, and would help to teach the people the usefulness of sowing seeds. Afterwards, when in the course of time they had learnt that it was 
only water that was necessary to make their land fertile, the idea of bringing water, that is of irrigation, would occur to them.

Another point which must have been of great importance is that cultivated plants mostly arose north of the Equator, and botanists have shown that annual plants, that is, those which only live one year, are more common in the north than in the far south. A great many cultivated plants are annuals, which grow much faster than perennial or long-lived herbs or trees, and the idea of cultivating annuals would naturally arise early. Wheat, barley, oats, millet, rice, maize - these are only a few of the important annuals, and all these come from the more northern part of the earth's surface.

We might say also that it was because the useful plants grew naturally in the countries where agriculture began that they were cultivated, only we are not quite sure how far this is true. What is true is that the cultivated plants were developed from plants growing in the regions where agriculture started, but it is difficult to be sure that it was only in these countries that plants grew which were worth cultivating. For instance, practically no useful cultivated plant comes from Australia, but till the white man went, nobody thought of trying to cultivate plants there. We might say that when the white man went he should have 
tried to cultivate the native plants, but then we must remember that such a plant as wheat, for instance, has been cultivated for more than four thousand years. Perhaps some of the Australian grasses would be good to eat if they were cultivated for four thousand years, but it is rather long to wait! It is much wiser now to take the old cultivated plants than to try to make new ones.

We might spend a long time trying to think of the reasons why the cultivated plants all arose in the three special parts of the earth's surface, and why cultivation arose there too; but perhaps it is sufficient just to suggest the one or two reasons given above, and to go on to show that, whatever was the reason, the fact gave the people of those regions an advantage which they have never lost. This is specially true of the Mediterranean peoples and the peoples of the Far East. If we take the map of the world and look at it, we shall find that these peoples or their descendants, armed with their cultivated plants, have literally inherited the earth.

We are apt to think that it is because the European has guns that he has spread all over the globe, but it is really because he has wheat and other plants. His guns would not help him permanently without the wheat. In the same way the teeming multitudes of China and Japan are the direct result of the skill of the people in growing food; the 
Australian, the Tasmanian, the North American Indian have died out, or diminished in numbers, because they either did not cultivate at all or did not cultivate enough.

The advantages even of cultivating a few plants must have been very great from the beginning; the discovery of its possibility must have marked an epoch in the life of a people. How important it was we can gather in various ways, and especially by the connection between agriculture and religion. Religion, we know, has to do with the part of life that we recognise as the deepest and most important, with the things that cannot be questioned, because the life of the whole people depends upon them. Now among almost all peoples when we look deep enough we find a connection between agriculture and religion, sometimes a very close connection. Again, just as the religion of a people, when it is real, represents the most important part of their individual life, so, especially among a simple people, the king or chief as the head of the community is directly associated with religious ceremonies. We therefore find that among people who are successful tillers of the ground, the king is originally always the great agriculturist.

In China, for example, there is an interesting. annual ceremony where five important plants are sown by the emperor in the springtime, these being: 
rice, sweet potato, wheat, and two kinds of millet. The emperor at the same time also ploughs a portion of the sacred field. From the records of that wonderful nation we know that this ceremony goes back to two thousand seven hundred years before Christ; not so very far. short of five thousand years ago. The ceremony was started then by the Emperor Chenming, and though it means nothing now, it must have meant then that the knowledge of agriculture was so precious that it was part of religion, and was the special attribute of the emperor.

This early connection of agriculture and religion has one very interesting result. We cannot tell directly how and where agriculture began, because the beginnings were among people who did not know how to record their history. But, though they wrote nothing, they fixed their experience and their learning in their religion, in ceremonies the meaning of which their children forgot while they remembered the ceremonies. Almost every people and every race in the world, civilised and uncivilised, has such " fossil" ceremonies, the meaning of which they cannot explain. Scientific men, with infinite care and patience, have collected from all over the globe instances of these curious rites and ceremonies, and from the collections so made they have succeeded in spelling out dimly the history of 
the distant past, the history of the beginnings of agriculture.

Some of us have been in the country in harvest-

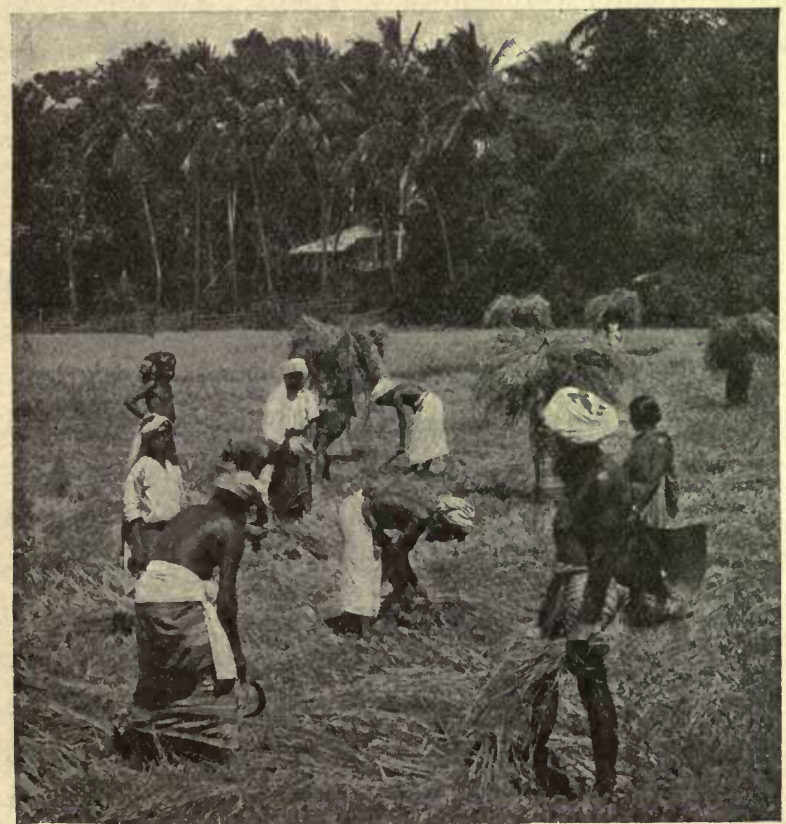

FIG. 11. - Harvesting Rice in Ceylon.

time, in a good harvest when the stackyard fills slowly with golden sheaves, and the skies are sunny through all the days of cutting and leading. As the last cart comes home, and the labourers see that their time of hard work is nearly over, 
they show their gladness in various ways. They perhaps dress up the last sheaf as a "cornmaiden," they bring it home singing and with many quaint ceremonies. There is a supper in the barn to finish up, with music and dancing and singing.

The supper, the singing, the dancing are easy to understand. If we had worked so long and so hard we should rejoice when our work was over, but what about the corn-maiden, decked with ribbons, what does that mean? It becomes even more puzzling when we find that almost everywhere, not only in many parts of England and Scotland, in Germany, in Russia, but even in parts of the world that we call uncivilised, we have much the same curious customs connected with " harvesthomes." Well, the consideration of the exact meaning of these ceremonies would take us too fur from our subject, but now it is interesting to note that they are the remains of far-distant religious rites, the object of which was to make the corn grow again next year.

The first farmers reaped their scanty crops in autumn, and they saved a few seeds, even through the days of hunger, in order that they might sow new fields in the spring. But they felt, much more than we do, that the greatest of miracles on this earth is that from a handful of dry seeds new 
fields of waving corn will grow. We have learnt much, not nearly all, but much as to how the seed grows, but for them it was the great mystery. They brought their sheaves home with gladness, but it was a fearful gladness, for they were never. sure that the miracle would repeat itself in a new spring. They were not even sure that the mid-day sun, sinking day by day in the sky, would rise again to his midsummer strength, and, therefore, with their harvest joy was mingled some fear and some sadness. They were afraid that the gods would be jealous of too much gladness, and with their songs and music and dancing they mingled some dreadful rites. They offered terrible sacrifices to the god of corn and wine, lest too much joy should rouse his wrath, lest he should refuse to send a new harvest with the coming year. What seem to us the rather foolish ceremonies of harvest-home are just the last remains of those dreadful sacrificesthe last remnant of an age-long tradition. 


\section{CHAPTER V}

THE SPREADING OF FOOD-PLANTS

WE have seen already that the last two thousand years have not added a great many to the number of food-plants known. In the Old World at least, not only was the work of selecting suitable foodplants nearly completed before this, but also the known plants were widely distributed in nearly all suitable places. America was an exception, for till its conquest by the Spaniards there does not seem to have been any interchange of plants between the Old World and the New. After its discovery not only were a few useful American plants introduced into Europe and Asia, but many useful Old World plants were introduced into America. That country indeed received far more than she gave, and this is one reason why, though the old America could barely feed her own sceanty population, the America of to-day pours a ceaseless stream of food into Europe. The Old World gave to the New out of its store of knowledge and experience in the form of useful plants, and it is every day receiving back its gift a thousandfold.

This interchange of plants between the old and 
the New Worlds was late, but it was otherwise with the plants of the Mediterranean basin and those of China. Here no great expanse of ocean separated the countries. Intercourse was comparatively easy, and though China did not formerly, and still does not, love the outside world, she was willing enough to exchange useful plants. For example, some two hundred years before Christ, that is, more than two thousand years ago, a Chinese ambassador called Chang-Kien came across the great wastes to Western Asia to observe the ways of the outside world, and he took back with him to China many useful plants. Rather a mixed lot he collected, for we learn that in his capacious box were beans and peas, cucumber and saffron, lucerne and walnuts, spinach and water-melons. A large case it must have been, that in which he brought back the fruits of his ten years' wandering, for he was in no hurry, and saw many things on his journey!

This was a big journey, but there were always merchants travelling between east and west, and it was doubtless by their help that the cultivated plants of the two regions became so mingled that it is very difficult for us now to say definitely which was first cultivated in the east and which in the west.

In early days it was much easier to introduce 
plants by land than by sea. This is shown clearly by the fact that though China and Japan are comparatively speaking so near to one another, yet communication between the two was late. Thus

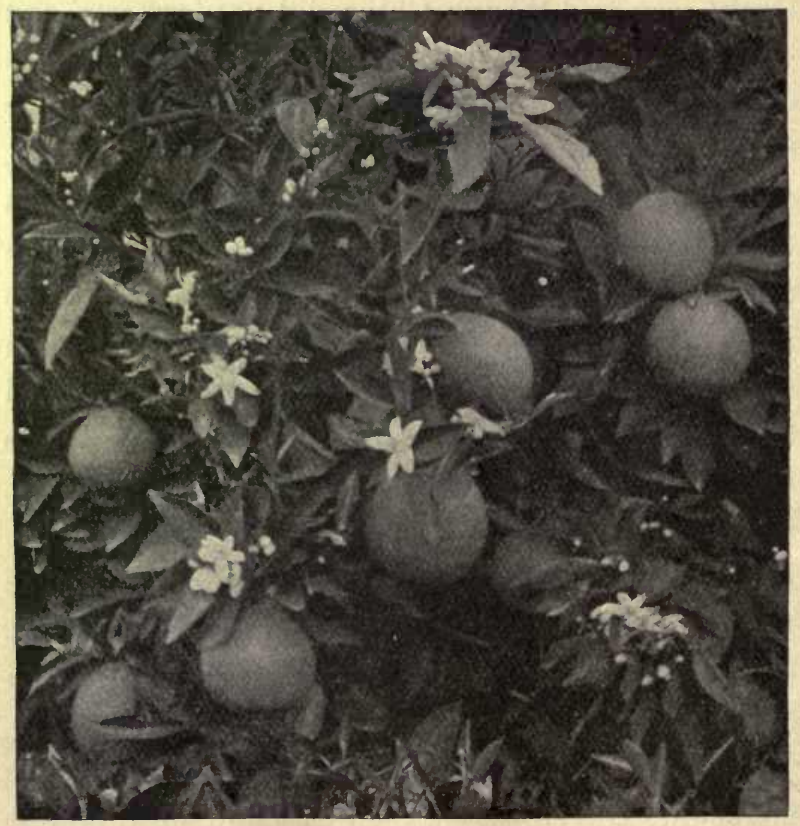

FIg. 12.-Blossom and Fruit of Orange.

the fruits called citrus, which includes the different kinds of oranges, lemons, etc., are natives of the Far East, but were introduced at an early date into Western Asia. They did not reach Japan, however, until the first century after Christ, about 
eighteen hundred years ago. There is in Japan a monument to the first Japanese who succeeded in bringing these fruits over to his own country. His name was Tajima Mori, and he was sent by the Mikado to China to bring back plants. It took him nine years to get the plants introduced, and the inscription on the monument means, "How magnificent is the result of Taji's work." Every one will agree that it was a fine piece of work - to be of use not only to our own generation, but to all the unborn generations down to the end of time; that is worth nine years of hard work and danger, isn't it?

Tajima's dust has lain for eighteen hundred years in the churchyard of Fukushoji, where this monument is erected, but his spirit lives for ever in the scent of the oranges and in their golden fruit. Let us salute the dust of Tajima, and with him the unknown, unrecorded generations of Chinese, whose labours made the sweet, luscious orange from the poor, bitter wild fruit. How magnificent, also, is the result of their work-which must have lasted not for nine years but for perhaps long generations. We may smile at the people of China and Japan because they worship their ancestors, but does not that worship partly mean simply that they are grateful for the gifts their fathers have given them? They recognise it as their duty to hand on this gift 


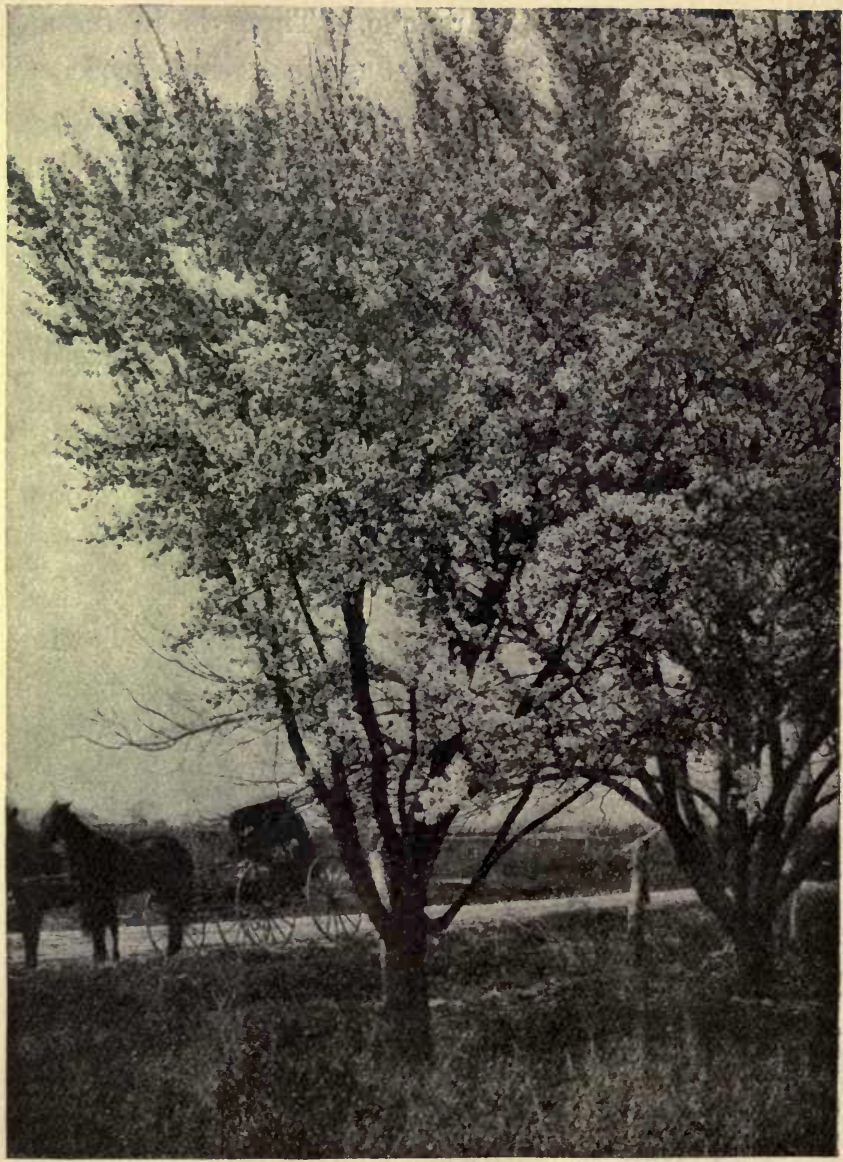

FIG. 13. - An Almond Orchard in Bloom on Irrigated Land in the United States. 
to their children, improved and made better by their toil, so that these children in their turn may have occasion to be grateful, and thus each generation may make life fuller and more secure for thenext.

The two examples just mentioned show, at least. generally, how plants were introduced from one country to another in the olden days. For the sake of the contrast let us look at the way they are introduced now. It is perhaps a quicker way, but, yet it is not easy.

In one of the early chapters we looked at the way in which orchards and gardens and fields seemed to spring out of the barren earth in Arizona, as soon as the fairy called Water touched the surface. So charming was the picture that we were seized with a desire to take boat and train at. once for Arizona, in order to find ourselves amid that apparently miraculous plenty. But we found that our ardour was a little checked by the fact. that the United States Government seemed disposed to ask all sorts of questions before they would let us begin. If your crops all fail, and your grapes and peaches refuse to grow, have you enough to. live upon until better times come? Can you grow oranges? Do you know how to fertilise figs and dates? What will you do if the boll weevil attacks your cotton? 
These were the kind of questions the Government seemed disposed to put, so we thought it wiser to wait a little while before selling all we had and starting for the great desert. In the meantime, though, while we are waiting, we may as well try to find out how the people there got their oranges and grapes and dates, and how they learnt to grow them. Men of our blood, men whose fathers grew the humble potato, turnip and cabbage, how did they learn all that they must have learnt, and where did they get their lucerne and all their wonderful fruit trees? Well, the answer is rather a long one. Let us at least look at parts of it.

We have seen that there is in the United States a body of engineers called the Reclamation Service, whose work it is to plan roads and canals, to bring water to land which is crying out for it, and to take it away from the marsh-land which is unproductive because it has too much water.

There is also another body of men, botanists and agriculturists this time, whose duty it is to find, all over the world, plants suitable for all the different soils and climates of the United States. They must first find the plants, and that is not always easy; then they must grow them, to make sure that the plants are suitable and to get enough seeds or cuttings to distribute to the farmers. Even then their work is not done, for they quite often find that, with the 
plants which they have brought from Spain or from Africa, they have brought insect pests or plant diseases. They must study these when they exist, and be able to give the farmers advice how to prevent or to cure plant disease in valuable plants. They must also know the different kinds of the same plant, for some are suitable for one climate and some for another.

The men who are busy with this work form the Bureau of Plant Industry, which includes many different kinds of workers. Some must travel all over the world, looking everywhere for useful plants, studying everywhere the methods by which the plants are best grown, and then sending homewards their seeds, or fruits, or cuttings, as the case may be, and also notes on the way to grow the plants, the kind of soil, the manure to use, the season to plant, and so on. Then, the people at the Central Office, who receive the plants, must first settle where and how they should grow them; then they must grow them, and sometimes there are great difficulties in the way of this. Then, if they succeed, they must supply plants or seeds to the farmers, and encourage them to make experiments. After all this work is done, much still remains. Often the desperate struggle against disease only begins when the plants are grown on the large scale, and it may be so severe that it requires 
infinite patience before it is certain whether the plant is worth cultivating or not.

The subject is perhaps more systematically worked at in the United States than elsewhere, because there is such a vast territory still to be brought into cultivation, and also because, as we

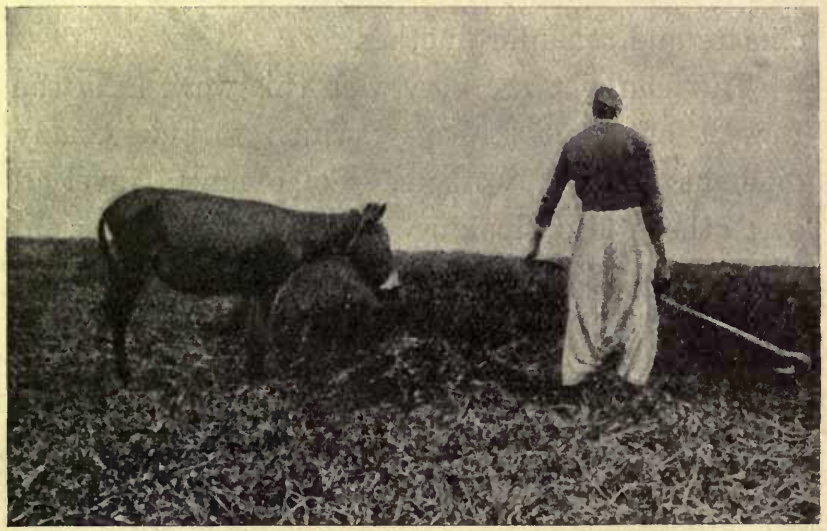

FIG. 14. - Cutting Berseem or Egyptian Clover in Egypt. This is one of the plants which have helped to make Egypt prosperous.

have seen, relatively so few cultivated plants existed in the country when the Europeans first went there. But one must not suppose that America is the only country where this happens. All countries which are only partially developed must in the same way toil to find suitable plants. When we read of the rapid rise in the prosperity of Egypt, of the Argentine, and so on, we must not forget that at 
the back of this rapid rise there has been patient, toilsome work, work of which numbers of people know nothing, because the Tajimas of to-day do not always even get a monument erected to them in the churchyard. It is this silent continuous work which makes the prosperity of new countries possible.

One or two examples will show us the kind of work that has to be done. For instance, it is very obvious, is it not, that if we were trying to introduce new plants into a country, the first point we should have to consider would be the climate? It would be no use trying to grow plants from the south of Spain or Italy in Canada or Alaska. But how are we to find out exactly what is the climate of a place? The people of a particular region can, of course, always give a general idea. We all know, for instance, that in England it is never very cold in winter and never very hot in summer. But how many of us could say exactly how hot it is in summer, exactly how much rain there is in the year, and when the first frost comes in autumn?

Even people who have lived the whole of a long life in a country have often quite vague ideas in regard to its climate, and yet when it comes to be a matter of introducing new plants, the amount of summer heat, the amount of rain in the year, the time when winter begins, are all of the greatest 
consequence. In this country, and in all civilised countries, there are therefore people whose business it is to record day by day, month by month, and year by year, the temperature, the amount of rain, the dampness of the air, and so on. Each little observation is in itself of very little consequence, but when the observations have been carried on for many years, then we really know what is the climate of the country.

In an old country like our own an exact knowledge of the climate is in some ways of less importance than in a new one, for a condition of balance between the cultivated plants and the climate has long since been established. But it is quite different in a new country. Suppose we take some district in our country where the weather has been observed for fifty years. It is found by comparing the results of all those years that we can draw up lists of probabilities about the weather. We cannot make any definite statement about any one year, but we can say, for instance, in regard to autumn frost-the first frost is not likely to be before such a date or after such a date. The farmer knows then that if he does not get delicate crops in before these dates he may lose them.

Suppose now we take a new country where the climate is not well known. A farmer plants a delicate crop; he finds it does well. He plants 
more and more of the same plants, and for a few years all goes well. Then one year an early frost comes and his crops blacken in the field before they are ripe, with the result that the farmer is half ruined. If he learns in this way that he will be likely to lose his harvest perhaps every five or six years, it is clear that the particular plant is not worth growing. But if the weather had been observed for ten years or so, it would have been possible to tell him that it was an unsuitable crop, and so prevent him ruining himself. Therefore, before the Bureau of Plant Industry in the United States recommends farmers to grow particular erops, it must not only find out what climate the plant requires; it must also collect facts about the climates of different regions, so that it is able to say-this region is suitable, that region is not.

All this means a great deal of hard work and a great deal of expense, but the people of America have learnt by experience that it is better that the Bureau of Plant Industry should do this work, rather than that individual farmers should have to do it for themselves, and perhaps lose everything in the process. Even with all the experiments it is impossible to avoid serious loss sometimes. For instance, when Alaska began to be opened up, the people tried to grow the same plants that flourished in the Great Plains, where 
the winters are nearly as cold as in Alaska. They forgot that the summers were much shorter and much colder, and they had to stand by and see

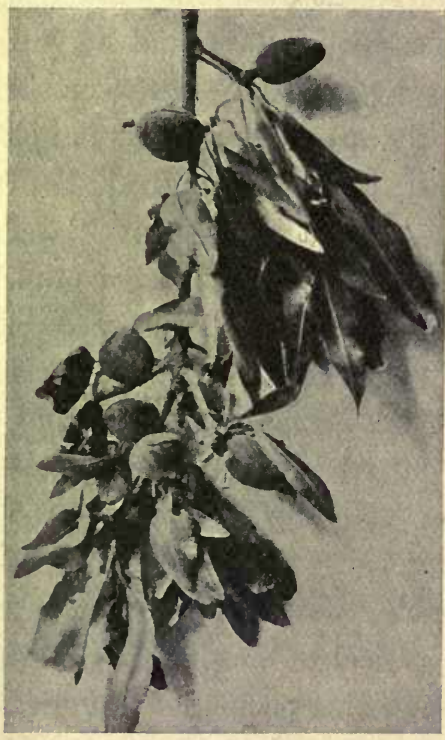

Fia. 15.-Branch of Spanish Almonds. These Almonds have been introduced into parts of the United States. their crops blacken with the frost before they were half ripe. But the Government botanists remembered that the summers were as short and as cold in parts of Northern Europe, and they brought over plants from Norway, Sweden, and Finland, which were too well accustomed to cold to refuse to ripen in Alaska.

Again, in some parts of California, great almond orchards were started, but it was found that the rainfall was too light for the nuts to swell and ripen properly. Then it was remembered that in parts of the Mediterranean where the rainfall is too light for the almond, the pistachio nut does well; so pistachio trees were brought over from the 
Levant, and seem likely to flourish. There are a great number of similar cases which help to show both how much work there is to be done, and what useful work is being done. In the next chapter we shall describe some special cases.

\section{CHAPTER VI}

THE SPREADING OF FOOD-PLANTS (Continued)

WE saw in the last chapter that, in the history both of the Chinese and of the Japanese, we have examples of people who deliberately set out to seek useful plants which might be introduced into their own country, and thus became public benefactors. We saw also how nowadays, in other nations, the same thing is done, but on a much bigger and more elaborate scale. There are many interesting stories of this kind that might be told. How tea and rubber got to Ceylon, for instance, how quinine was carried from South America to India, how cocoa was carried to Africa, and so on, but we shall take here a few examples from the United States.

Let us begin with a simple case. We know from the story-books that American children are fond of cake, indigestible cake, plum-cake, full of 
all the things that the doctor disapproves of. Among these indigestible things an important item is candied peel, and especially citron peel, the thick succulent peel that some of us have helped to cut up at Christmas time. Now this peel had, until lately, to be taken to America right across the ocean, most of it from Corsica and Italy. But California is in some respects like Italy, and it occurred to some one there that, if he could grow citrons on his farm, it would be easy to get sugar to candy the peel, and he might supply his own country with peel, and so make it easier for every child in the States to get his poundeake at Christmas. It was, at least, worth while to try, for the children of America - perhaps helped a little by their elderseat more than two million pounds weight of citron peel in the year. So this progressive farmer wrote to the Secretary of Agriculture and said he would like a few citron grafts for his orchard.

Now the Secretary of Agriculture had no citron grafts in stock, but he was not a man to let that influence him in any way. He simply told one of the travelling experts that he had better go over to Corsica and bring back some nice citron buds which could be grafted on other trees of the orange family in California. The expert was accustomed to have such instructions given to him, so he packed his box and departed for Corsica. That 
was easy; it was the next step that was not quite so simple. The explorer was afraid that the prudent Corsicans might not care to give him grafts of their good citron stocks, for the same reason that the Government in South Africa will not let either ostriches or ostrich eggs go out of their country if they can help it. The Corsicans might be disposed to say: "We can send you all the citron peel you want for your Christmas cakes, and we are quite willing to go on doing it; we don't at all want you to grow your own peel."

The explorer thought therefore that perhaps he would be wiser to go right up into the interior of the country where the people might be less cautious. They were less wise, no doubt, but they did not care for strangers, and the policeman promptly put the poor botanist into jail on the ground that he was a suspicious foreigner with no passport and no apparent business. The prison was very dirty, and the explorer was both very anxious to get out and very reluctant to explain fully what his real business was. He had no official papers either, for he had foolishly left them behind at the port. However, he had in his pocket an American cheque, and he declared to the guard that this was the paper required which proved that he was an American citizen, and had better not be meddled with.

Eventually the policeman gave in, and the botanist 
left hurriedly, having managed to seize a few scions, that is, little branches which could be grafted on other trees. He managed to get these, or some of them, safely across the ocean, and then they were used to graft a small orchard in California. Ten years afterwards (a citron orchard cannot be made in a day!) he went out to California and had the satisfaction of seeing that the citrons were doing well. In a few years more the orchard began to pay, and now its owner is putting his own candied peel on the market, and says that it is much more digestible than any other kind. If that is true, he has not only made it easier for every one to have plum-cake, but also he has made it less dangerous!

Perhaps that seems rather a frivolous story, for, after all, people could do without citron peel in their cakes. Let us take a more serious one. In another chapter we spoke of alfalfa and of its great use in all the dry lands in the United States; how it not only grows on newly reclaimed land but actually prepares the land for other crops which come after; how it resists drought and how it tolerates alkali. Well, it is so important that some of the members of the Bureau of Plant Industry are always busy with experiments on it, and with the search for new kinds, suitable for different parts of the States. So important is the 
plant that it is necessary to have varieties which can be grown in all kinds of climates.

One very important point about alfalfa as compared, for instance, with some clovers is that it is perennial, that is, comes up year after year. The result is that where the winter is short and mild it can be made to furnish a great many cuttings of hay. It grows to a certain height and then is cut down, but if the fine weather continues, and water is supplied, it grows again and gives another crop, and so on, until it seems like a veritable gold-mine to the farmer.

But most strains of alfalfa are tender plants; they require a moderately warm climate, and are readily killed by winter frosts. This is a great loss to the farmer, who in many regions is dependent on the alfalfa crop to feed his beasts. Therefore the Bureau of Plant Industry has made a series of very elaborate experiments on different kinds of alfalfa, so as to try to find kinds suitable to all the different climates of the dry regions of the United States. It is not possible here to describe anything like all these experiments; let us take an example to show the kind of work that has to be done, and the usefulness of the work.

During the experiments, alfalfas were collected from all the different parts of the world where they 
could be got-from South America, from Arabia, from Turkestan, and so on. Among these, one from Peru distinguished itself by its rapid growth and the way it went on growing after it was cut, and also the way it grew even in winter. It was thought then that it would be a good plant to grow, but unfortunately it proved to be very sensitive to frost. In a great number of the stations where it was tried it was promptly killed down by the frost, while some other varieties were not affected. A note was therefore made to the effect that this variety is sensitive to cold, and is only suitable for places like Arizona, where there is not severe winter frost. But-and this is the curious point - while it is very sensitive to severe cold, it is not affected at all by moderate cold, and goes on growing quite contentedly through the cold weather of Arizona. The other varieties, which are not killed by severe frost, yet stop growing so soon as the weather becomes cold.

Just consider what this means. One of the hardy alfalfas will live through a severe winter, even in the northern parts of the United States, but it promptly stops growing as soon as it becomes even a little cold. Peruvian alfalfa is killed by severe frost, but it grows on steadily through moderate cold, when the other kinds are simply waiting for the warm weather to come again. 
The result is that when the hardy kinds are grown in Arizona, practically they do not grow at all during the winter, mild though it is, while the Peruvian kind keeps on growing steadily, so that by the end of February, when it is still winter, it has grown to a height of two feet, and is ready

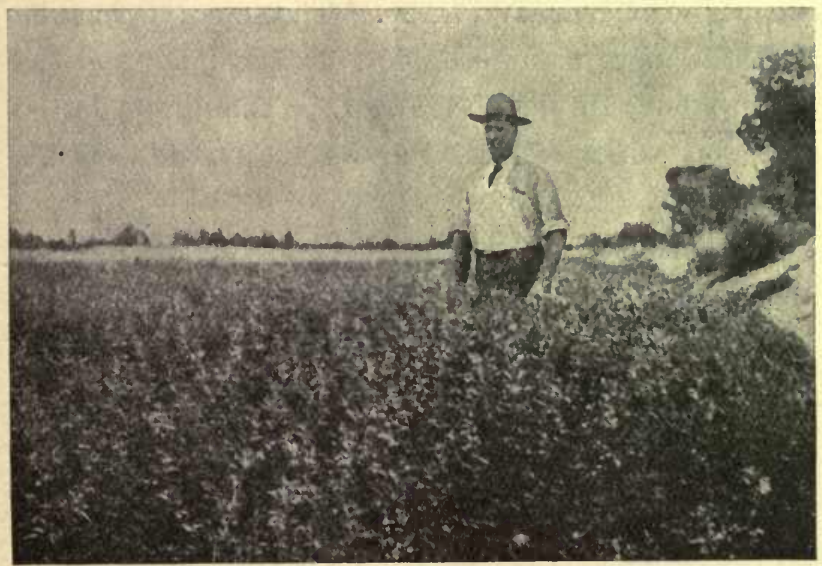

FIG. 16. - A Field of Peruvian Alfalfa.

to be cut as hay. Thus while the other alfalfas in Arizona have only a short growing period, the Peruvian kind goes on growing continuously, and is therefore always taller, and always gives better crops than the others. For parts of Arizona it is the best kind, but as farther north it is almost always killed in the winter, it is quite unsuitable. 
This is an example of the kind of work which is done, and can be done profitably, by experts such as those of the Bureau of Plant Industry; and it shows how much they can help the farmers. For remember that the more alfalfa each particular field can be made to grow, the more beasts the farmer can rear and keep. The more beasts he has, the more manure he gets for his land, and the more labour to plough his land. The alfalfa is the base on which stands the whole pyramid of his prosperity.

Let us take one other example of the work of the Bureau, the very interesting one of the prickly pear, which is really a kind of cactus. Most people have an idea that cactuses grow in all deserts, but in point of fact they belong to the American deserts. When the Spaniards first went to Mexico they found there the different kinds of prickly pears, or opuntias, to give them their scientific name. As the pictures on pages 73 and 74 show, prickly pears are made up of a great number of flat green plates shaped like racquets and covered with prickly spines. Like other cactuses, they flower freely, but they differ from most in producing nice sugary fruits, a little like green figs in appearance. In ancient Mexico these fruits were eaten, and the plants were cultivated for the sake of the fruits. The plants have another interest, for on 
one variety the little insects live which make the dye called cochineal.

Now prickly pears are very easy to grow. Tear off one of the racquet-shaped branches and stick it into the ground, and if the soil and climate are suitable, it will grow and branch very soon. Further, as these branches keep the water they contain for some time, they wither very slowly, and after being carried over long distances will still grow when stuck into the ground. Another simple way of growing them is to sow the seeds out of the "pears" or fruits. Because they were so easily transported, and because the fruit was nice to eat, the first Spaniards brought the plants back to Spain with them.

In Spain and North Africa the prickly pear found just the hot dry climate that suited it, and it flourished apace, escaped from cultivation, and ran wild everywhere. Nobody in Europe had ever seen a plant like it, and everybody was greatly interested in it. The botanists in the sixteenth century all speak of it, and so it is easy to follow its progress as it was carried to all the suitable parts of the Mediterranean region. When the Moors were turned out of Spain, they apparently took the plant with them over to Barbary, where they called it the "Christian fig," to distinguish it from the other fig, which had been cultivated very much longer, and was common to Christians and Mohammedans. 
The plant has a great many uses, especially in hot dry regions. First we have the fruit. It is sweet but very full of seeds, and therefore people like the Americans, accustomed to all sorts of splendid fruits, are not so fond of it as simpler people like the Arabs, who, in Tunis and Morocco, eat enormous quantities of it. But it is a very variable plant; some kinds have very many fewer seeds than others, and there seems no doubt that with careful cultivation kinds entirely without seeds could be grown. Its first use, then, is as a fruit.

Another very important use is that it makes a splendid hedge plant. Some kinds are so prickly that no animal will try to push its way through, and, therefore, it can be used to enclose crops that must be protected from grazing animals. It is much cheaper to grow prickly pear in this way than to make a fence of wire and wood; and the ordinary hedgerow plants of cool damp countries will not grow in the heat and drought of dry countries. This is, therefore, a second great use which it has.

But it has still other uses. In the Mediterranean region the camel, which has always lived in the deserts and therefore is not particular about its food, can often be seen feeding upon it. The very spiny kinds, such as those which are used for 
hedges, are not suitable for animals' food, but forms almost without spines occur in the Mediterranean region. This is a very curious fact which it is worth taking note of. The prickly pear was not originally a native of the Mediterranean region, but in that region enormous areas of land occur which

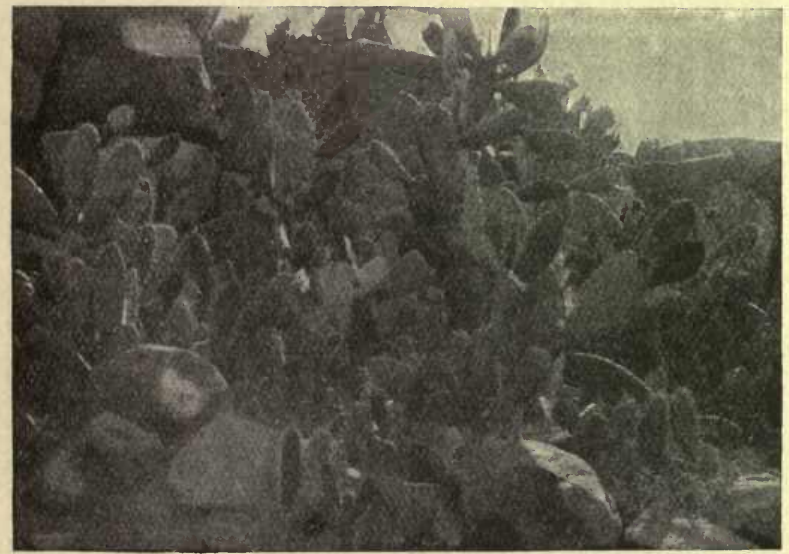

Fig. 17.-Prickly Pear, near Dordrecht, South Africa.

are very well suited to its needs. Once introduced, then, it flourished apace, ran wild, and spread over great areas of the land. This is not at all uncommon with introduced plants and animals. We all know how rabbits have spread over New Zealand and Australia, how some of our weeds, such as thistles, introduced accidentally, have done the same thing. In short, it is quite common to 
find that a plant or an animal which does not grow naturally in a country, multiplies so fast when brought there by man, that it displaces native plants and animals.

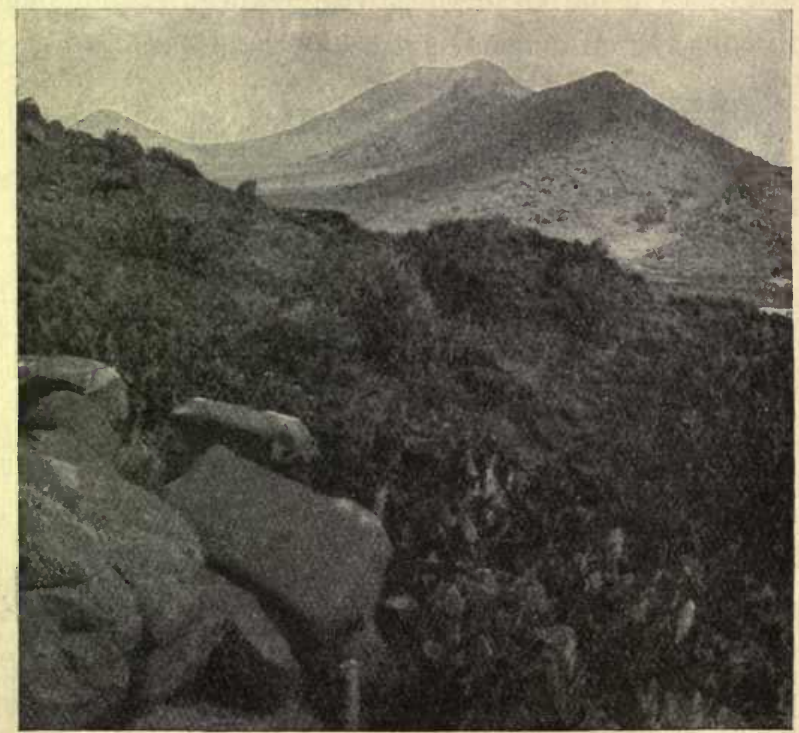

Frg. 18. - Prickly Pear, Dordrecht, South Africa, showing how the plant has run wild.

When this occurs something else frequently happens also. We sometimes find that the introduced plant or animal, in the course of its rapid multiplication, shows all sorts of differences from the original plants and animals. As we say, it runs into many varieties. The original prickly pears 
which were taken over to Europe seem to have been practically all alike, but as soon as they began to spread, all sorts of differences appeared. Some plants were as spiny as or even spinier than the original, but some had hardly any spines at all. Now, even the camel, which is not particular, will not swallow mouthfuls of spines, or at least if he does there are apt to be unpleasant consequences, but both the camel and other grazing animals will eat "prickly" pear which is not very "prickly." In Tunis, in Southern Spain, and elsewhere this was noticed, and as in these places fodder is hard to get for the animals, the forms with the fewest spines were earefully picked out and grown in fields for the farm beasts.

In those parts of the United States where fodder is equally hard to get, the farmers try to use the prickly pear by first singeing off the spines with a torch, and then giving the green joints to their cattle. It would, of course, be much better to grow only the spineless kinds, and the Bureau of Plant Industry is now actually bringing back from the Mediterranean the spineless varieties of the prickly pear to try to grow them in the dry parts of America. This is a very curious factthe re-introduction of a native plant. The experts are searching all over the world, wherever the plant has been introduced, for useful varieties 
which do not grow in the original home of the plant, and are bringing these back to the States, hoping that they may be found useful there.

\section{CHAPTER VII}

OVERCOMING DIFFICULTIES-THE DATE AND THE FIG

So far we have only looked at very simple cases of plant introduction, where the sole difficulty was to obtain suitable plants to introduce. As a contrast let us take the two cases of the date and the Smyrna fig, which have been introduced into North America, but only after most persevering struggles with difficulties, especially in the case of the fig.

Before we can understand what these difficulties have been, we must look for a little at the life of these two plants in the countries in which they were grown originally. Here is a little quotation from Herodotus which not only helps us to understand the difficulties, but also gives a very interesting picture of life long ago. We must remember that this description was written more than two thousand years ago, for Herodotus lived in the fifth century before Christ. 
"The land of Assyria," says Herodotus, "is but little watered by rain, and that little nourishes the root of the corn; however, the corn grows up, and the grain comes to maturity, by being irrigated from the river, not, as in Egypt, by the river overflowing the fields, but it is irrigated by the hand and by engines. For the Babylonian territory, like Egypt, is intersected by canals; and the largest of these is navigable, stretching in the direction of the winter sunrise, and it extends from the Euphrates to another river, the River Tigris, on which the city of Nineveh stood.

"This is, of all lands with which we are acquainted, by far the best for the growth of corn; but it does not carry any show of producing trees of any kind, neither the fig nor the vine nor the olive, yet it is so fruitful in the produce of corn that it yields continually two-hundredfold, and when it produces its best it yields even three-hundredfold. The blades of wheat and barley grow there to full four fingers in breadth, and though I well know to what a height millet and sesame grow, I shall not mention it, for I am well assured that, to those who have never been in the Babylonian country, what has been said concerning its productions will appear to many incredible.

"They use no other oil than such as is drawn from sesame. They have palm trees growing all 
over the plain; most of these bear fruit from which they make bread, wine, and honey. These they cultivate as fig trees, both in other respects, and they also tie the fruit of that which the Grecians call the male palm, about those trees that bear dates, in order that the fly entering the date may ripen it, lest otherwise the fruit fall before maturity; for the males have flies in the fruit, just like wild fig-trees."

Now Herodotus was certainly wrong in regard to the flies in the date fruits, but, as we shall see, he was right in seeing some resemblance in the method of growth between the fig and the date, for both present difficulties that most other trees do not. We should notice also that for Herodotus the supremely important cultivated plants were wheat and other grains, and such fruit trees as the vine, the fig, and the olive.

These were the original food-plants of the countries round the Mediterranean, and it was they which fed the splendid civilisations of Greece and Rome, from which we inherit ours. We should notice also that he saw how useful the date-palm was to those who could not grow vines and figs. His mention of the word bread shows us that he understood that if wheat was not forthcoming the date might alone give almost all that man requires. This of course it does for the Arabs of the desert 
regions, who grow it to perfection, and down to the present time, have obtained from it "bread, wine, and honey."

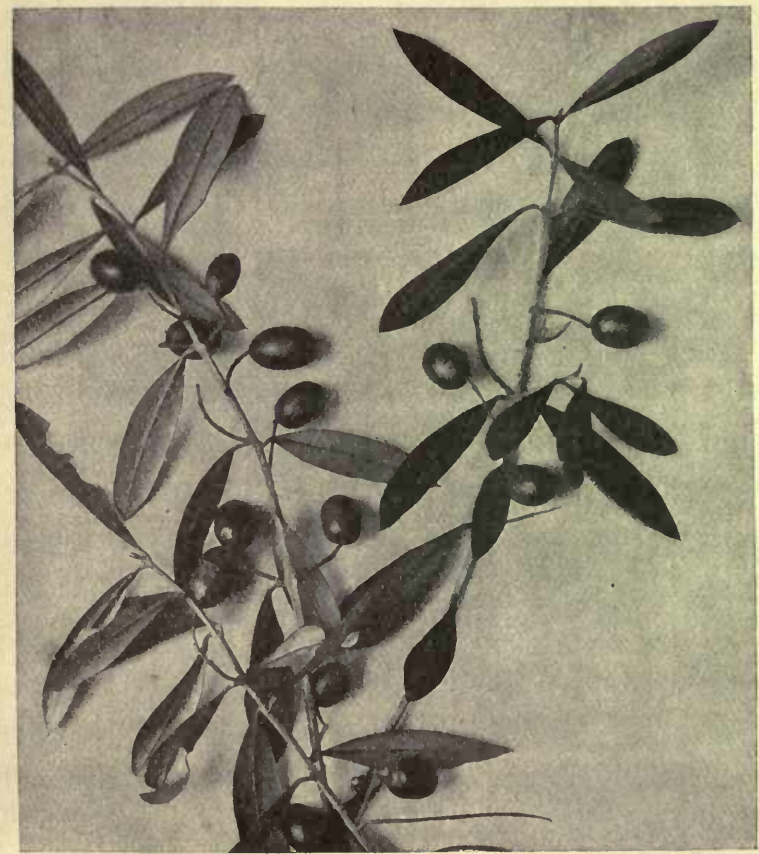

FIG. 19. - Branches of Olive Tree with Olives.

There is a very interesting story about Mohammed (who lived from 571 to 632 A.D.) and the dates which may further help us to understand something about the difficulties of date-growing. We noticed that Herodotus expressly says that not 
all the palms produce fruit. Generally the Arabs only grow the fruit-bearing trees in their gardens and plantations, but in the flowering season they gather the branches of the tree which bears no fruit, as Herodotus explains, and tie them to the fruit-bearing tree. These branches are full of the dust which botanists call pollen, and not till this dust falls upon the flowers will they set to form fruit.

There are thus two kinds of date-palm trees, the pollen-bearing and the fruit-bearing. In the wild state the wind carries the dust from one kind of tree to the other, but as the Arab does not want to cultivate the pollen-bearing trees and get nothing for his pains, he grows the fruit-bearing only, and as they ripen gathers the dust spikes of the other tree to fertilise his dates. We can explain that very simply now, because about a thousand years after Mohammed a German botanist called Camerarius first showed clearly that seeds never set in flowers unless the fertilising dust falls upon the pistil, which is a part of the seed-bearing organ.

After Camerarius many other botanists worked year after year, and they worked so well that now every student of botany is shown things the ancients never dreamt of, shown how the pollen grains put out a little tube, which creeps down into the seed-box and turns the little empty "ovules" 
into plump seeds, capable of growing into new plants. It is easy for us, then, to explain why the Arabs and the Assyrians tied the pollen-bearing flowers to the fruit-bearing flowers, but though they knew they must do it, they could give no reason for it.

Now Mohammed was in some ways a thinker; not a very deep thinker perhaps, but still he did not like simply to take things for granted. He asked himself : "Why do my people tie the branches of the wild palms to the cultivated palms in their gardens?" Nobody could give him any answer, and he decided that it was superstition only. Though we do not know for certain, it is at least probable that the tying was accompanied by ceremonies, and that it was the ceremonies especially that Mohammed objected to as degrading and superstitious.

We saw in another chapter that it often happens that operations connected with agriculture are bound up with apparently foolish ceremonies. The English farmer, whose labourers dress up a "corn-maiden," does not now believe that the cornmaiden makes any difference to his harvest next year, but his forefathers believed this firmly. It is quite-likely, then, that Mohammed thought that the tying of the branches of wild dates on cultivated date-palms was only an excuse for foolish ceremonies ; in any case he issued a decree that no one 


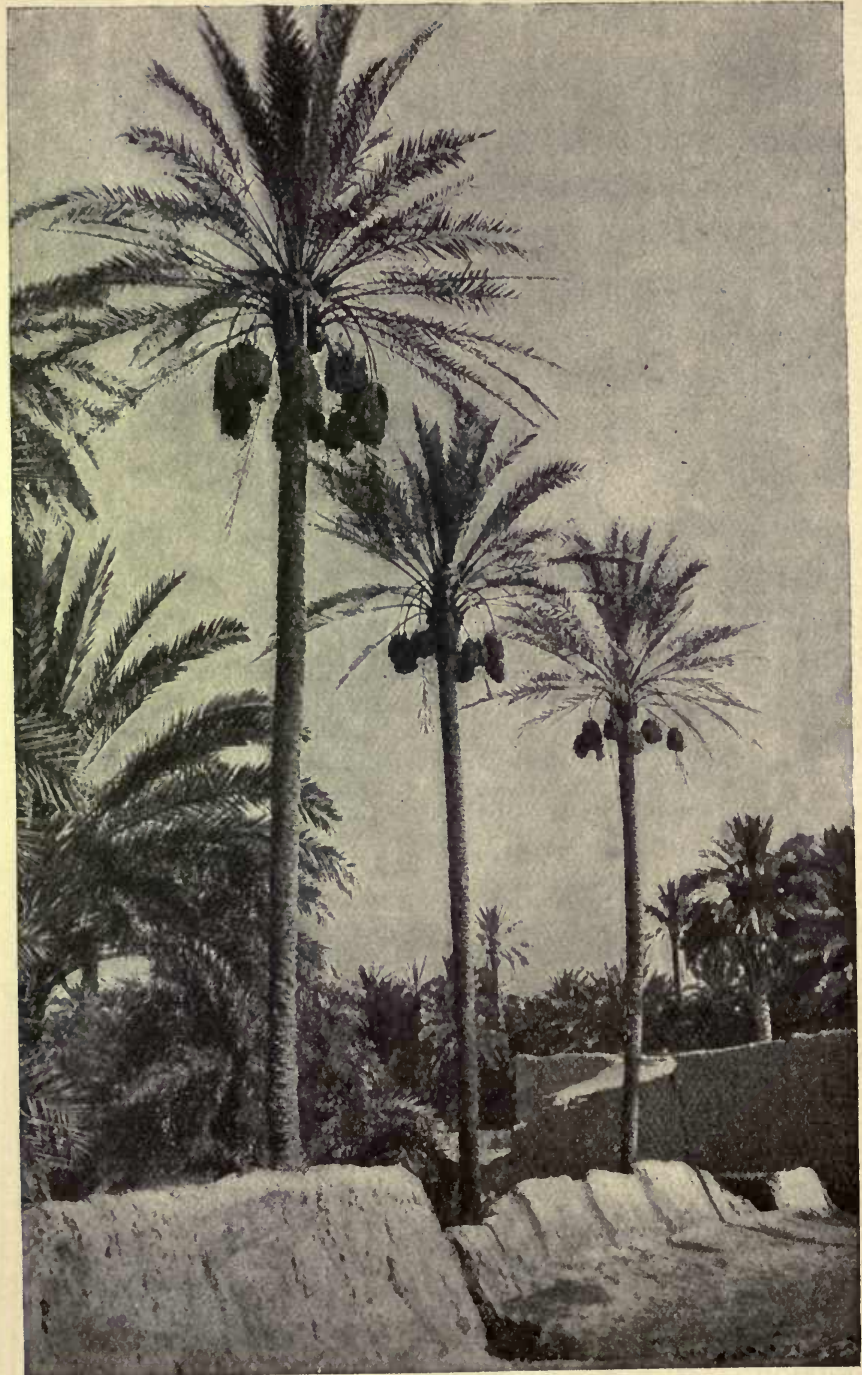

FIG. 20. -Date-Palms, loaded with Ripe Fruit, Biskra, Algeria. 
of his followers was to practise this rite any more. Perhaps, considering that his followers, like the other Arabs, lived chiefly on dates, it would have been wiser to have made the experiment on one date-palm, to be sure that it was only a foolish ceremony, but Mohammed was an enthusiast, and enthusiasts do not always stop to think.

His fiat went forth then-no branch of the wild date is to be brought into the garden of a believer. They must stand idly by while the unbelievers carry out the operation as usual. $\mathrm{He}$ was obeyed; he knew how to make himself obeyed, but in all the gardens of his followers no date swelled and set, no fruit hung from the tree in harvest-time. All the months when the unbelievers' dates were growing amber-coloured and translucent on the trees, the Mohammedans must needs stand aside and watch the unfertilised flower clusters wither on their own trees, must see in their store-chambers the pile of last year's dried dates slowly diminish, knowing that no luscious, sugary fruits would come to take the place of the old. We must admit that it was a severe trial of faith !

But Mohammed, who did not lack resourcefulness, just at the time when starvation was beginning to stare his followers in the face, issued a new edict, that Allah permitted the true believers to pillage the caravans of the outside world. It was this 
edict, says Professor Margoliouth, which started the Mohammedans on the period of conquest. which transformed the Old World. If Camerarius had lived a thousand years sooner, the history of the world would perhaps have been different!

The case of the date-palm is, however, simple compared with the fig, for we know now that some datepalms produce only pollen-bearing flowers, and some only fruit-bearing flowers, and either by the wind or by man's agency the dust must be carried from one kind of tree to the other. The case of the fig is more complicated.

Let us look first at Pliny's account of what was actually done in his day - that is, at about the beginning of our era. Pliny was a Roman naturalist and author who lived in the years 23-79 A.D. He did not confine himself entirely to facts, but offered a few explanations of his own. Some persons may be disposed to say that they do not understand his explanations, but this cannot be helped, unfortunately, and the only consolation is that there is every reason to believe that Caius Plinius Secundus, otherwise called Pliny the Elder, did not understand them himself-he only hoped that some one else might. Here is what he said:-

"The wild fig, known by the name of caprificus, never reproduces itself, though it is able to impart to the other the principle of which it is thus 
destitute, for we occasionally find Nature making a transfer of what are primary causes, and being generated from decay. To effect this purpose the wild fig tree produces a kind of gnat. These insects, deprived of all sustenance from their parent tree at the moment that it is hastening to rottenness and decay, wing their flight to others of kindred though cultivated kınd. There, feeding with avidity upon the fig, they penetrate it in numerous places, and, by thus making their way in to the inside, open the pores of the fruit.

"The moment they effect their entrance, the heat of the sun finds admission too, and through the.inlets thus made the fecundating air is introduced. . . Hence it is that in the plantation of figs a wild fig is usually allowed to grow, being placed to the windward of the other trees in order that the breezes may bear it upon them. Improving upon this discovery, branches of the wild fig are sometimes brought from a distance, and bundles tied together are placed upon the cultivated tree."

From this account we can at least make out that in Pliny's day, as in many places at the present time, it was customary either to plant the wild fig (caprifig) plant in the plantations, or to bring branches of the caprifigs into the plantations at the flowering season. Further, from his account we see that it was known in his day, as well as in 
that of Herodotus, that the caprifigs had inside them a little insect, which we know now to be a tiny wasp, which helps in the process of fertilisation.

The curious point, however, which makes this case more difficult to understand than that of the date, is that Pliny knew that caprification (the bringing of the caprifig branches) was.not always necessary; some figs would ripen without this, while dates will never ripen unless the pollen is brought to them. At the present time some figgrowers still practise caprification, while others say that it is not necessary. Leaving this for a moment, however, let us go back to Pliny's explanation of what happens in the wild fig.

"It is beyond all doubt," he says, "that in caprification the green fruit gives birth to a kind of gnat, for when they have taken their flight there are no seeds to be found within the fruit: from this it would appear that the seeds are transformed into these gnats. Indeed, these insects are so eager to take their flight that they mostly leave behind them either a leg or a part of a wing on their departure."

He had a great appetite for marvels had Pliny, and to him, if flies came out of a fruit, it was clear that it was the seeds which had been turned into flies - the idea that other flies had laid their eggs in the fruit never occurred to him. There would 
be nothing marvellous in that, and he did not consider that his book would be sufficiently interesting unless it was full of marvellous stories. There is almost no end to the wonders of the wild fig in his eyes, for " a branch of this tree attached to the neck of a bull, however furious, exercises such a marvellous effect upon him as to restrain his ferocity and render him quite immovable."

Probably Pliny never had sufficient curiosity to try the experiment himself; perhaps one of my readers would like to try.

But we must go back to the figs. Perhaps we do not know the whole story even yet, though there have been many people who have worked hard to find out what it all means. We know, however, a good deal more than Pliny did. We know first that though the caprifig never produces edible figs, yet some kinds have pollen-bearing flowers as well as seed-bearing ones, and, as Herodotus and Pliny already knew, these wild figs have tiny wasps inside. The cultivated fig, which we eat, never or rarely has pollen-bearing flowers, and, therefore, if they are to set seeds, the tiny wasps from the caprifigs, which are always covered with pollen, must find their way into them.

But there is this great difference between the date and the fig: that if the date be not fertilised it never swells up into the edible date, but figs do swell up 
even if they are not fertilised. For the botanist the fig is not a true fruit like the date, but a cluster of tiny flowers, and it is the tiny flowers which we eat. The figs which are eaten green are not generally caprified. They do not have true seeds inside, but,

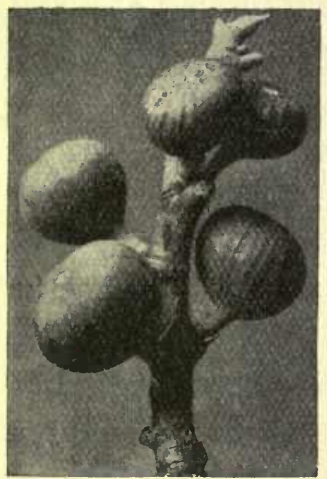

Fig.21.-A Twig of a Smyrna Fig-tree bearing Figs. The smooth swollen Figs to the left have been caprified, the wrinkled righthand Figs have not. as every one knows who has tried, they are quite good to eat. On the other hand, the dried Smyrna figs which we eat at Christmas must be caprified, otherwise they will not ripen and will not dry properly.

To sum up, figs which are not caprified do not contain fertile seeds, but these figs may be quite good to eat, though they do not dry well. The figs which have most flavour when dried are the kind called Smyrna figs, and these must be caprified. Caprification means the carrying of pollen by tiny wasps from the wild figs to the cultivated ones. Next time we eat a dried fig, we should notice that at the top of the fig there is always the remains of the little hole through which the fig-wasp entered in order to fertilise the fig. 
In the next two chapters we shall consider how the Americans have had to toil in order to introduce dates and figs into North America.

\section{CHAPTER VIII}

\section{INTRODUCING DATES INTO NORTH AMERICA}

The Arabs grow dates so well and make so much use of them that the idea of introducing the datepalm into other countries with a suitable climate has naturally occurred to many people. So far as regards the Old World, however, it is remarkable that, ancient as is the cultivation of the date-palm, the area over which it is grown with success has always been limited. Thus, at different times, datepalms have been taken to China, a country of very skilful cultivators, but it has never been grown there on a large scale, and is not grown at all now. It was introduced by the Moors into Spain, but the date-palms of Spain are not to be compared with those of North Africa. Perhaps this is in part due to the fact that the date-palm is very particular as to climate, but it must also in part be due to the fact that it is difficult to grow.

The people round the eastern and southern parts 
of the Mediterranean basin have grown dates for thousands of years, and they have acquired a kind of skill which it seems difficult for other peoples to acquire. We find, therefore, that, despite all their perseverance, knowledge, and cleverness, the people in the warmer parts of North America have taken a very long time to introduce the date successfully. It seems probable that they have succeeded now, but it is only after many attempts.

The first attempt was made by the Spanish missionaries, who introduced many useful plants. They planted in California, during the eighteenth and the early part of the nineteenth century, date stones, brought either directly from Spain, or obtained from palms grown in Mexico from Spanish seed. The seeds so planted grew into fine trees, the descendants of which are still living and form great ornaments to the landscape of Southern California. This first planting had, however, several great drawbacks. In the first place, it was found that trees grown from seed consist in nearly equal numbers of pollen-bearers and fruit-bearers - that is, about half the trees bear no fruit. Secondly, Spanish dates are not very good; we shall see directly that dates grown from seed are not often good. Therefore, though about half of the Spanish trees bore fruit, yet very few indeed of these had fruit which Americans think worth eating. 
The next serious attempt was made from 1848 to 1880 , when the Americans, as distinguished from people of Spanish descent, were beginning to develop the west. They also grew their date plants from seeds, but they got better seeds, brought from the region of the Persian Gulf. Some of the trees so reared bore good fruit, but relatively few of them did so, and again there was a great predominance of pollen-bearing trees. The methods of cultivation also were not well understood; so that though these continued efforts produced some fruitful palms, yet they did not produce nearly enough to supply the demand in America for good dried dates.

After some time it was recognised that the only way to start date-growing on a considerable scale was to get suckers from the good kinds of Arabian dates. Young date-palms, not the old ones, produce suckers round the bottom, after something the same fashion as was described in the case of the banana. The Arabs never sow date seeds. They mark carefully in their gardens the best kinds of dates, and then the suckers from the young plants of these kinds are taken and used to start new plantations. It is, of course, only the fruit-bearing palms that are reproduced in this way, and thus the Arabs avoid getting a great number of useless plants, such as the Spanish Fathers got. That is the first advantage of their method. 
The second one is a little more difficult to understand. Some of us have been shown how fruit trees are grown in this country, and we know that gardeners who want fine apples never think of planting apple pips, even from a very beautiful apple. They take a bud from a good apple tree, and graft it on another young tree, from which all the branches have been cut off. The bud grows on the stock, as it is called, and produces a tree exactly like its parent. If we ask the gardener why he does not just sow the seeds, he will tell us that the seeds do not "come true"; that is, they do not grow into trees producing the same good fruit as the parent. It is much the same with the date. Date seeds do not always grow into plants which produce the same good fruit as the parent trees; but a sucker taken from the base of the parent will produce exactly the same kind of fruit. This the Arabs long ago discoveread.

When it became clear to the Americans that they would never get very good date-palms until they brought over suckers from good kinds, they proceeded to try to do this. But this is not nearly so. easy as growing the plants from the seed. It is only necessary in that case to take a date out of one of the frilled boxes in which we get them, eat the date, plant the stone, keep it as warm as possible in its pot, and by and by the little date 
plant shoots up. To bring over a sucker means a great deal more trouble and expense.

For fourteen years, from 1876 to 1890 , different people went on trying to bring over suckers. They were brought over, a good many of them, but all sorts of accidents befell many. Some were washed out of the ground by the great floods of the Colorado river; some died because the winters in the places where they were planted were too cold; some were neglected by the people to whom they were sent, who thought the plants more trouble than they were worth; some were carefully tended, and then turned out to be nearly useless, because the people from whom they were bought had not chosen to send the best kinds.

But even with all these accidents a few plants survived and did well in certain places. There were enough of these to prove to intelligent people that the date-palm could be made to grow in the western parts of North America, and that all that was wanted was patience, perseverance, and skill. Therefore, in 1899, the Bureau of Plant Industry took up the matter seriously. An expert was despatched to North Africa to choose, buy, and ship offshoots of the best kinds of date-palms, and at the same time to learn all he could about methods of cultivation as practised in the regions where the best dates are grown. It took about three years to 
carry out this commission; but by 1901 the date was fairly established in parts of Western North America, where it seems likely to do well. Thus it took more than a hundred years to establish the date thoroughly in the New World.

Let us look at the work of the American expert

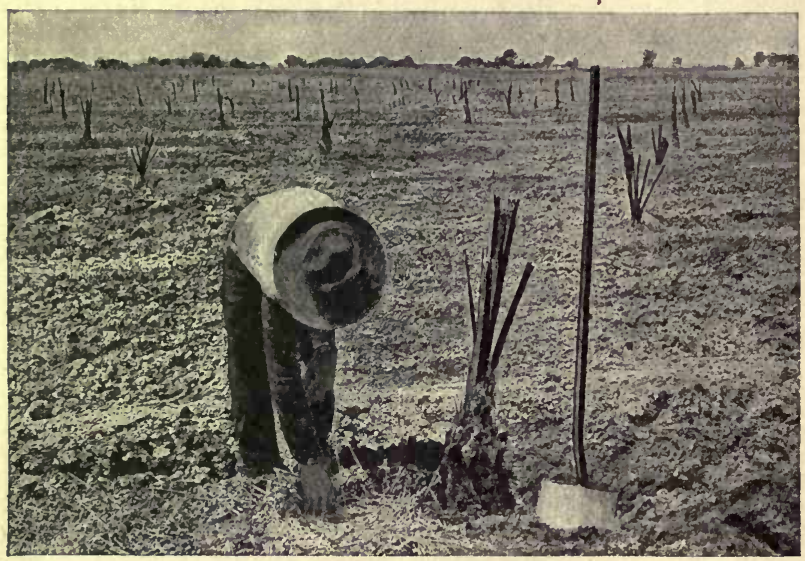

FIG. 22. - Setting out Date Offshoots from North Africa in Arizona.

in a little more detail, and see how he got the offshoots of the good kinds, what he learnt by studying the Arabs' date gardens, and what kind of advice he was able to give the American cultivators.

To get the best offshoots possible, he went to Biskra, the garden of dates, which lies in Algeria on an oasis close to the northern boundary of the Sahara desert, and just south of the Atlas Mountains. 
At the oasis of Biskra there are about 160,000 date-palms, planted, as the Arabs do plant them, without any order or arrangement. Round the central oasis there are some smaller oases, so that altogether there are about 500,000 date-palms near Biskra. Each tree produces, on an average, from 100 to 200 pounds of fruit in the year, so that this is date culture on the large scale. Somebody of a mathematical turn of mind will perhaps tell us how many tons of dates are likely to be grown at Biskra every year?

More than this, though the blazing sun of the desert will not permit other trees or plants to grow without shade, yet it is possible to grow them under the shade of the date-palms, so that these have another use besides fruit-yielding. At Biskra, as Fig. 23 shows, figs are grown under the shade of the dates, and in some places it is usual to grow vegetables beneath the figs. There are thus three tiers of plants:- The great date-palms first, towering high up in the air; then beneath them fig trees or even peach, apricot, and almond trees; and beneath these fruit trees again, garden vegetables, protected from the deadly sun by the trees above.

The expert was, however, not content with his visit to Biskra. He travelled ninety miles farther south into the great desert, down to some special plantations grown by French colonists. Here he 
bought suckers and studied methods, and finally loaded a caravan of camels with the results of his

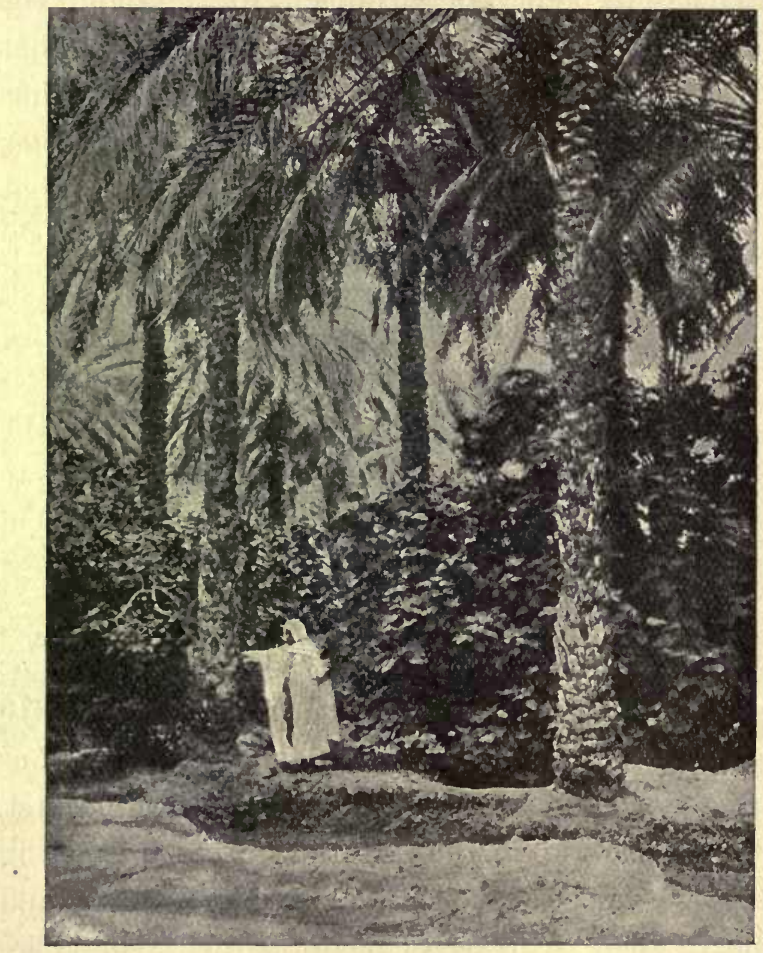

FIG. 23.-Fig-trees growing beneath Date-Palms near Biskra.

search, and set off northwards again. There were many difficulties in the way of getting his precious offshoots across the sea. In the long run, however, all these were overcome, and the suckers were 
carried via New Orleans to Arizona. Here they were set out in an experimental garden, after having been carefully fumigated in case there should be any dangerous insect pests brought over with them.

But the offshoots were not enough ; the question of how they should be grown is just as important, and the expert had therefore to learn all he could, and, with the help of others, to apply the knowledge he gained in this way to the special conditions of North America.

We all know the Arab proverb which says that the date should have its head in the fire and its feet in the water, or, to put the matter more poetically: "The date-palm, the queen of trees, must have her feet in running water, and her head in the burning sky." It was not just at once, however, that the cultivators learnt that this means that the date is not a true desert plant like the Mexican cactuses. It is not an inhabitant of the Sahara, but of the oases of the Sahara. It will not ripen its fruit in a country where there is summer rain or where the air in summer is damp; but it will not grow at all unless the roots have abundant water.

Now this combination of requirements means generally that the date-palm must be artificially irrigated; and it is this which makes it expensive 
to grow. For this reason also the cultivator can only afford to grow the smallest number possible of pollen-bearing trees. Further, in the oases where it grows naturally, and where the air in summer is very dry and very hot, the soil often contains alkali and salt-to these the date-palm is remarkably resistant. If it can get water for its roots, it does not mind if this water is brackish. This is a very important point in connection with its growth in countries like Arizona.

Next to the bringing of the requisite amount of water to the roots of the date, which is often a very laborious process, the most troublesome part of date-growing is fertilising the flowers. At this the Arabs are very skilful, but at best it is a tedious and laborious process.

As we have already seen, each date-palm requires a large amount of water, and, in the country where date-palms grow, water is one of the most precious commodities there are. Therefore, while in the wild state there are as many pollenbearing dates as fruit-bearing, the Arabs only allow one pollen palm for a hundred fruit palms. So much pollen is produced that there is then enough if the pollen is not wasted, as it is in a state of nature. A great difficulty, however, is to be sure that the pollen palms and the fruit palms will flower at the same time. It does not matter much 
if the pollen flowers open before the fruit flowers; for the pollen will keep for a long time, but it is very serious if the fruit flowers are ready to be fertilised before the pollen flowers have opened.

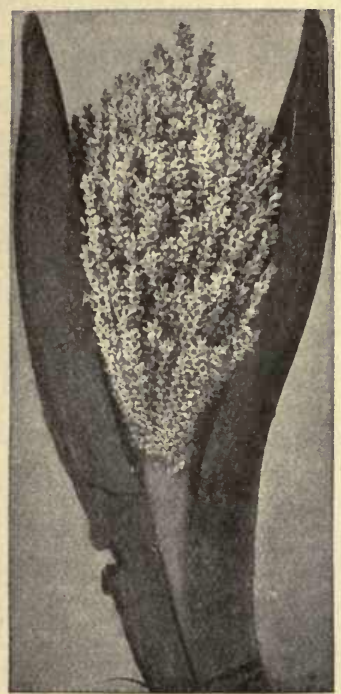

FIG. 24. - Pollen Flowers of Date-Palm.

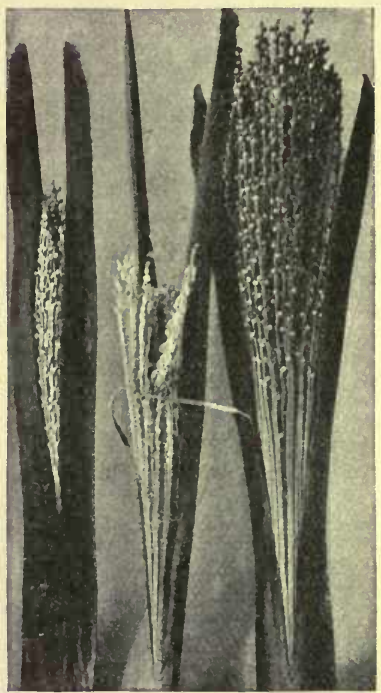

FIG. 25.-Fertilised Fruit Flowers of Date-Palm.

Owing to their long experience, the Arabs have found means to make sure that the two kinds of palm flowers will open at the same time, but in America this is one of the difficulties which requires much care in overcoming.

The Arab also, knowing how supremely im- 
portant the fertilisation is, always takes care to keep a little store of pollen in case of accident. Pollen will keep in a dry climate for at least two

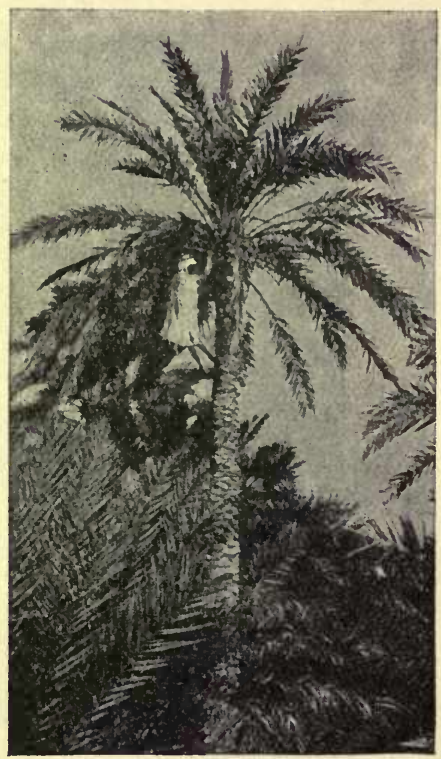

FrG. 26. - Arab climbing Date-Palm to fertilise Flowers, Biskra.

years.

How does the Arab fertilise his dates? Well, the pictures help to show us. He takes a little twig of pollen flowers, then he carefully opens the sheath of the fruit flowers, slips in his bunch of pollen flowers, ties it in position with a piece of palmfibre, and then he knows that there is always sufficient movement in the air to make sure that the dust will be carried to each of the flowers in the fruit-bearing cluster.

When the palm trees are young the task is easy, for the Arab can easily reach the flowers. When they grow older, however, the trees become very tall, and then it is difficult to reach the 
flower clusters. The Arab, who is lithe and supple, climbs up the tall stems with his hands and his bare feet, holding the bunch of pollen flowers and the fibre in his mouth. Quite often he has to ascend the same tree several times, as all the flower clusters do not appear at once, and each one must be fertilised separately. So clever is he, however, and so well have his eyes been trained, that he rarely misses a palm, hardly even a flower cluster. Each tree in full bearing is allowed to produce eight to twelve bunches of fruit; that is, eight to twelve flower clusters must be fertilised. How much tree-climbing then must go on each year before the 500,000 palm trees of Biskra are fertilised each year? Perhaps, when the Americans have grown dates for some time, they will learn how to do the pollinating more simply than the Arabs do it, but that will take some learning.

With all these difficulties is there hope that dates can be grown profitably in North America? Well, it seems that in parts of California and Arizona, especially, dates can be grown more profitably than any other plant, because in these places we have the hot dry summer which is necessary to ripen the fruit; the water can be brought to the roots by irrigation, and this water and the soil often contain so much alkali that not many other plants will grow, whereas the date will 
grow in such soil without difficulty. It is, however, too difficult a tree to grow in a haphazard fashion, and, as we have shown, if success is now within sight, it is only because infinite care and trouble have been spent on learning the why and wherefore of the things that the Arabs do by rule of thumb, for the simple reason that their fathers did them before them.

\section{CHAPTER IX}

THE STORY OF THE SMYRNA FIG

IF the introduction of the date-palm presents some difficulties, that of the fig presents many more. In the first place there is the puzzling uncertainty as. to whether caprification is really necessary or not; and then if it is - and experience has proved that it is necessary with the Smyrna fig-the complications are just beginning. In the case of the datepalm the chief difficulty is to grow the two kinds of palms, and to grow them in the right proportions. In the case of the fig the cultivator must grow (1) the fig proper, (2) the wild fig or capri-plant, (3) he must see that the caprifigs contain the little wasp. As we shall see, all these three presented 
difficulties which took some time and patience in overcoming.

Figs grow freely in Spain and in France, and, therefore, as in so many other cases, it was the Spaniards who first took them to America. In this case the Spaniards were assisted by the French, who took their own figs with them to the Southern States. Throughout the greater part of the Southern and Western States, then, fig trees are common and fruit freely. But the fruit is eaten green, either fresh from the tree, or stewed, or preserved. Sometimes it is tinned, as peaches and apricots are tinned; only rarely are attempts made to dry it. One reason for this is that, in the South, figs ripen at the time of the summer rains, when drying would be difficult.

The result is that, until recently, the fact that figs grew all over the warmer parts of the States did not prevent an enormous import of dried figs from Turkey; this import at one time being thirteen and a half million pounds weight per annum.

These imported figs are of the kind called Smyrna figs, the kind that comes to this country in the familiar little wooden boxes, and which we eat in the winter months. What the Americans wanted to do, then, was to supply this demand for dried figs, and not simply to be content to grow green figs for home use. For some time an attempt 
was made to dry the figs grown in California, where there are not summer showers to spoil the process, as in the Southern States. But the public, accustomed to the well-flavoured Smyrna figs, would not eat the tasteless home-grown varieties.

What was to be done? It seemed clear that the answer was-get some Smyrna fig plants and try them. This was done, first apparently about 1880. It was done by a Californian who had a newspaper connection, and therefore, in the American fashion, he took care that everybody should know that henceforth Smyrna figs were to be grown in America. Thanks to his efforts everybody did know, but unfortunately when the cuttings that he brought over came into bearing, it was found that they refused to ripen their fruit; the fruit dropped off when each was no bigger than a marble. It was clear that something was wrong; but still the first step had been taken-the Smyrna fig plant had been brought over.

Some eight years later another Californian imported fresh Smyrna fig trees. It was thought that perhaps the first importations had not been good kinds, that the fig-growers in Turkey had sent rubbish because they were afraid of losing their market. This time, therefore, a trained gardener, Mr. George C. Roeding of Fresno, California, 
went to Smyrna, and not only bought plants but also studied methods, and as a result brought back caprifig cuttings as well as the edible fig plants.

Two years later, that is in 1890 , both kinds of figs came into bearing, and the Smyrna figs were artificially fertilised by taking some of the pollen out of the caprifigs, and, with the help of a quill, putting it inside the edible figs. As a result four ripe figs were obtained. The year after-we can see what time and patience must go to this kind of work - a glass tube drawn out to a fine point was used, and the pollen blown into the edible figs. This time one hundred and fifty edible figs were produced. Thus, after eleven years of experiments, it was shown that the Smyrna fig would grow in California, and that before it would ripen it must receive pollen from a caprifig. This was the second step - the introduction of the caprifig.

Perhaps some one may say, Why not stop here? If the date-palm is always pollinated by hand, why not the fig? But let us think for a moment. In the case of the date each cluster is fertilised by hand, but each cluster may contain ten or twenty pounds of dates; it is a very different matter blowing pollen into each single fig. with a little glass tube-that could never pay. If the fig-wasp could be introduced into America, it would carry the pollen from the caprifigs to the edible figs, and 


\section{6

thus save all the trouble. The difficulty was to get the wasp. It lives in the caprifigs, but there were, of course, no caprifigs on the cuttings of capriplants brought over from Europe, so how was the wasp to be got? How was the third step to be taken?

Well, a great many ways were tried; it would take too long to tell about them all, but -it became

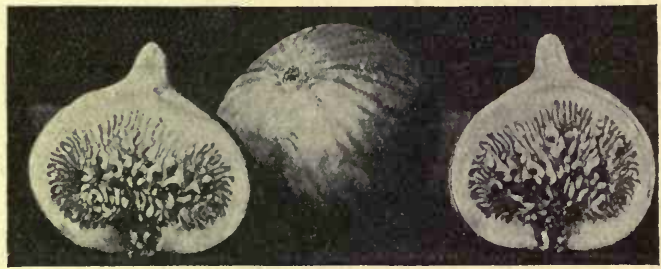

FIG. 27.-Caprificated Figs, whole and cut in half to show Flowers within.

clear that success was impossible until the lifehistory of the wasp was understood thoroughly. Some work had been done already on this question in Europe, some still remained to be done, and further, the peo le who were actually working at the subject in California had not only to learn what had been done in Europe, but had also to find out how the conditions in California differed from those in Europe. We may state very shortly what they learned, and show how it helped them to final success. 
But before going on to this, something else may be said. There are certainly people who will say, What greedy people the Americans must be to take so much trouble over figs and dates! They may be very important to the Arabs in the Desert of Sahara, but what do they matter in America where there are plenty of other fruits? The only answer we can make to that objection is, that if there had not always been on the earth people who were determined not to be beaten, even in trifles, who would go through with a thing because they had begun it, we should all have starved long ago, or have been reduced like the poor Australians to scratching a few miserable roots out of the soil. Civilised man has prospered, has become civilised, just because he has been determined to go through with things, to find out why they were failures, even if he could not always make them a success.

Now let us go back to the fig-wasp. What was found out was this - there are three crops of wild figs : a spring crop, a summer crop, and an autumn crop, which hangs on the trees till spring. The little fig-wasp passes the winter in the autumn caprifigs; but when spring comes it has exhausted the food in these, becomes restless, and, leaving the withering fig, emerges into the air.

By this time the plant is beginning to produce its spring crop of caprifigs. These the wasps enter, 
and, within them, they lay their eggs and die. The eggs hatch into new wasps, which feed upon the caprifig until they have exhausted the food it contains. The new wasps must then in their turn leave the caprifig and go forth to seek a home in which they may lay their eggs. But the spring caprifigs are full of pollen, therefore, when the wasps emerge, they are covered with pollen.

If the fig-grower takes these caprifigs before the wasps have left them, and hangs them over a tree containing edible figs, then the wasps, as they emerge, find their way into the edible figs. They cannot lay their eggs there, for the flower is not arranged to suit them, but they blunder about looking for a suitable place, and in this way they fertilise the little flowers inside the fig. That is, they do what the fig-grower wants them to do.

Finding no convenient place for their eggs in the edible figs, they come out of them again and seek the caprifig trees, where they lay their eggs in the summer caprifigs. In the autumn the wasps leave these for the autumn figs, and in these autumn figs they pass the winter, to begin the whole process over again in the spring. From the wasp's point of view, therefore, the visit to the edible fig is merely a waste of time, because the edible fig has lost, in cultivation, everything that makes it useful to the wasp. But, as the 
resemblance between the two is close, the wasp is easily deceived into paying a visit to the edible fig if the grower is careful to bring the caprifigs close to the edible figs. If he does that, then the wasps do their duty, enter the edible figs, fertilise them, and so make them fat, juicy, and wellflavoured.

But the fig-grower must not stop here. He not only wants to have wasps to fertilise his figs this year, he must be sure that the stock of wasps is kept up so that he may find fresh wasps next year - that is, he must have growing in his orchard capri-trees bearing summer caprifigs ready to receive the wasps when they have fertilised his edible figs. If he has not such trees, then the wasps will die, and there will be none for next year. Thus he has to cultivate fig-wasps (remember they are quite different from the common wasp, and very much smaller), as well as figs and caprifigs. It is rather a complicated matter !

The first difficulty was to get the wasps alive to the States, and this was found very difficult. Not until it was learnt that only the resting-wasps in the autumn caprifigs would stand the journey was this possible, and it took a long time to learn this.

After much hard work and many attempts, in the spring of 1889 boxes of winter caprifigs were 
sent from Algeria to California, and arrived full of resting-wasps. These figs, with the contained wasps, were placed beneath a caprifig tree in California, the tree being carefully covered over so as to prevent the escape of any wasps. Everything was done with the greatest care, but the people in the orchard had very little faith in the result. They thought the wasps were probably dead, and they had tried so long that they seem to have become a little hopeless. However, with or without faith, they took all the trouble they could.

The care was justified, for by the autumn it was found that this caprifig tree was loaded with caprifigs, many of which were full of wasps ready for the winter. In spite of the tent over the tree also, some of the wasps had escaped, some had fertilised edible figs in the orchard, and some had found a winter home on neighbouring caprifig trees. Would the precious wasps live through the winter? That was the question. Everybody was determined that all man could do should be done to help them to do it.

Besides the original caprifig tree, two neighbouring trees were found to have so many wasps in their figs as to be worth protecting. Round these three trees an elaborate canvas house was built, so arranged that in fine weather the trees could be simply covered, but if frost was probable they 
could be carefully protected from the cold. On these three trees about a thousand caprifigs containing resting-wasps were counted. This done, there was nothing more to do except wait for the spring.

When the spring came it was decided that the subject was so important that a special expert from the Department of Agriculture should be sent to watch events. This expert spent almost his whole day in the orchard, watching the insects, and trying to find out all that was happening. About the end of March the wasps finished their winter sleep and began to come forth. By this time the caprifig trees were beginning to produce their spring crop, and into these the emerging wasps passed to lay their eggs. This went on for about five weeks, and the result was the swelling up of a number of the spring figs, showing that the wasps had entered them, laid their eggs there, and the young wasps hatched from the eggs were now feeding upon the interior.

By the early part of June the wasps had exhausted all they could find in the spring figs, and began to emerge in search of new figs in which they in their turn might lay their eggs. This was the critical moment, for it was these emerging wasps which were relied upon to fertilise the edible figs.

All hands were set to work, and the party was 
divided into three groups. One party gathered the caprifigs with their wasps inside, and carried them to headquarters. Here they were strung in

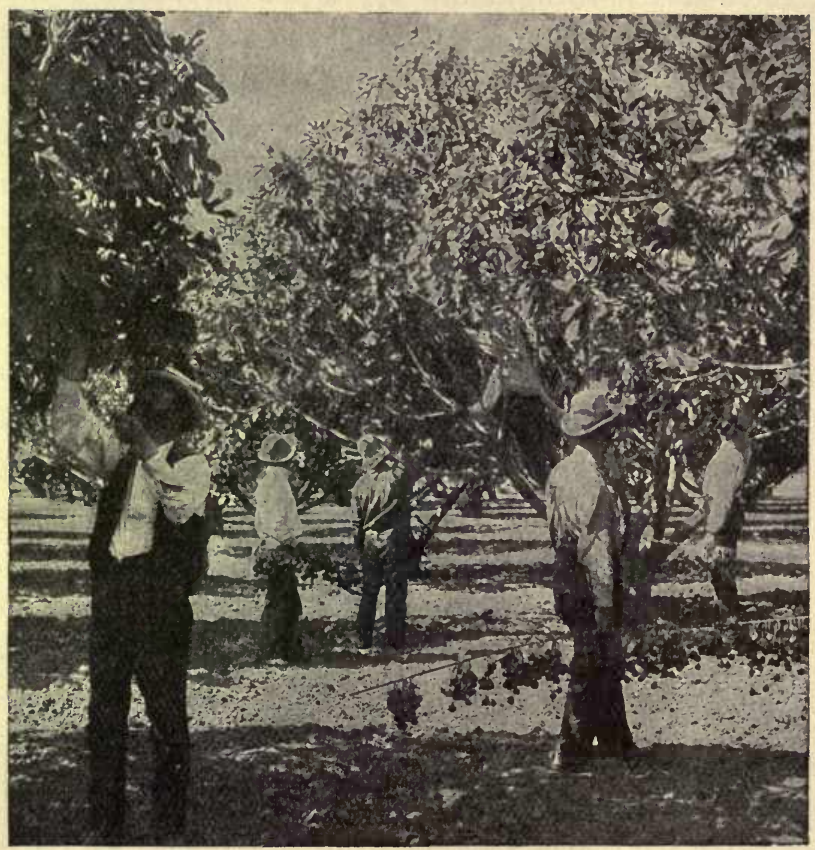

FIG. 28. - Carrying the strung Caprifigs to the Fig Orchard.

bunches on a piece of fibre, the strings being then hung over long poles so that they could be easily carried. The second party carried these strings of caprifigs back to the orchard, and the third had the more delicate work of suspending the strung figs 
over the branches of the trees which bore edible figs.

The work was not all very simple, for, as it was new to every one, there was no experience to act as guide. In the first place the caprifigs had to be sorted carefully, to make sure that they did contain wasps. Then the stringing was not easy. Strong needles were used, but it was found that a milky juice came out of the caprifigs, which soon clogged the needle and soiled the fingers. This juice also affected the fingers of the workmen, so that they became sore and burning, and this was made worse by the constant washing that was necessary.

But, difficult or easy, the work was done; and up and down the orchard of edible figs could be seen the strung caprifigs hanging from the trees. From the caprifigs the wasps soon emerged, and, seeking the edible figs among which they found themselves, they fertilised these, before coming out again to seek for caprifigs.

The experiment proved a huge success. From one cause and another the thousand winter caprifigs with which it began were reduced by the spring to about four hundred and twenty, but from these enough wasps emerged to produce a great many wasp-containing spring figs, and the result of the fertilisation was about twelve to fifteen tons of good 
Smyrna figs, in spite of many losses due to inexperience and various minor difficulties. Here, then, was the third step, the introduction of the fig-wasp, successfully accomplished.

After ripening, the figs were dried in the approved Smyrna fashion, packed in boxes, and proved, according to those who tasted them (but perhaps they were partial!), to be better than the best Smyrna figs. What is certain is that the experiment succeeded, so that after nineteen years of effort the Smyrna fig was grown finally in California.

A little difficulty was experienced in making sure that the wasps would find suitable caprifigs in which to lay their eggs after they had emerged from the edible figs, but this was got over, and all that remained to be done was comparatively simple work - the great steps had been taken.

Three years later, the orchard where these first experiments were carried out produced sixty-five tons of good fruit, and the work is going on steadily now. It is true that the industry of growing and drying the figs is still in its infancy, for the California orchards cannot yet supply anything like the demand that there is in the States for dried figs, but there is every reason to believe that it will go on and prosper. Further, while in Turkey the methods of drying and preparing the figs are not 
always conducted with as much care as they might be, in California great care is being taken as regards these points, and this will, no doubt, make a difference in the taste and value of the figs. The Americans have, at least, reason to be proud of their success so far, and this success has been due to the fact that, instead of being content to wrap ignorance in fine phrases like Pliny, men have spent their lives in toilsome and not directly productive work.

\section{CHAPTER X \\ FOOD AND FOOD-PLANTS}

WE have spoken of the origin of food-plants and of the way in which they have been carried by man over the globe, but we have not as yet said anything of the general characters of food-plants. It is, however, necessary to do this before we can discuss the way in which man has succeeded in improving his food-plants, in making them better, more fruitful, and better fitted for the different countries to which he has carried them.

To begin with, we should notice that the important cultivated plants fall into three groups :- 
1. Those cultivated for their seeds.

2. Those cultivated for their roots or underground stems; and

3. Those cultivated for their fruits.

There are, of course, also plants like cabbages and lettuces which are cultivated for their leaves; plants like cloves which are cultivated for their flower buds; those like cinnamon cultivated for their bark; those like sugar-cane cultivated for their sap; and so on. 'Speaking generally, however, it is the seeds, the underground parts, and the fruits which are important to man for food.

Of these by far the most important are the seeds, and this for several reasons. In the first place, seeds contain, bulk for bulk, less water and more food material than other parts of plants. Another reason, which must have weighed much with primitive man when he began to cultivate the ground, is that the plants which produce the greatest bulk of seeds are annuals, that is, they grow faster than other plants, so that the cultivator does not have to wait so long for his crop as if he were growing fruit trees, for instance.

But before saying more about the different kinds of cultivated plants, we must say a few words about food, so that there shall be no confusion in our minds. In order that we may keep in health we must have three different things in our food. The 
chemist gives these three special names, and there are many conveniences in learning these three names, though two of them are never used in daily life.

The first, and in some ways the most important, is proteid. Many people would use instead of this name the everyday word meat; but this is not exact, for though meat consists of proteid yet we have to remember that bread, for instance, and other vegetable foods also contain proteid. No animal can live without proteid, but we know that the cow does not eat meat-she gets her proteid in the grass which she eats. But as, bulk for bulk, there is always less proteid in plants than in animal matter, the cow must eat far more proportionately than the cat, which eats meat. In the same way with man, the people who eat meat do not need to take so much bulk of food as the people who live on vegetable food only.

The second substance which we need in our food is what is called carbohydrate, which is simply a convenient word to include both starch and sugar. We need far more starch or sugar than proteid, and the bulk of our food is, or should be, carbohydrate. Bread, for instance, is largely made of starch.

Finally, we need an amount of fat, which varies with the climate and the season, and can be got either from plants or animals. 
We need proteid because our bodies are made largely of proteid, and there must always be some proteid added to make up for waste and to allow for growth. We need starch and sugar because we are always moving about and working, and it is starch and sugar which give us energy to move. We need fat to keep us warm, and therefore we need less in summer than in winter, and people in warm countries need less than people in cold.

A missionary who lived with his family in the Far North of America, where the cold is terrible, tells us that if you offered his children a candleend with one hand and a lump of sugar with the other, they would always seize the candle first and eat it with delight. In the same way when Nansen crossed Greenland, he tells us what a fearful craving all his party had for fat of any kind. They each got an allowance of butter, which had to last the week, but most of them could not make this allowance last the week; the temptation to eat it in great lumps was so strong that they could not resist it.

Both these little stories show us how important fat is in a cold climate. On the other hand, in a warm climate like Italy the people practically do not eat butter at all, and take very little animal fat. They take what fat they need in the form of olive oil. Northern people could not do this 


\section{$\mathrm{x}$

because olive oil is not very easy to digest, and it would be impossible to take all the fat that is necessary for them in that form.

To sum up then, wherever man lives he must

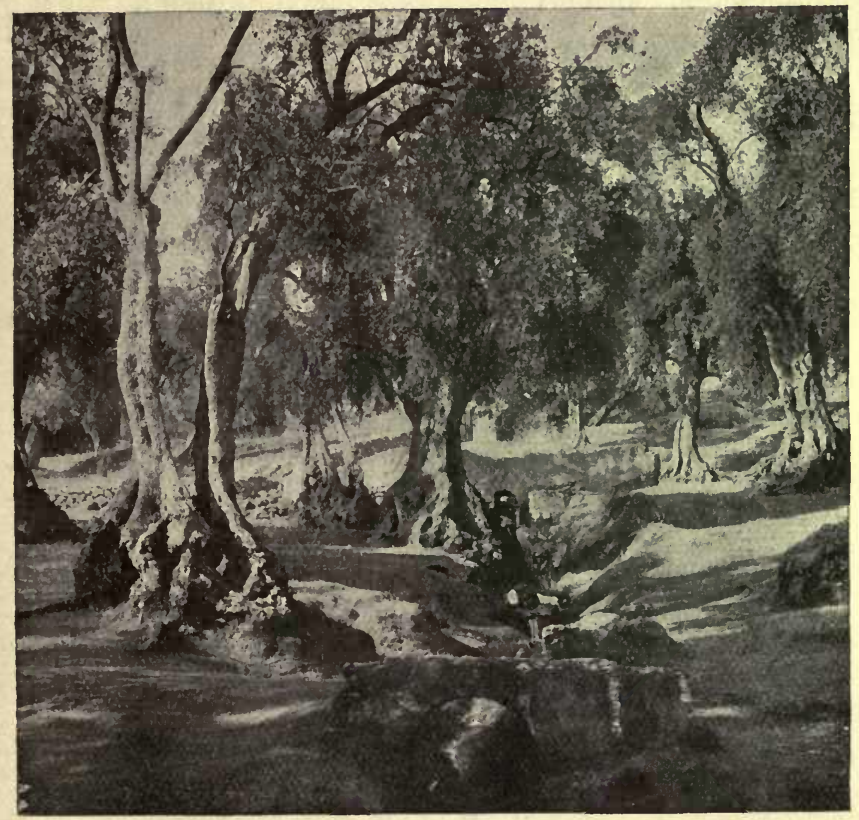

Fig. 29. - An Olive Grove.

have in his food proteid, carbohydrates, that is starch and sugar, and fat. The farther north he lives, however, the more fat he must have, while in warm climates very little fat is necessary. It seems also to be true that in the colder climates he 
requires more proteid than in the warm ones. For both these reasons vegetable food is more important to people in warm climates and animal food to people in cold ones, for they must have much digestible animal fat and much proteid. For instance, the Eskimo in the Far North take practically no vegetable food, while many of the peoples in the tropics take practically' no animal food, and between the two we have all gradations.

Now let us go back to the kinds of plant food. We find that the seeds which man uses as food contain more proteid and more fat than any other parts of plants. The roots which he uses usually contain a certain amount of proteid, but very little fat; their chief contents are starch or sugar. Fruits contain chiefly sugar or more rarely starch; they have very little proteid, and not usually any fat.

The reason of all this is easily seen. Seeds, as we know, contain the young plant. Just as the cow's milk contains everything that the calf wants, so the seed contains everything that the little plant wants till it is able to feed itself, except one thing. The calf requires at first absolutely nothing but milk, but the little plant cannot begin to grow until it is supplied with water from without, for the seed contains very little water. It is, therefore, a very compact mass of food-stuff. 
Consider next a root, like a carrot or a turnip, or an underground stem, like a potato. All these contain a store for the plant which is to re-start growing in the spring, therefore all contain proteid and starch, and perhaps a little fat. But while the seed must be small because it has to be carried away in some fashion to a distance from the parent plant, the root or stem, which in nature remains in the ground, need not be small. We therefore find that such roots and stems contain a good deal of water-the water which is absent in the seed.

Suppose we were on a sinking ship, and were only allowed to make up a small bundle to take with us into the lifeboat, we should take only the most precious things, should we not? Well, the annual plant is the sinking ship, and, as it can only give its offspring, the seeds, a small bundle, it is necessary that that bundle should only contain valuable things. Therefore, the seed contains a relatively large amount of proteid, which is the most precious thing; it often contains fat, which is the next.most valuable thing; and the rest is filled up with the cheaper carbohydrates. In roots, where size does not matter so much, there are fewer banknotes, that is, less proteid; but there is a lot of spending money - shillings and sixpences and coppers, heavy to carry but useful to have. The spending money consists of starch or sugar, 
CHAP.

which enables the plant to start growing very quickly in the spring.

Finally, let us look at the fruits. They are very different from either seeds or roots. The substances in the fruits are of no direct use to the seeds, they are given away as a bribe to persuade some animal to carry away the precious seeds to a distance from the parent plant. Look' at a bird pecking at a wild-rose hip. He pecks the nice red cover, which is sweet and pleasant. But as he pecks he breaks through the red cover, and the hairy seeds come out. They stick to his beak in an uncomfortable way, so he wipes his bill on the ground to get rid of them. In that way he plants the seeds, which would otherwise fall close to the mother rose and be choked by all growing together. The rose, therefore, practically says to the bird: "You carry my seeds away for me and I will give you some nice sugary pulp for your trouble."

It is like giving a boy a pennyworth of sweets to carry a message. But the rose has to be economical; it must provide for its own children, the seeds, first. It is as if the rose said to itself: "I cannot give the bird who carries my message for me proteid, because my own children need all I can give them. I cannot give him fat, because that is dear too, but I have plenty of starch and sugar, he can have that, and I will give him as 
well some flavouring, and colour the fruit-case a pretty colour, and then he will be quite content."

That is what is actually done by the rose, and is what happens in the making of most fruits. That is, they contain water, sugar, or sometimes starch, flavouring matter, but not much else. Generally, though they are a good addition to our food, they would not form a diet by themselves. But many plants, which in the wild state have very poor fruits, if they are cultivated and well fed, can be made to give a great deal more to the fruit, and thus render it more useful for man's food.

Now what does all this mean from man's point of view? Does it not mean first that the most important part of his plant food must be seeds, for it is only in them that he is likely to find much of the necessary proteid? Perhaps it may be said that the banana-eating Baganda, whom we read about in the first chapter, form an exception to this, but remember that the bananas which they eat have no seeds; the proteids which in the wild bananas went into the seeds, in the cultivated one go into the fruit pulp. Except where people are purely meateaters it is generally true that some kind of seeds, or a flour made from seeds, forms the chief part of their diet. For example, wheat, in the form of bread, forms the basis of the diet of many peoples, and rice of a great number more. Perhaps 
it may be said that we eat so many different kinds of things that wheat only plays a subordinate part in our diet. But if we think for a moment we shall see that bread forms part of all our meals, and though bread and water is not a diet that we should care to live on for long, yet we know that it is possible to live on it for a time.

The geologist, Hugh Miller, who from being a poor quarryman rose to be a great man of science, tells us, in the story of his life, that when he was a journeyman he and his companions lived entirely on oatmeal, in the form of porridge and oatcake. So long as they could get milk to take with their porridge they were quite content; it was only when the milk-supply failed, and they had absolutely nothing but the oatmeal, that they felt themselves a little hardly used. The fact that they did live upon it, however, shows that the seeds of the oatplant, without anything in addition, can supply man with the three necessary food substances, though they are poor in fat.

But though seeds furnish probably the most important part of man's vegetable food, yet some kinds of roots and underground stems are also very important. We saw before that yams, which are the underground stems of plants distantly related to our leeks, form the chief food-supply of some kinds of African negroes. Similarly, potatoes are 
very important as food in Ireland, but there they are of course helped out by other kinds of food. Though some kinds of roots are very nutritious yet, as a general rule, they are poor in proteid, and so must be used with other foods, and especially with some kind of seeds, such as cereals (wheat, oats, etc.) or pulse (peas, beans, etc.).

As to fruits, we find that, as a general rule, they are much more important in warm than in cold countries. We must not suppose that this is because fruits only grow and ripen in hot countries. On the contrary, what gardeners call the "small fruits " will only thrive in cool countries. Nowhere do strawberries grow as they. do in such countries as England where the summers are not very hot. In the high Alps, and in Norway and Sweden also, there is in autumn a wealth of berries-such as bilberries, cowberries, cranberries, and so on-which is quite peculiar to these parts, and is not even suggested in hot countries.

But while fruits almost satisfy the appetite of the inhabitants of hot countries, in cold countries they only form a dessert, an extra. There is so little in them but sugar and flavouring matter that they hardly count as real food, except in those countries where very little food is required.

In addition to giving man food in the form of seeds, roots, or fruits, the vegetable world gives 
him also a great number of flavouring substances, which are of great importance, especially when he lives largely on vegetable food; for this is often tasteless by itself. We have seen already that the

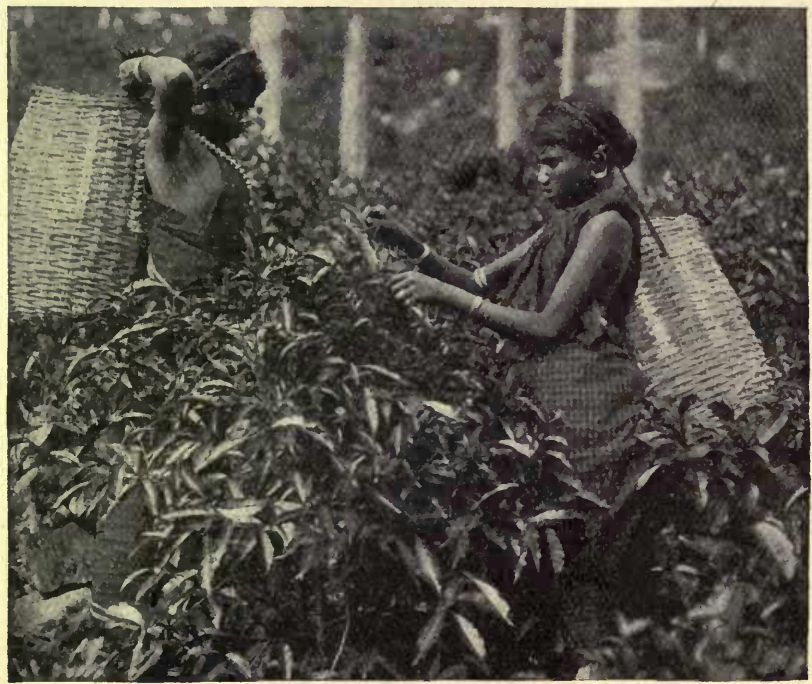

Fig. 30.-Picking Tea in Ceylon.

early Mediterranean eivilisation depended chiefly upon wheat, upon the olive which gave fat, i.e. olive oil, or upon sesame which also gave oil, upon the wine which gave a pleasant drink, and upon fruits, such as figs or dates according to the country. But flavouring plants, such as garlic, were added to these very early; and later the commerce 
between the Far East and the West largely began through the desire of the West to have the spices and the pepper of the East. We must not, therefore, forget these flavouring plants in speaking of man's vegetable food, though they rather help to render his food digestible and palatable, than act as food themselves. Nor should we forget such plants as tea, coffee, or cocoa, which yield stimulating drinks, used by all civilised people.

\section{CHAPTER XI}

THE CHIEF KINDS OF FOOD-PLANTS

WE must consider next the kinds of plants which give to man the most valuable seeds, roots, and fruits.

As regards seeds, two families are by far the most important, these families being the Grass family and the Pea family. It is not too much to say that man could not have spread over the globe as he has done, if it were not for the existence of these two families. Here and there, it is true, scattered over the different quarters of the globe, we may find small groups of men who owe little to these plants; but it is true for the vast majority, 
both for themselves and for their cattle, that it is the grasses and peas and beans that feed humanity. The leaves of many kinds of grasses, and of such members of the Pea family as clover and lucerne, form forage for the domestic animals, while the seeds of other kinds feed man himself.

Both families contain a considerable number of annuals, that is of fast-growing plants which throw all their energy into seed-making, and die of exhaustion as soon as their seeds are full-formed. In consequence, the seeds are big and plump and full of food material. Further, they are for the most part without the poisonous substances found in many seeds, which render them unfit for food; they only require cooking to form an important part of man's diet.

Let us stop just for a moment at this word " cooking," to ask ourselves why seeds cannot generally be eaten without cooking, while we often eat fruits raw. The explanation is found easily if we go back to the question of the contents of fruits and seeds. We saw that fruits generally contain sugar, while seeds generally contain much starch. Now starch is difficult to digest when eaten raw ; it is much easier to digest when it has been altered by the heat used in cooking. We do not generally, it is true, cook nuts, which are seeds full of starch; but then we eat very few nuts at a time. If we 
tried to eat many, we should be obliged tọ cook them. When man learned to live largely on seeds he had also to learn to cook his food, and that was a great step in advance.

It seems to us a horrible idea that people should eat uncooked meat : but yet, really, there is less need to cook meat than to cook vegetables. Cooked meat may be less, not more, digestible than uncooked, but there are many vegetables that are quite indigestible until they are cooked. Learning to cook must have taught man many things. It meant the beginning of pottery; it meant the development of skill and patience; as well as of many other useful qualities.

More than that, the degree of ease with which the different kinds of vegetable food can be cooked must have influenced man greatly, in the early days, in deciding what kinds of plants he would cultivate. The seeds, which we call pulse, such as the different kinds of peas and beans and lentils, are generally more nutritious than the cereals like wheat and rice and oats. We should imagine then that pulse would be cultivated more generally than the cereals; but we know that it is the contrary which is true. There were some peoples, the ancient Mexicans, for instance, who lived very largely on pulse, but these races were never so numerous as the peoples who lived chiefly on cereals, such as wheat and rice. 
The reason is that the cereals are cooked more easily and are more digestible, and, therefore, better suited to be eaten in quantity.

In an earlier chapter we saw that there were three great centres in the world where agriculture began and cultivated plants were produced. It is interesting to consider what were the chief seedproducing plants in these three places. In the great agricultural area at the eastern end of the Mediterranean, the great seed-producing crops were first barley and later wheat. In the warm parts of America, the great food-plants were beans and Indian corn. In the Far East, though wheat was introduced into China very early, the most important plants were rice and millet.

Now of all these food-plants wheat seems to be the best. It contains more nitrogen than rice or maize; it is more digestible than beans. It has one great advantage over the other cereals in that it contains a large amount of a sticky substance, which enables it to be made into light bread easily. We all know that oatmeal, for instance, cannot be made into a proper dough like wheat flour. It is this power of forming a dough which makes wheat flour'so digestible.

Now it is rather interesting to notice that so far in the battle of civilisation the wheat-eaters -re, won. Wheat was first grown in the Mediter- 
ranean area, but it soon spread. All the nations which got their civilisation in whole or in part

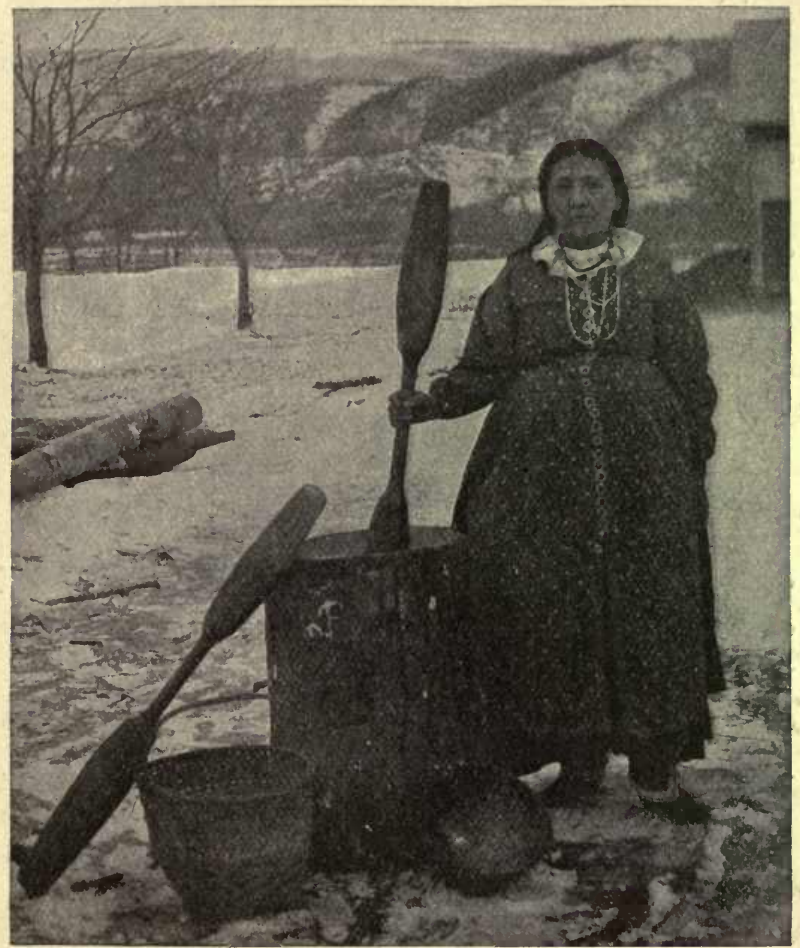

FIG. 31.-North American Indian Woman pounding Indian Corn, After pounding, the meal is sifted through the baskets, the finer parts being made into bread and the coarser into hominy.

from the Mediterranean region, learnt also to grow and to eat wheaten bread. The process was a slow. one. The story about Hugh Miller reminds us 
that it is only comparatively recently that wheaten bread became the usual food of the Scottish people, and in many parts of Germany a great deal of rye bread is eaten still. At the same time it is generally true that the peoples of Europe are wheateaters; they eat wheaten bread when they can.

When the Spaniards conquered America, the conquest meant practically the crushing of a beanand maize-eating people by a wheat-eating one. All the countless fields of wheat, which are now to be seen in America, show how completely the Europeans took their love of wheat with them to America.

Hitherto also it has been true that the wheateating peoples have, on the whole, been more energetic and done a bigger share of the world's work than the rice-eating people of the East, whose diet is poorer and less digestible. It is one of the interesting questions which the future must decide, whether the Japanese and the Chinese will continue to be largely rice-eaters, or whether they also will learn our habit of eating large quantities of wheaten bread, and if they do learn this, whether it will make a difference in the kind of work they do.

But we must go back to the important seedproducing plants. Probably wheat is the most important of all, but there are a great number of others. In the Old World we have as other cereals 
in temperate climates, rye, barley, and oats. In hot climates rice and millet are important. The New World has given maize, or Indian corn - a very important plant now widely distributed. All these are annuals and all require considerable skill to be grown properly, so that it is only relatively advanced people who can grow them on the large scale.

Next to these the most important seed-bearing plants are the different kinds of beans and peas. These are not of great importance in a country like our own, where wheat is the chief bread plant and everybody can get a certain amount of meat, but they are very important in countries where little meat is eaten, and especially where such cereals as rice are used instead of wheat. The reason is that beans and peas contain, as we have already seen, a great deal of proteid, and, therefore, they can be used partially to replace meat.

If we were to travel down through France, for instance, one of the things we should notice would be the quantities of different kinds of beans that the people grow in their gardens. They grow them as we grow potatoes, and they eat them at one meal in the day at least just as we eat potatoes. If we travelled on into Spain we should find there that a kind of pea, called the chick-pea, is grown everywhere, and largely takes the place of meat.

In the same way in China and Japan, where 


\section{TILLERS OF THE GROUND CHAP.}

the people get very little meat and where they live largely on the rather poor grain rice, they eat a great quantity of what are called soya beans. The rice without the beans would not be enough

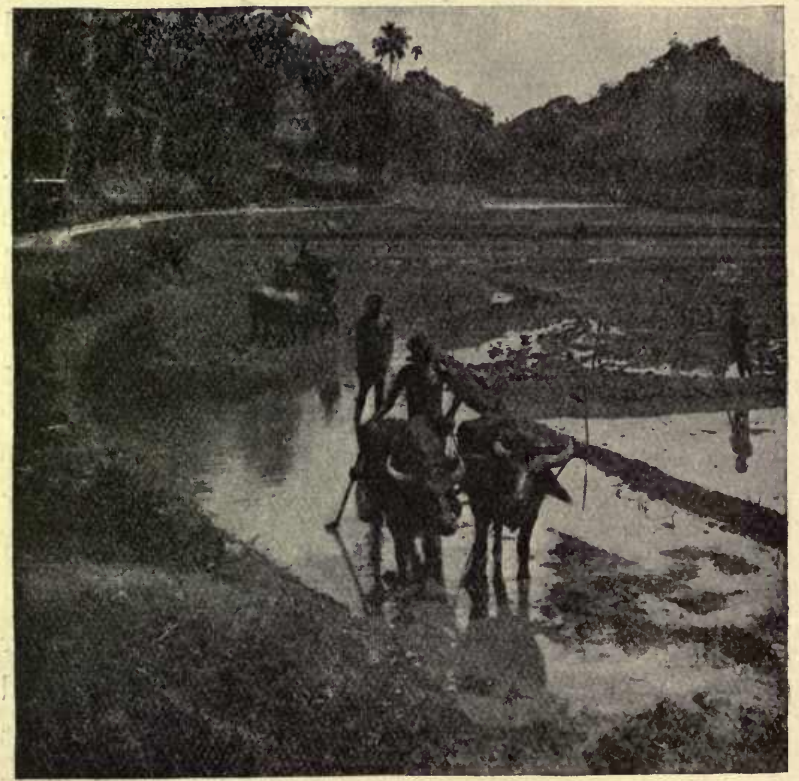

Fig. 32.-A Rice Farm in Ceylon.

for them-they would not get enough proteid. These beans also contain a large amount of fat, which is important because rice has hardly any fat. Thus beans and rice together make a good diet, though neither would be sufficient separately. 
A considerable number of other seed-producing plants are also cultivated, but perhaps we need only mention buckwheat, which is not a true grain, but is used instead of a grain in some places, because it is easily grown, even on poor soil.

When we come to consider the plants which man cultivates for the sake of their underground parts, we find that no two families stand out as do the Grass family and the Pea family among seedproducing food-plants. There are, however, a great many families which include one or two useful plants.

If we begin with cool climates like our own, we find that the members of the Cabbage family are often important, either directly or indirectly. Thus, if it was not for the different kinds of turnips and swedes, farmers could not keep their sheep alive during the winter, and we could not get mutton to eat. That is, though perhaps turnips do not matter a great deal to us directly, they matter a great deal indirectly.

More important to us is the potato, which is the underground stem of a plant of the Deadly Nightshade family. The potato is a plant which likes a cool climate, and requires a great deal less sun than grain does. It is this which makes it so useful a plant in Ireland, where the damp prevents wheat from ripening. It is very interesting to 
notice that the potato belongs to a family some members of which are very poisonous. Even the potato itself, if the tubers are allowed to become green by being exposed to the air, becomes unwholesome and even dangerous. That is why potatoes have to be "earthed up" carefully, and should always be stored in dark places.

In hot countries, our potato is replaced by a plant something like it, called the sweet potato, which really belongs to quite a different family, the Convolvulus family.

Other plants which in hot countries take the place of our potato in supplying the necessary starch, are manioc and yams. Manioc is an interesting plant. It is a shrub with thick, fleshy roots, which grows easily and rapidly; so quickly, indeed, that its produce is said to be six times that of wheat. It belongs to the Spurge family, and just as other plants of the potato family are very poisonous, so plants of the Spurge family are also often very poisonous. Even the manioc plant itself is poisonous, and this is a curious and interesting point.

We saw before that cooking is generally more necessary for plant foods than for meat, because, without cooking, plant food is often very indigestible. There is, however, another reason for cooking vegetable food, and that is that uncooked vegetables 
are sometimes poisonous. We have all eaten apples, and we have all been told, since we were quite small, that it is not wise to eat apple pips. Suppose we try one, however; it will not do us much harm, and it is an interesting experiment. If we nibble it slowly between our teeth, we find that our mouths become filled with a nasty-tasting substance. If we eat two or three pips, this nasty taste will perhaps remain in our mouths for several hours, and give us a very uncomfortable sensation. But when apples appear on the table at dinner-time, after having been baked or stewed, we find that the pips have no taste at all, and do not disagree with us. This means that, in cooking, the heat of the fire has driven off the poison.

Now, it is not at all uncommon to find that parts of plants contain poison, which protects them against the attacks of plant-eating animals. But man is cleverer than the animals, and he learnt long ago that poisons could often be driven off by heat. In Brazil the people live very largely on manioc, and it is full of a deadly poison. What do they do? Well, the roots, the edible parts, are first carefully scraped, then the interior is crushed into a kind of flour, and carefully baked in thin layers, so as to drive off the poison. Prepared in another way manioc makes tapioca, which we eat 
in puddings without ever thinking of the poisonous plant from which it comes.

Another kind of plant furnishes the yams on which the natives of some warm countries largely depend, and yams again are not wholesome unless they are cooked carefully.

In general, we may say that underground stems and roots supply man with a large part of the necessary carbohydrate, but they are deficient in proteid. In cold countries, therefore, they are supplemented both by some kind of seeds and, where possible, by meat. The meat gives the flavour necessary to make the roots digestible and pleasant to the taste. In warm countries, where meat is less necessary, some of the strong vegetable flavouring matters are used usually to make up for the want of taste possessed by the vegetables themselves.

In regard to the fruits cultivated by man, we may notice first the great importance of the plants of the Rose family. This family gives us apples, pears, peaches, apricots, plums, cherries, strawberries, and many other of the fruits of warm or cool countries, all of which are wholesome and pleasant, though they do not supply a large amount of actual nutriment. Then we have in warm countries the vine, a plant of great importance. In this country we think of wine as only a luxury, but in 
countries where less meat is eaten than here, light

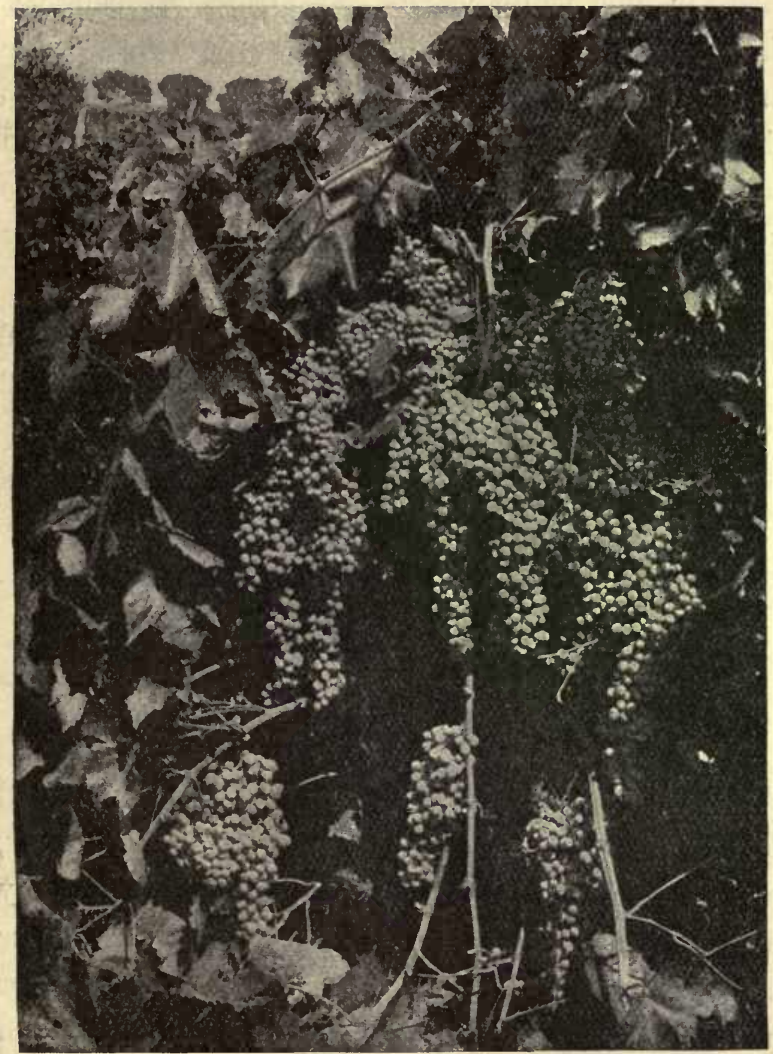

FIG. 33. - The Vine with Grapes.

wine is of great importance, and seems to enable the people to live on less food than they would otherwise require. 
We have already spoken of the great importance in hot countries of such fruits as bananas, dates, and figs, all of which contain a considerable amount of food material. We must remember also that vegetable marrows, pumpkins, cucumbers, and so on, are all fruits to the botanist, and these are very useful in warm countries as important additions to the diet.

The fruit of the olive tree, again, as we have seen, yields the kind of fat which is most suitable to people in hot climates.

\section{CHAPTER XII}

\section{IMPROVING CULTIVATED PLANTS}

WE have already seen that most of our cultivated plants are very old, and that with regard to many, we do not even know from what wild plants they were derived. If, however, the beginnings of these useful plants are very old, we know, on the other hand, that great improvements in them have been made in relatively modern times. Nearly all our cultivated plants now occur in a great number of varieties, fitted for different soils or different countries, yielding different kinds and amounts 
of produce. It is the existence of these numerous varieties which helps to give the modern so many advantages over the ancient farmer, for he can find some variety fitted to grow on almost any kind of soil.

But improvement has not only shown itself in the increasing number of varieties; it has also shown itself in a general improvement in the different plants. In some cases, especially in fruit trees, where many of the improvements have been very recent, it is easy to prove that this is so. But, though it is less easy, we can also prove that the seed-producing plants have improved greatly since the days when they were first cultivated.

There is one rather interesting way in which we may prove this. We have already seen that one of the difficulties in finding out what men did in the very early days is that those were the days before writing had been learnt, and man therefore could leave behind him no written memorials to be read by the generations to come. Early man did, however, leave behind him memorials of a sort, and these memorials men of our times have learnt to read, after much stumbling and hesitation.

Ages and ages ago primitive man lived in dwellings made of piles at the edges of the lakes in Switzerland and Italy. Remnants of those ancient dwellings still remain, and from these remnants the 
life of these ancient peoples has been reconstructed. Though they had only stone tools, these people managed to till the ground and to sow wheat and peas. Though they are long since dead and gone, yet some of the seeds which they dropped have been found, and these have been examined carefully. Even ears of wheat and barley have been preserved, and from these we know that the grains these people cultivated were smaller and poorer than those our farmers now grow. The ears were narrower and shorter, the individual grains smaller, so that the yield of the little plots which they cultivated must have been scanty.

By infinite care a Swiss man of science has succeeded in following down through the ages the different kinds of grains in Switzerland. He has shown that the first poor kind of wheat lasted down to the Roman period, when it disappeared for ever. He has shown also how other and better varieties appeared gradually, replacing the old. Thus, by the time the ancient inhabitants of Switzerland had learnt to make tools of bronze instead of stone, they had also learnt to grow better kinds of wheat, especially that called spelt, varieties of which are still grown in parts of Europe. They had also added rye and oats to the poor wheat and barley of the early days.

Much the same thing is true of their peas and 


\section{xII IMPROVING CULTIVATED PLANTS 143}

beans. In the remains of the Stone Age, a few traces of a small round garden pea have been found, but it was not until the Bronze Age that this pea seems to have become abundant. In the Bronze Age garden beans appear for the first time, but these were only about half the size of our beans. Not until the time of the Romans does a larger and better bean appear.

When we get down to the time of the Romans, it is easier to show that at least the idea of improving cultivated plants was present to the minds of the people who cultivated the ground. Thus Virgil says :-

I've seen the largest seeds, tho' viewed with care,

Degenerate, unless th' industrious hand

Did yearly cull the largest.

This shows that he had noticed that the grains of corn were not all of the same size, and that if even the level already attained was to be kept up, it must be by carefully picking out the best grains to serve as seed-corn. In much the same way, Celsus, who wrote nearly a hundred years after Virgil, but still more than eighteen hundred years ago, says: "Where the corn and crop is but small, we must pick out the best ears, of corn, and of them lay up our seed separately by itself."

It was not only among the Romans, however, that the farmers saved the best seed for sowing. 
Very early an Imperial Edict in China recommends that specially large seeds should be sown, in order that a stock of plants producing such seed might be obtained. It is even said that a particular kind of rice, called the imperial rice, was first obtained by the Emperor Khang-hi, who, walking in the fields, noticed a particularly fine rice-plant, and had it brought into his garden. Here it was cultivated and improved, and from this plant a new variety of rice arose, which proved very hardy and very useful.

We might go on to show by quotations from early English authors that the method of improving plants, by selecting the seeds of the best plants and sowing these, has been carried on for a long time in England also. What has been already said, however, is enough to show that if our cultivated corn and peas are much better than those grown by the first farmers in Europe-the people of the Stone Age-then this difference is largely due to the steady perseverance of generation after generation of cultivators. But for a reason which we shall have to consider directly, it was not until the eighteenth century that great progress was made.

Some of the stories about the discovery of good kinds of cultivated plants read almost like fairytales. Thus, a farmer called Hunter, walking in his fields in East Lothian, in Scotland, many years 
ago, noticed a few ears of wheat which seemed a specially good kind. He carefully pulled the ears when they were ripe, kept the grains separate, and sowed them in a special plot. They grew into plants which had the same good qualities as their parents, and in a few years there was enough seed to put the new variety on the market. Other people found it as useful as Hunter did, and it spread over Scotland and England and even into France, and is called Hunter's wheat to this day.

There is another story, even more curious, of a farmer who, for some purpose or other, climbed on the top of a corn-rick. When he came down he found that an ear of corn was sticking to his coattail, and that this ear seemed to be specially fine. He saved the seed, sowed it separately, and after several years had the satisfaction, like Mr. Hunter, of being godfather to a new variety.

This is one way, then, of making new varieties, by merely picking out from among thousands of ordinary plants the one or two which chance to be exceptional, and breeding from these. This is a slow process, and it was by such a slow process, for the most part, that improvements in seed-producing plants were carried out down almost to the second half of the eighteenth century. Since then a very much quicker, though very laborious, method has been more and more adopted, with the result that 
a tremendous number of improvements have been made.

To understand this new method we must go back a little. We have already seen how the Assyrians and the Arabs carried the pollen-bearing branches of the date-palm to the fruit-bearing trees, even though they did not understand clearly the meaning of pollen. The idea of taking away the stamens, or little threads, the swollen tops of which produce the pollen, from a flower which has both stamens and seed-pods, and bringing to it instead pollen from another flower, was much less likely to occur to people ignorant of botany, but yet we have reason to believe that this was done by the Japanese and Chinese very early, and was also to some extent done by the Romans. When this is done, and when afterwards the seed sets, this seed may grow into plants different from both parents. Very often also the seedlings differ a great deal among each other. This crossing, as it is called, is then a way of producing a number of varieties in cultivated plants.

In the seventeenth century gardeners in Europe, and especially in Holland, began to cultivate tulips and auriculas, and to produce all sorts of varieties. If we had time we might tell all sorts of curious stories about the tulip mania-how tulip bulbs were sold for their weight in gold; how men 
schemed, and quarrelled, and robbed, to get possession of precious kinds; how the bulbs had to be watched night and day to prevent the offsets being stolen. These and a great many other curious stories we might tell, but at present it is sufficient for us to know that these wonderful tulips were produced by crossing. The fact was, however, kept a profound secret, and it was not till nearly a century afterwards that crossing came into general use as a means of improving cultivated plants. The "tulip mania," as it was called, was as foolish as most manias, but it did one very important thing - it taught gardeners in general how they might improve their plants; how they might apply the knowledge that the botanists had been slowly and carefully collecting.

In the next chapter we shall have to consider exactly what crossing means, and how it is carried out. In concluding this chapter let us just notice what selection and crossing have done in the case of one cultivated plant, the wheat plant.

Wheat, as we have already seen, was originally a cultivated plant of the Mediterranean zone, where the winters are mild and wet, and the summers hot and dry. The plant there was always sown in autumn, grew through the warmth and wet of winter, and ripened in the bright sunshine of summer. But it will not stand a very severe 
winter, nor does it do in a very hot dry climate, or

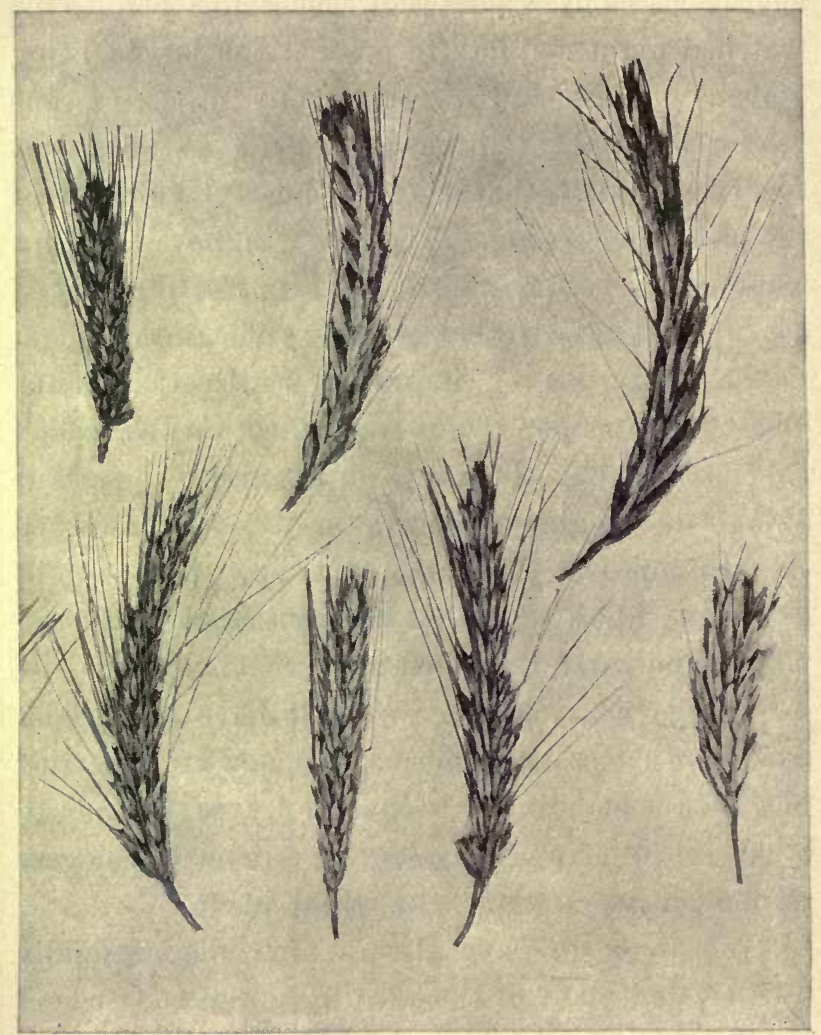

FIG. 34.-Different Varieties of Bearded Wheat.

with too long spells of dry weather. When it spread over the greater part of the earth, then, it became necessary to have kinds fitted for all the 
different climates. An enormous number of varieties have been produced to meet these needs. It would not be difficult, one author tells us, to name some thousands of different kinds of wheat. The same author describes in detail sixty kinds, which he says are the most important kinds for the farmer in England and France. Things have altered a good deal since the Stone Period, when there were one common kind and four other rare kinds!

The sixty kinds most useful in England and France have all their special properties, and man has to learn, by slow and sometimes painful experience, which kind is most useful in each particular. situation.

For instance, there is rather an interesting little story about spring wheat in the eastern parts of France. During the terrible war of 1870-71 some of the provinces were so ravaged by war that it was impossible for the peasants to sow their wheat in autumn. By the spring of 1871, however, the war was over, and hope began to revive among the people. One of the most wonderful things, perhaps, in the history of the world is the way in which the French people set to work to repair the fearful destruction which that short war made. Pasteur, the celebrated biologist, was one of the great Frenchmen who set themselves the task of making France great again, not on the field of 
battle, but in the nobler fields of knowledge; and there were many others.

But before a new France could be slowly built up, the people must have bread; the land swept bare by the two armies must be ploughed and sown. The seed-corn which the peasants had saved had either been eaten in their time of dire distress, or was useless now the springtime had come. So one of the many committees for helping the unfortunate, which had been founded at this time, distributed spring corn (that is, corn which could be sown in spring) in the ravaged provinces. They knew that this spring-sown corn flourished in parts of England, and they hoped that it might do the same in France. But, alas! they had not noticed the slight difference in climate, the fact that the hot dry summer comes earlier in France than in England, and is both hotter and drier. The hot dry weather came before the wheat had had time to make its growth, and the poor peasants had to stand by and see the empty ears in their fields wither for want of rain. While this happened in France, in England the same wheat grew steadily all through the early part of the summer, which was damp, and ripened beautifully in August.

This little story appears in a French book on the best kinds of wheat, and the only comment the author makes is that this was a lesson to French 
xII IMPROVING CULTIVATED PLANTS 151

cultivators in regard to the best times for the sowing of wheat. We must not think from his saying only this that he did not feel the deepest sympathy with his poor fellow-countrymen, all but crushed beneath the weight of their successive misfortunes. He writes as a man of science, and as such he knows that it is useless to lament over such calamities - the part of the wise is to learn how to prevent them in future.

This is the heroic courage which science teaches, not the courage which is only of use on the field of battle, amid the flying of flags and the beating of drums, but that infinitely more precious quality which enables man to see all the results of his work destroyed, and in place of simply giving way to grief and depression, to take from the experience the conclusions which will be valuable to others in future. It is this heroic courage which makes man great, in spite of all his weakness and pettiness, and one reason why science is so valuable to humanity is that it is the love of knowledge more than anything else, which leads to the development of this particular kind of courage. 


\section{CHAPTER XIII}

\section{EXPERIMENTS IN PLANT-BREEDING}

WE saw in the last chapter that cultivated plants have been improved very greatly since-agriculture began, and that most of them now occur in a great number of varieties. We saw also that in the first place improvements were brought about simply by picking out the best plants and sowing their seeds separately. A good deal of improvement was brought about in this way, but it is a slow and somewhat uncertain method.

We saw next that for the last hundred and fifty years or so another method has been more and more adopted. This consists in crossing different kinds of the same or similar plants, these different kinds being sometimes obtained from countries widely separated from one another. The first result of this crossing is often to produce a number of different kinds of seedlings. The next step is to pick out the suitable seedlings, and, by care and cultivation, helped often by fresh crossing, to produce entirely new plants.

When making new varieties was merely a matter of picking out good kinds which appeared by 
chance in the fields, this could be done by ordinary farmers. On the other hand, when these new kinds have to be made deliberately by crossing and then long breeding, there is more work than the ordinary farmer or gardener can undertake. Farmers and gardeners have their daily work to do; the delicate operations by means of which new plants are now made, require more time and care than they can give. We find, therefore, that now, in addition to the people who grow plants for the sake of their produce, there are other people who grow them for the sake of making new plants, or of producing the kinds of seed best suited to particular conditions.

Sometimes these people are nursery-gardeners, who, instead of sending lettuces and cabbages to market, devote themselves chiefly to supplying other gardeners with the best kinds of seeds. There have been in England a number of famous gardeners of this kind, for the production of fine kinds of plants and of farm animals has for long been a speciality of the English people. It is one of the ways in which we show our practical cleverness.

In addition to the gardeners, however, a number of other people have worked at this subject, both in this and in other countries. In England especially, there have never been wanting people willing to give their time, their money, and their labour to the experimental study of agriculture and of 
methods of plant-breeding. Some of these experiments have had for their object the finding out of facts which would be directly useful to the farmer, others have been undertaken in order to learn more about the nature of plants.

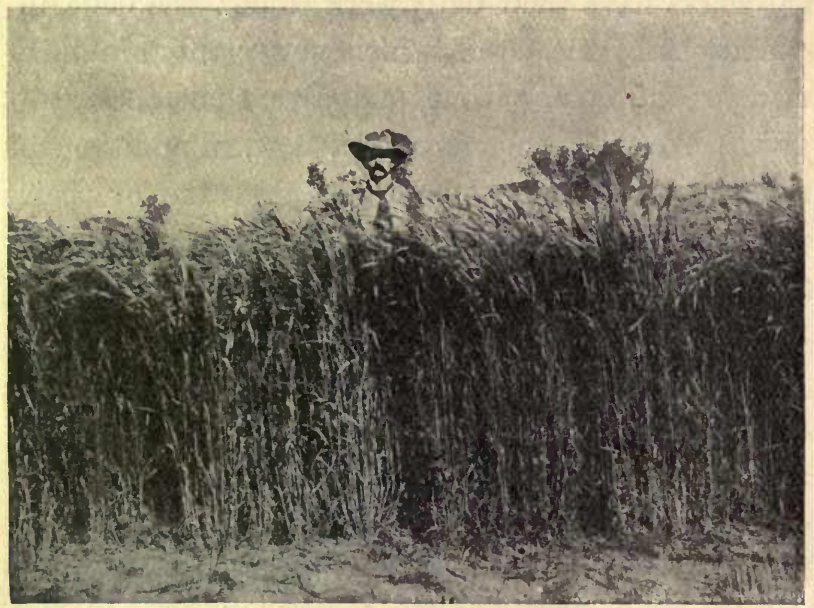

G. 35.-A Field of Giant Wheat in the New Mexico Experimental Station.

But we must not suppose that the latter are really of less use than the former. It has happened again and again that experiments which have been undertaken merely to solve a point of scientific interest have led to the discovery of facts of great practical importance. In the long-run all knowledge is useful, for experience shows that it is the people 
who are interested in knowing who are successful in doing.

We shall consider here, then, first some experiments on breeding plants which as yet have had very little practical result. They are an attempt to wrest one of her great secrets from Nature-the secret as to the relation between one generation of plants and the next. When we know that secret, we shall be able to do almost what we will with our cultivated plants and animals, to do it directly, and not with the stumbling slowness which is still the method of to-day.

Meanwhile the work of the Abbot Mendel, to which we shall refer directly, is a beautiful example of scientific work, undertaken out of pure love of knowledge, and carried out with that perseverance and single-mindedness which make genuine scientific work truly great, whatever its practical result.

Before speaking of Mendel's experiments, however, let us stop to say a few words about the human aspect of scientific work. It is often very difficult for us to understand what scientific work means in the life of the man who does it. We read that so-and-so worked for perhaps ten or twenty years, and at last he arrived at such-andsuch results, but we do not realise clearly that it was a human being like ourselves who did all this. We do not see clearly that it was a man who got 
tired as we get tired, who felt depressed at failure as we feel depressed, who in his inmost heart loved short cuts as we all love them, and had to learn slowly, as we all must learn, that short cuts are generally longer than the weary straight road.

When we read that so-and-so produced some useful new plants, or found out some interesting facts, we are apt to think that it must.have been nearly as easy for him to make the new plants or to get the new facts as it is for us to read about them. Before going on, then, to some facts about cultivated plants and how they have been obtained, let us hear a little story about one piece of work and how it was done. It is not a story about plants, but the principle is the same, for it is a story of scientific work, and in principle all scientific work is alike.

There was once a doctor-he afterwards became a very famous doctor, but at this time he was just beginning his work. He was not at all satisfied with the way in which doctors treated certain kinds of accidents, and he wanted to improve these ways. For a long, long time he worked, helped by his students, in his workroom, trying to find a better way. At last, after long search, he thought he had found what he was seeking.

At this time he had in his hospital a railwayman who had been hurt-badly hurt-in an accident. 
The doctor went to the railwayman, and said to him that he would like to try the new method on his injury. The railwayman was quite willing - he was greatly interested, indeed, for the doctor explained to him just in what way the new method would be better if it succeeded. But if the method failed there was danger. Somebody must always stay by the bedside of the patient, night and day, to make sure that nothing went wrong. Even if a doctor could be got in three minutes it might be too late; somebody must be always there. Therefore the students - remember they had their daily work to do as usual-arranged to take it in turns to watch by the man's bed night and day, with all their instruments ready, so that if anything went wrong, it could be put right instantly. For ten days, the doctor said, there would be risk. For ten days the man must never be left for an instant.

Nine days passed, and everything went well. Every morning the doctor came, and every morning the patient said, "It's holding, doctor," for he was as keen as anybody on the experiment. But, alas! during the ninth day something went wrong. A watchful student was at hand, and no harm came to the brave patient-but the doctor had failed.

What he felt, nobody knew; but one of his students says that he came into the lecture-room next morning exactly the same as usual, and he 
said, "Gentlemen, this experiment has failed. We must begin over again."

Success came afterwards; it must come with such a man, but this same student says that he never forgot the courage and the dignity of that little speech. "We have failed; we must begin again." Is not man truly great when he can say that, when he can begin again-begin the very day of his failure?

Now in the short accounts of scientific work for which alone we have room here, we can only speak of the results, of the successes, but we must not on that account think that there was no failure. Just as we fail, fail constantly, so all the great men have had times of failure. What makes them great is that they have had the courage to begin again, which we do not always have. The love of knowledge will carry man farther than almost any other quality; it carries him through failure to victory, and the victory is often not for himself but for those who live in the future.

With this little story in our minds to help us to understand what scientific work means in the life of the man who does it, let us cross the Channel and travel across the continent of Europe to Austria, in order to learn something about the experiments of the Abbot Mendel.

Mendel was born in Silesia, and was the son of 
country folk, so that from boyhood he was probably interested in country things. But he was a clever boy, and as his parents were not poor, it was decided he should go into the Church. He studied science at Vienna, and afterwards became Abbot of Briinn, a town in Moravia in Austria.

Though he did some teaching at one time, we must suppose that Mendel had a good deal of leisure, and his monastery had evidently a large garden. He was especially interested in crossing, and what he wanted to find out was exactly what happened when plants were crossed.

We have already spoken of the meaning of crossing in a general way. Let us note just what it means in the case of one particular plant. We may find in a garden tall peas, which need to be sticked, and short peas, or dwarfs, which do not need to be sticked. Each pea-flower, whether borne on tall or dwarf peas, contains both stamens, or pollen-containing organs, and a seed-pod. Usually the pollen from these stamens falls upon the seedpod of the same flower. That is, the flower is what is called self-fertilised. But suppose we take away all the stamens from the flower of a dwarf pea, and drop carefully on the top of the seed-pod some pollen from the flower of a tall pea, then we may say that we have crossed the dwarf pea and the tall pea. 
The next point is, suppose we sow the seeds from the pod formed in this way, shall we get tall peas or short peas? Or shall we get both short and tall peas? That was the kind of question that Mendel set himself to answer. Gardeners and others who work at these questions find it convenient to have a word to signify the plants which result from a crossing. When we go to a flower show we quite often find a flower or a vegetable labelled so-and-so's new hybrid-rose or new hybrid-cabbage. The word hybrid means that the plant has been produced by crossing two varieties of plants.

Using this convenient word "hybrid," then, we may state more exactly what Mendel wanted to do. He wanted to cross two kinds of plants, differing from one another in one or a few clearly marked features, and then to sow all the seed obtained in order to try to find out the exact proportions in which the parent plants would appear in the hybrids.

But we are not really so very much concerned here as to what he wanted to find out, as to understand what he did, in order to understand what crossing and breeding means.

The first thing was to find suitable plants for his experiments. After some time he decided that the Pea family was the best, and after growing 
different kinds of plants for some time, he decided that the garden pea was the best of this family for his purpose.

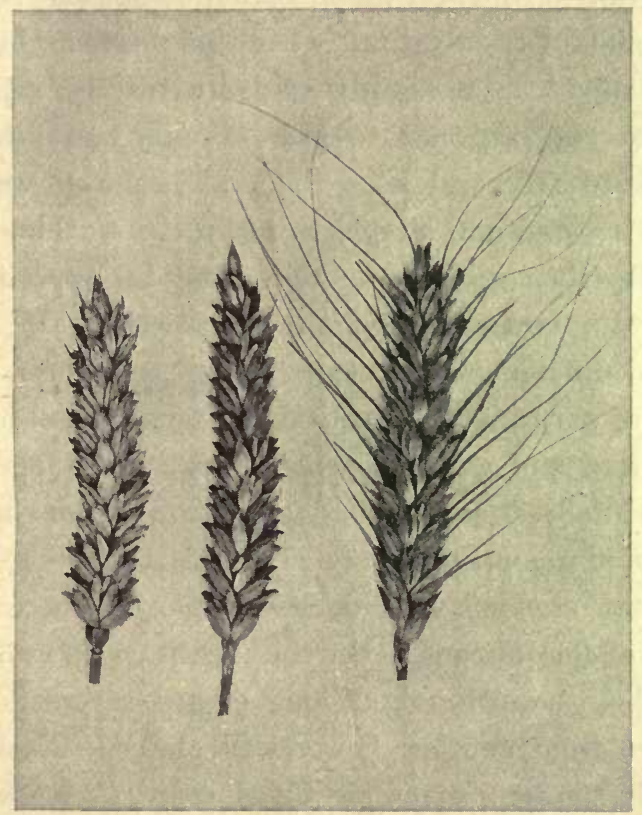

FIG. 36.-The crossing of different kinds of Wheat. The middle figure represents a hybrid form produced by crossing the kinds shown to right and left.

But though these experiments were carried out about fifty years ago, there were even then a great many different kinds of garden peas. There are still more now. Mendel got from a seedsman thirty-four 
kinds of peas, and grew them all for two years, to see which suited him best. Of these he decided that twenty-two kinds were suitable; these twenty-two he grew during the whole period of his experiment. We should try to think what this means. Mendel tells about it so simply and so naturally, that one would suppose that to grow twenty-two different kinds of peas and keep them all separate was the most natural and simple thing in the world.

He then goes on to tell about his experiments after the two years of preliminary work. He made seven different sets of experiments, and these seven sets of experiments involved the fertilisation of two hundred and eighty-seven flowers. Each of those two hundred and eighty-seven flowers was opened while it was still in bud. From each of those buds the ten stamens were delicately picked out with a pair of fine forceps. On the seed-pods of each one of those two hundred and eighty-seven flowers, pollen from another flower was placed. Each one of the flowers so crossed was then covered up so as to prevent insects bringing any other pollen to them.

This was the beginning of Mendel's experiment. It was also only the main experiment, and does not include all the extra observations that had to be made to be sure that all was going right. He speaks quite simply of examining carefully ten 
thousand plants to be sure that his experiments were not being spoiled by bees visiting the flowers and carrying strange pollen!

From the two hundred and eighty-seven flowers that he crossed Mendel got a great deal of seed. This seed was very carefully sown, every grain of it, in carefully marked beds. The plants raised in this way were allowed to fertilise themselves, and their seed again sown. This was repeated for four, five, or six years, the peculiarities of the plants raised each year being observed very carefully, and an exact count kept of the numbers of different kinds of plants.

We cannot stop here to explain exactly the results Mendel got, one or two points only can be mentioned. Thus in the experiments of crossing tall and short peas, he found that the hybrids, that is the plants obtained by crossing, had all long stems, longer even than that of the parent longstemmed plant. This is a very curious point. But when their seeds were again sown, it was found that in the next generation some of the plants were short-stemmed, i.e. were like their grandmothers, and others were long-stemmed like their parents. The proportionate number of short and long stemmed plants was also always constant. There is no doubt that Mendel's experiments are very important in connection with explaining 
In the first place, living in California, he enjoys more advantages of climate than European gardeners. In Holland, in England, in France, etc., the climate is much less favourable, and, therefore, gardeners have had many difficulties which do not present themselves in California. Secondly, for a variety of reasons, Burbank has been able to do his work on a very large scale, and that enables him to get results faster than those who have had to work with fewer advantages.

Let us begin with the very simple little story of the Californian poppy, which at least shows the methods employed.

In California a pure yellow, wild poppy grows abundantly all over the hillsides. Looking at a great number of these wild poppies one day, Mr. Burbank noticed one that had a crimson line on the yellow petals. This plant was carefully transplanted, and grown by itself in a nursery lued. At the end of the flowering season its seeds were saved, and these seeds were sown in a special bed. When the seedlings flowered in their turn the next season it was found that some had a slightly wider red band, while others again were pure yellow. The pure yellows were what the gardeners call "rogued," that is, ruthlessly pulled up and burnt, while seeds were saved from those with the broadest red band. This process went on for many genera- 
tions, the plants with the reddest flowers being chosen each season and the others rejected. In the long run a pure crimson poppy was produced in this way.

Very similar to this is the story of the Iceland poppy, of which several garden varieties were

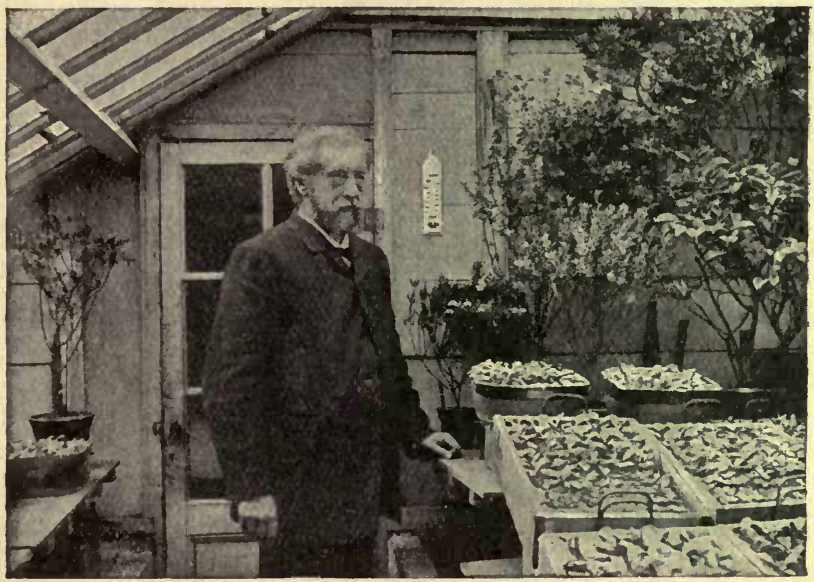

FIG. 37. - The Botanist, de Vries, in his Greenhouse.

produced by Miss Gertrude Jekyll, an English lady much interested in plants. Miss Jekyll grew a plant of the yellow Iceland poppy in her garden, and as it was a new garden flower, she sowed a great deal of the seed. The flowers of the seedlings were not all quite the same colour; some had a slightly orange tint. By selecting the seed care- 
fully, for several years, white, lemon, yellow, and buff varieties were obtained, and these varieties are now grown in every garden.

Here is another experiment, rather a pretty one, which was carried out by the great Dutch botanist called de Vries. He was out one day on an excursion in Holland, his native country, and he had, as he puts it, the great good-luck to find two "fourleaved" clover plants. Perhaps somebody here has looked for these plants without de Vries' good fortune. At least, we all know that these plants, like " evenleaved" ashes, bring good-luck to the finder. Some of us, perhaps, if we have never found a four-leaved clover have found the commoner " even ash." We know that if a girl finds such an ash, she has only to go out into the road, singing-

An even ash I now possess, new plucked from the tree, The first young man that I shall meet, my own true love shall be,

and then she will be happy ever after, just as in a fairy tale.

Well, it is not probable that de Vries wanted to use his four-leaved clovers for magic, either black or white. Let us see what he did do with them.

He brought the precious plants home into his garden, and there cultivated them for "three long years," says the criginal. He had the satisfaction 
of finding that as a result of his care the number of leaves with four parts increased.

He then collected the seed of the plants and sowed it. He got a number of plants which showed a slight increase in the number of leaves with extra parts. Out of this bed he picked out the four plants which had the highest number of four-partite leaves and saved their seeds. All the other plants were destroyed. He went on in this way for nine generations.

The results were curious. In the plants with which de Vries began there were many three-partite leaves (that is the usual kind), several four-partite ones,

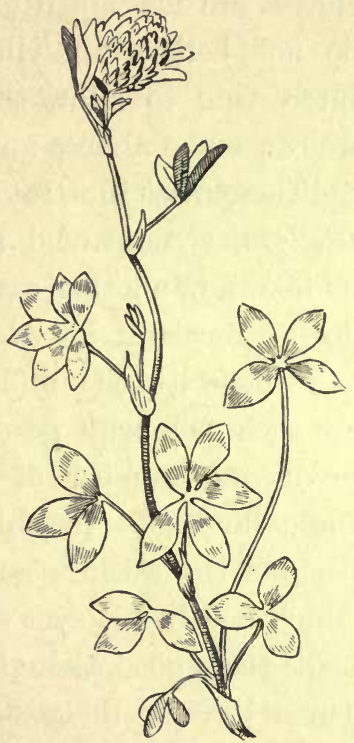
FIa. 38.-A piece of de Vries' Clover, with four-, five-, and six-partite leaves. and one with five parts. By going on always taking the seeds of those plants with leaves having more than three parts, he succeeded in producing clover plants with four-, five-, six-, and seven-partite leaves. In the end his clover bed contained plants the leaves of which had mostly five 
parts. There were always a few three-partite leaves, as well as four-, six-, and seven-partite ones.

Perhaps somebody will say that five-leaved clovers are not much use, especially for people who do not believe in "luck." But is it not rather interesting to know that with time and patience we can make almost any plant we want?

These cases illustrate what can be done by simple selection, accompanied by careful cultivation. Let us take now another case to illustrate what crossing does. Burbank has done a great deal of experimenting with the different kinds of lilies, which are such favourite garden flowers. He wanted to produce a number of new varieties, and to get these he began in this way. He got, from all parts of the world, nearly fifty kinds of lilies, all of which had in his eyes some particular merit which made them good, though not perfect, garden flowers. These lilies were crossed and intercrossed in the most elaborate way, a long series of experiments being performed.

The result was a large amount of hybrid seed. This seed was sown, and finally as many as a hundred thousand hybrid lily plants were produced. Two acres of ground were planted out with these lilies, and all were allowed to flower. The result of the crossing was such that among these hundred thousand plants almost every possible variety of lily 
was to be found. Some were purely fantastic, with no special beauty; others had beauties not present in any one of the original lilies, but produced by the process of hybridisation.

This was the first step, the crossing. The next step was, of course, the selection of the best kinds. The fields of lilies had to be gone over with painstaking care. All the useless or ugly plants were pulled up and burnt without mercy. Quite often among these hybrids would be found one which had some particular merit, perhaps colour or perfume, and at the same time some undesirable character, such as a stalk too weak to carry the flower head, an unsymmetrical flower, and so on. In these cases it was necessary to recross with another lily, in the hope of getting new hybrids which had all the merits and none of the disadvantages. This recrossing had, of course, again to be followed by fresh cultivation and selection.

In this way more than a million lily bulbs were grown, and the final result was that some two hundred and fifty thousand distinct lily hybrids were produced as the result of the experiments. Only some of these were, however, useful. These cases show us what the gardener can do by cultivation, crossing, and selection to improve plants.

But it is not sufficient to produce a new variety; it is necessary to produce it on such a 
scale that it can be supplied to many people. One great advantage of such plants as the lilies is that once a desirable kind has been produced, it may be increased by means of its bulbs, instead of

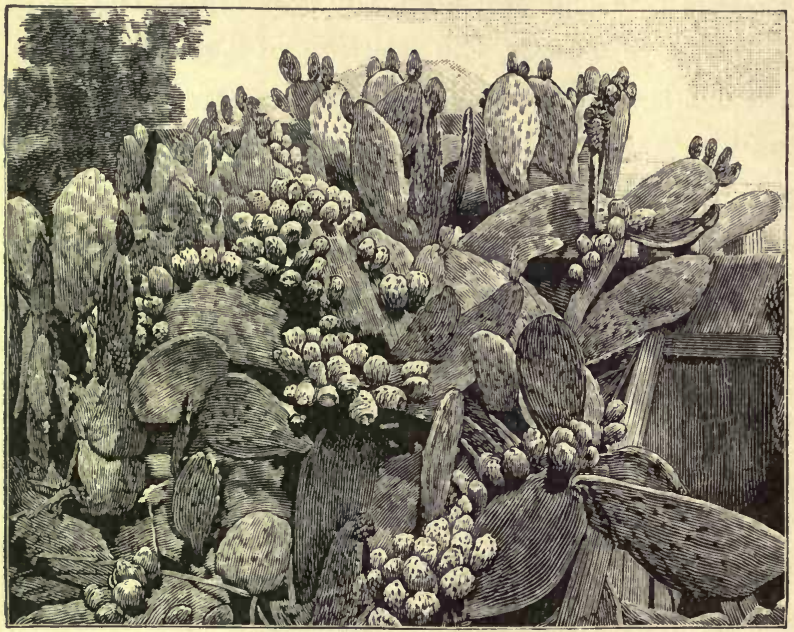

FIG. 39.-One of the improved prickly pears with large fruits produced by Mr. Burbank. The plant is four years old, eight feet high, and bears over 400 pounds of fruit. Half of one leaf put in the ground in April produced over sixty leaves by the middle of September.

only by seed. This is a great advantage, because improved plants which can only be reproduced by seed show a great tendency to " run back" to the original stock. On the other hand, when they can be reproduced by a part of the original stock, such as a bulb, a cutting, a tuber, as in the 
potato, they "keep true," that is, do not change in character.

Most of our cultivated plants, except where the seeds are the edible part, are reproduced by some part of the parent plant, or, as the botanists say, "vegetatively." This is a method which has many advantages. Take the potato, for example. It is possible, by the crossing and selection process which we have described, to make a new variety of potato, which will combine merits found hitherto in separate kinds. That is to say, it may be hardy like one parent, and very early or very prolific like the other. Now, if this potato had to be grown from seed each year, not only would the process be much slower than the present way, where a piece of potato is put into the ground, but also the seedlings would not be all alike. Some would have kept their hardiness, but lost the power of ripening early. Others would be ready early, but would be delicate, and so on.

This means that though man can make almost any kind of plant he likes, if he has patience enough, yet it is very difficult for him to give his "creations" the power of lasting, the stability which natural plants have. In Nature, plants are generally very like their parents, they are generally stable. By cultivation, and especially by crossing, man can easily destroy this stability. He can, as 
it were, make the plants rock to and fro instead of keeping steady. What he always wants to do is to stop them when they have moved just to the point that suits him, and that is the difficulty. When they have reached that point they either go on, or else they seem to want to come back to the point they started from. They seem to remember the peculiarities of their ancestors, and to feel a kind of homesickness to be back to the point they started from.

Perhaps this may seem a fanciful way of putting the matter, but, however we put it, it is of the greatest importance to us. Civilised man prospers and multiplies because, by working through long ages, he has succeeded in producing all sorts of wonderful plants, which feed and clothe him. But those plants, cultivated and improved by man for a few thousand years only, go back as wild plants into the inconceivably distant past. In their cells and fibres they have memories of the time before man was; let civilised man slacken his grip never so little, and they will slip back into their ancient ways. They will become poisonous, or unwholesome; their seeds will grow small, their fruits bitter, their roots will become tough and fibrous again, and so on.

When we read that man started to cultivate plants thousands of years ago, that he has been 
successful in improving them during long generations, we are apt to think that the work is practically done, that we need only enjoy what our fathers have done for us. But it is not so. Our

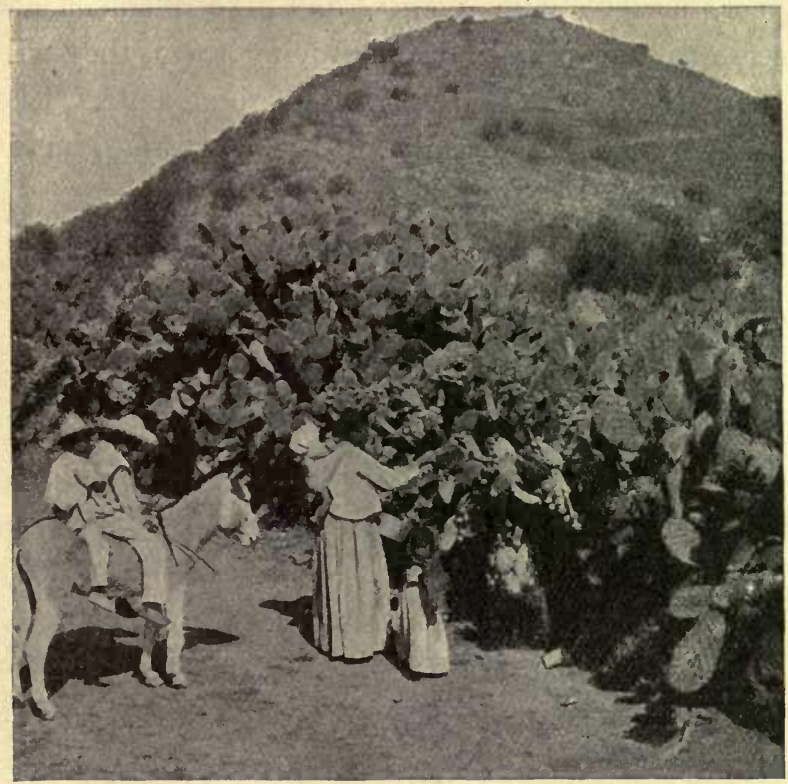

FIG. 40.-Gathering Wild Prickly Pear Fruit in Mexico, where the plant is native.

inheritance is like the magic gold in the fairy tales. If we do not use it aright it will turn into a mere handful of withered leaves, and leave us poorer than we were before we got it.

We know that Cinderella's beautiful coach was 
made out of a pumpkin, and changed back into a pumpkin as soon as the clock struck twelve. Well, our apples and pears, all our garden fruits and flowers and vegetables, indeed, were made out of poor, useless, wild plants, and the moment we cease to try to keep on improving them, they will begin to slip back into their original state. The change is not so sudden as in the fairy, tales, but it is just as real.

One other point about improving cultivated plants is important. We have just seen that in the case of plants produced from seed, there is always the risk that the seedlings will not have all the good qualities of their parents, a risk which does not exist when the plants are reproduced vegetatively. But plants which are always reproduced from seeds are at least frequently annuals, and they have the great advantage of quick growth. There are some grains which can be sown and harvested within a period of three months. In warm countries, if there is enough water, more than one crop of these plants can be raised in the year. The result of this is that improvements can be made rapidly.

On the other hand, when plants are not annuals, they very frequently take several years, sometimes many years, to come to flowering age, and in that case improvement by crossing must be 
a slow process. Mr. Burbank spent twenty-six years over his lily experiments - a very long time! The reason was that after he had crossed his lilies he had to wait till they flowered before he could see the result, and lilies grown from seed do not flower for some years. Once they got to flowering size he did not need to sow seed again, for he could use the little bulbs, but he had to wait a long time till they did flower.

All this simply means that when plauts are annuals and are multiplied by seed, they can be improved comparatively quickly, but the improve-

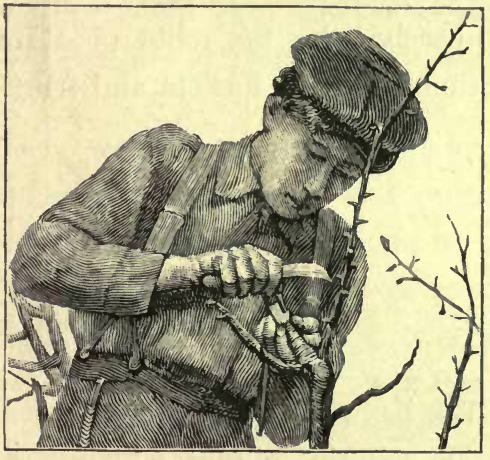

FIG. 41.- How Grafting is effected. ments are not always constant-the process of selection has to be kept up. When plants are reproduced vegetatively, and are perennials, it takes longer to improve them, but the improvements are more constant.

In the improvement of fruit trees, which often only grow very slowly to maturity, the process of grafting has played a great part. Grafting is certainly old, but it is now carried on on an 
extensive scale, and can be used to make the improvement of cultivated plants much more rapid.

Grafting means the fastening of a little branch of a valuable tree to a branch of a less valuable tree. If it is properly done, the graft, or scion, joins completely to the tree or stock, and grows as if it were part of it. It is usual to cut away all the branches of the stock, so that all the food absorbed by its roots goes into the graft, which then produces flowers and fruit.

\section{CHAPTER XV}

\section{THE STRUGGLE WITH DISEASE}

WE have seen that, ages and ages ago, man picked out certain plants which were worth cultivation, and began to grow these with special care. We saw next that this was done only at certain places on the surface of the earth, and that the people in other parts were for the most part content to borrow these plants, which in this way gradually spread over the earth. We saw also that this spreading process is now going on at perhaps a faster rate than ever it did before, with the result that the earth is year by year producing more food for man. 
Then we saw that, partly as a more or less unconscious result of cultivation, and partly by deliberate effort, man has been, and is, improving his plants, so that they become better fitted for new countries, so that they produce more and more abundantly. But this is not nearly all ; we have still to consider what is in some ways the most interesting point about the cultivated plants-the desperate struggle man has had to wage with plant diseases.

We have seen already what wonderful things he has done. He has toiled continuously to wrest her secrets from Nature, and, with every problem he has solved, he has become more skilful in bending her to his will. But it is not an easy task, and every now and then Nature takes her revenge on a big scale. Man brings the potato from America to Ireland, where wheat grows badly because of the damp climate. Here the potato grows abundantly, and becomes the staple diet of many of the people. Then Nature rebels, and sends a deadly disease; the potatoes are blackened and destroyed, and thousands of people are brought suddenly within sight of starvation.

For thousands of years man grows the vine superbly in the sunny parts of Europe, until the skill of the cultivators becomes a proverb, and the wine is world-famous. Then an insignificant little 
parasite is introduced by chance from America; it attacks the carefully. kept vineyards, and whole communities are half ruined.

These are only two cases out of many, two outstanding cases; but all through his history as a cultivator man has had to keep up this ceaseless struggle. It is a struggle in which he cannot stop to rest for an instant, a heroic struggle which has made many heroes. It is the green plants only which can bring from the sun's rays the energy necessary for life, and therefore man must grow green plants, or die. It is the starch and sugar which the green plants make which enable us to use our muscles. It is the green plants which form the coal which moves our machines.

In the long-run, it is the green plant which moves the whole world of living things, and therefore the battle of the green plant is our battle. The potato disease, the vine disease, the wheat blight are so many threats against our supremacy; we must conquer them or perish.

We have read how Adam in the Garden of Eden was given dominion over the beasts of the earth, " over the fish of the sea, and over the fowl of the air, and over the cattle, and over all the earth, and over every creeping thing that creepeth upon the earth"; but over the enemies of his cultivated plants he was not given dominion, that 
he has had to conquer slowly for himself-and the battle is not yet won. It is a battle compared with which the struggle with wild animals is as nothing. Saul may have slain his thousands, but David has slain his ten thousands.

But just because the struggle has been so fierce,
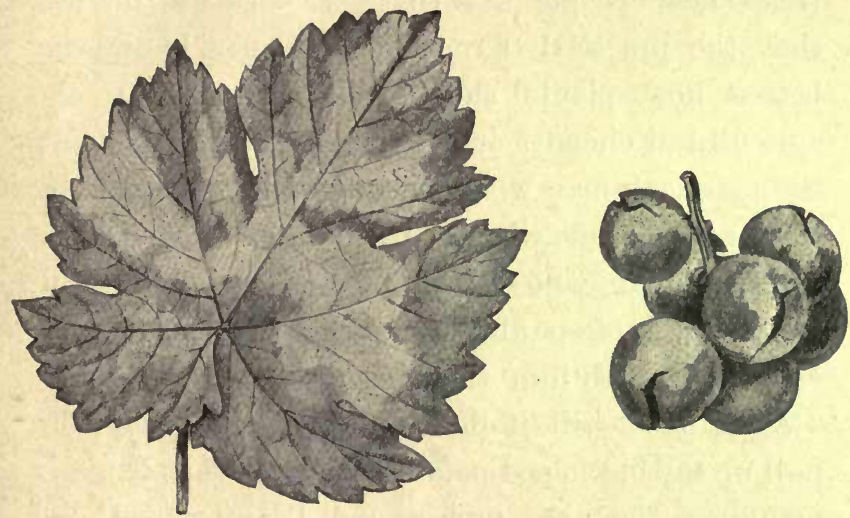

Fig. 42.-Mildew, a fungus which causes a destructive disease on the leaf and iruit of the vine.

it has taught man much. We have already read the little story of the great doctor who was prepared to begin again the moment he found that his past work had failed. In the struggle with plant disease, also, a remedy must be found, and therefore man must learn to reap success through failure. While men and women and children are dying of famine, others must be toiling to find a cure for 
the disease. Sympathy and charity are not sufficient; some members of the community must look beyond the needs of the moment to the future. This is one thing that the struggle with disease has taught.

One other point is as important. We sometimes hear people say that "science" is no use, that the practical farmer or gardener knows far better how plants should be grown than the agricultural chemist or botanist, and that it is only the practical man who has any right to speak on the subject. But when a terrible disease comes the practical man, who depends for his daily bread on his fields, is often almost crushed by the calamity. It is so near to him that he is reduced to despair. "What good will it do," he is inclined to say, "to pull up my blackened potatoes, and see what is really wrong? They are useless, and I am ruined, and that is the end of it all."

It is when this happens that the man of science can step in, and say, "Courage! it is not so bad as you think; we can help, we can perhaps prevent the same thing happening again; we can show you how to reduce the loss as much as possible." One of the uses of men of science is to prevent despair at critical moments. Very often they can do it just because, while the farmers have been growing potatoes and wheat and so on, they 
have been studying all sorts of little problems which at first sight do not seem to have any practical use at all, but which give them a knowledge of the conditions of life of plants which they could not get in any other way. They have, therefore, a starting-point from which they can proceed at once to study the new problem of the disease.

In order to understand just what the struggle with disease means, we shall take one case in a little detail, that of the mildew or blight of wheat.

This disease, to which the names of rust, mildew, and blight are all given, is very old, for it was known to the ancient Greeks, who had observed its ravages in their corn-fields. They thought the cause was the anger of the gods, and accepted it as one of the inevitable evils of life. Similarly, the Romans were quite familiar with the disease, which they thought was due to a particular goddess, to whom they offered sacrifices in order to avert her unwelcome attentions from their crops.

Pliny, some of whose curious opinions we have already considered, speaks a good deal of mildew, and what he says is very interesting. He begins by saying that it is due to "the inclemency of the weather," and goes on to say that "it attacks corn most frequently in localities which are exposed to dews, and in valleys which have not a thorough 
draught for the wind; windy or elevated spots, on the other hand, are totally exempt from it."

Now if this is not a very satisfactory explanation, it has at least an appearance of common-sense. But, and this is a curious point, he goes on to give other causes of mildew. The moon, he is disposed to think, has something to do with it, then there is something which falls from the Milky Way, which, he thinks, must be taken into consideration. Finally, there is the Dog-star belonging to " a constellation baneful in itself, and to appease which a young dog should first be sacrificed"! If the blight attacks the vines, then "three crabs" should be burnt among the trees on which the vines are trained.

Now it does not do for us to laugh too much at Pliny, for people believed very foolish things until long after his day, and the people of the future will probably think that we believe things just as foolish as the usefulness of sacrificing a "young dog." It is much better to try to find out exactly what the people in Pliny's time really thought. It is clear that by this time they had noticed that fields which were more or less constantly damp, either because they lay in hollows, or because they were surrounded by high walls, were more likely to be attacked by mildew than corn grown in exposed places, and also that damp weather increased mildew. 
Therefore, one party said that it was the damp which caused mildew, just as until lately people said that damp caused ague and marsh fever and malaria. We know now that these diseases are caused not by the damp, but by a minute organism which is carried from one person to another by mosquitoes, and that mildew is due to a fungus.

But in Pliny's time, in addition to the people who reasoned sufficiently to see that there was some connection between damp and mildew, there were other people who did not reason at all. They saw that mildew appeared in their crops in springtime, and they looked for the cause, not on the earth, but in the changes which were taking place in the sky at this season. To please these people Pliny gave instructions about the crabs and the young dog.

Let us take a long jump in time from Pliny and come down to the nineteenth century. In a little book published in 1846 (not so very long ago !) we read that blight and mildew have "three distinct and dissimilar causes." These are "cold and frosty winds, sultry and pestilential vapours, and the propagation of a parasitical fungus." The difference from Pliny's statements is not so great as it seems at first sight. This author adds a fungus as a cause, but he mentions that last. $\mathrm{He}$ does not tell us where the sultry and pestilential 
vapours come from, whereas Pliny thought they came from the Dog-star, but these are the chief differences between the two.

If, instead of taking a plant disease, we had taken such a disease as malaria we should have found almost the same thing; that is, that for many hundreds of years practically no progress had been made in determining the exact cause of the disease. It is a minute animal parasite which causes malaria, and it is a plant parasite which causes mildew in wheat, but in neither case could progress be made until other sciences had advanced. Before minute parasites can be studied we must have powerful microscopes, and it took a very long time to find out how these could be made.

Once again, a very great deal of the progress which has been made in recent years in finding out the causes of disease, has been due to the fact that men of science have a great number of dyes at their disposal to colour the minute animals and plants which cause disease. Even with very good microscopes it would not be possible to find out the details of the structure of these parasites, if it were not possible to "stain" them, as it is called, with certain dyes. Now most of these dyes are what are called " aniline dyes," which are obtained from coal-tar, and it was only in the middle of last century that these dyes were discovered. 
This is an interesting little fact because it helps to show us how all science, that is all knowledge, is linked together. We cannot hope to learn everything there is to know, we cannot even hope to be interested in all knowledge, but it is wise to learn to respect all knowledge, just because of this fact that it has always been found that one discovery fits into another like the pieces of a picture puzzle. It is a very far cry from mildew in wheat to the discovery of the aniline dyes, and yet without the aid of those dyes the botanists could never have found out all that they have found about the minute plants which produce mildew. Knowing also is the first

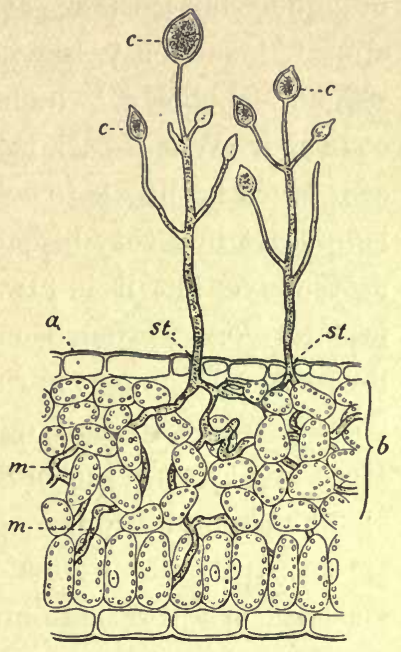

FIG. 43.-A Section of a Potato Leaf, attacked by the fungus which causes potato disease (much magnified). $a$ is the under surface of the leaf, which has pores (st.) through which the fungus enters. $b$ shows the loose tissue of the leaf through which the fungus threads $(m)$ spread. The spores $(c)$ project on stalks from the surface of the leaf, and are carried by the wind to other potato plants, so that the disease is very infectious. step towards curing, and it is a big step.

We have spoken of the ruin which such plant 
diseases as potato disease or the vine disease have brought, but these are diseases which have appeared suddenly, like the dreadful epidemics of plague or cholera which sometimes sweep over a country. Wheat-rust has been with man probably ever since he began to cultivate wheat. Sometimes it appears in a very bad form, and is then especially destructive, but it is always present to a greater or less degree. Perhaps some one then may ask, Does it really do much harm? Is it worth all the botanists' toil to find out the cause and the cure? Here are two sets of numbers which may help to answer this question.

In Australia a great deal of wheat is grown. In that country there are now nearly four million people. It is estimated that there the annual yearly money loss from wheat-rust is between two and three million pounds. That is, every year, every man, woman, and child in Australia, supposing the loss to be equally divided, would lose between ten and fifteen shillings from wheat-rust alone. In Prussia in 1891, which was a very bad year for rust, it was officially estimated that the loss to the community from the disease was twenty million pounds. We can see from these figures that it is very well worth while to try and find a cure for rust. Have we not all cause to be grateful to the people who have toiled to explain the why and the wherefore 
of those insignificant black or rust-coloured stripes which occur on the leaves of corn and other grasses?

We must remember also to include in our gratitude not only the individual people who have worked at this particular subject, but all the innumerable people who, quite often without intending it, have made the work of the others possible. The opticians who worked at improving microscopes, the chemists who made the dyes, we have already mentioned, but these are only two sets of people; it took a great number of other workers before the exact cause of rust in wheat could be explained.

Even yet there is still a great deal to be done, for it is not possible to prescribe a cure, though it is possible to suggest ways of diminishing the risk of infection. But it is clear, is it not, that knowledge does not come merely with the lapse of time? We haye seen that for 1800 years after Pliny not much progress was made. Progress comes when in a community there are a number of men, with different types of mind, who are willing to devote themselves to the search for knowledge. Each may only succeed in doing very little, but the next generation can stand on the platform they have built, and so rise to heights they never dreamt of. 


\section{CHAPTER XVI}

THE STORY OF RUST IN WHEAT

How can we recognise the disease variously known as blight, rust, and mildew? Suppose we examine in summer-time a field of wheat, oats, or rye, or even a meadow full of grass. Especially if the summer has been a damp one, we shall find quite likely that some of the plants have long, rustybrown streaks on the stems and leaves. These streaks are like rust not only in colour but also in the fact that we can rub off a red powder. Later in the season we may find, instead of these rusty streaks, black or very dark streaks, which blacken the fingers, just as the other kind reddened them. The first stage is the rust stage and the second the mildew stage of wheat disease.

(See the diagrams on p. 198).

The next point to be considered is, what harm does the rust or mildew do to the wheat plant? This is very readily explained. The black or brown streaks on the leaves mean that the substance of the leaf is largely destroyed. Now it is by the leaves that the plant makes the starch which so largely fills the grain. The presence of the streaks 
therefore means that the plant has less power of starch-making, and therefore the grains are small and light.

That the cause of these streaks was a fungus was known some centuries ago, and as soon as the development of the microscope permitted, it was recognised that the powder on the infected plants was what the older botanists called the "seeds" of the fungus, and what the modern ones call spores. That by these spores fresh plants could be infected was an obvious conclusion, which was drawn comparatively early. For instance, Sir Joseph Banks, writing in 1805 for English farmers, gives the following account of what was then known as the fungus. He does not, we must remember, profess to put forward anything new about the fungus, but simply to tell farmers what the botanists thought at this time.

He begins by explaining that on the surface of the leaves and stems of the grasses there are minute pores. He regards these pores as a means of taking in water, for he says: "A plant cannot when thirsty go to the brook and drink, but it can open innumerable orifices for the reception of every degree of moisture, which either falls in the shape of rain and dew, or is separated from the mass of water always held in solution by the atmosphere; it seldom happens in the driest season that the night 
does not afford some refreshment of this kind, to restore the moisture that has been exhausted by the heats of the previous day."

We know now that Sir Joseph was wrong in thinking that the use of the pores on the leaves of plants is to allow them to take in water. It is the roots which take in water, and the leaf-pores allow the surplus to escape, besides having other uses. He was, however, perfectly right in believing that it was through these pores that the fungus found an entrance. Here is his account of the process, which is rather interesting :

"By these pores, which exist also on the leaves and glumes [that is, the scales on the ears], it is presumed that the seeds of the fungus gain admission, and at the bottom of the hollows to which they lead, they germinate and push their minute roots, no doubt (though these have not yet been traced), into the cellular tissue beyond the bark, where they draw their nourishment, by intercepting the sap that was intended by nature for the nutriment of the grain ; the corn, of course, becomes shrivelled in proportion as the fungi are more or less numerous on the plant; and as the kernel only is abstracted from the grain, while the cortical part remains undiminished, the proportion of flour to bran in blighted corn is always reduced in the same degree as the corn is made light. Some corn of this 
year's crop will not yield a stone of flour from a sack of wheat; and it is not impossible that in some cases the corn has been so completely robbed of its flour by the fungus, that if the proprietor should choose to incur the expense of thrashing and grinding it, bran would be the produce, with scarce an atom of flour for each grain."

Sir Joseph Banks goes on to say: "Though diligent inquiry was made during the last autumn, no information of importance relative to the origin or the progress of the blight could be obtained: this is not to be wondered at; for as no one of the persons applied to had any knowledge of the real cause of the malady, none of them could direct their curiosity in a proper channel."

He then proceeds to explain that the corn seems to become infected in spring or early summer, and that the streaks are first orange, and later, as the straw ripens, become chocolate-brown. He knew also that what he calls the "seeds" of the fungus are produced in great numbers, and are very light, so that they could be carried easily by the wind, but he was puzzled as to what became of the fungus during the rest of the year, and how it reached the wheat in late spring.

But there was at least one direction in which it was hopeful to look for an explanation. During the whole of the preceding century, that is the 
eighteenth, the farmers had been getting more and more convinced, that, absurd as the suggestion may seem at first sight, the common barberry bush had something to do with blight. "It has long been admitted by farmers," Banks says, "though scarcely credited by botanists, that wheat in the neighbourhood of a barberry bush seldom escapes the blight. The village of Rollesby in Norfolk, where barberries abound and wheat seldom succeeds, is called by the opprobrious appellation of Mildew Rollesby."

Another example which he might have given was that some fifty years earlier, in 1755 , the farmers of Massachusetts were so convinced of the connection between barberry and rust that they succeeded in getting a law passed to order the rooting up of the barberry bushes, because of their bad effect in occasioning the "Blasting of Wheat and other English Grain."

The difficulty was, however, that when asked why they thought that barberries produced mildew, the farmers could only reply feebly that barberry pollen was yellow, and rust was yellow to begin with, and perhaps it was the yellow barberry pollen that fell on the wheat and made the rust! It was much the same story as that of Mohammed and the date-palms over again. Nobody could give Mohammed any intelligible reason why branches of wild dates should be hung over the date trees in 
the gardens, and the farmers could give no intelligible reason why barberry bushes were bad for corn, but the Arabs and the farmers were right and Mohammed and the botanists wrong none the less.

Sir Joseph Banks felt that if the farmers were right about the barberries there must be some reason, and therefore he offers one. "It is," he says, "notorious to all botanical observers that the leaves of the barberry are very subject to the attack of a yellow parasitic fungus, larger, but otherwise much resembling the rust in corn.

"Is it not more than possible that the parasitic fungus of the barberry and that of wheat are one and the same species, and that the seed transferred from the barberry to the corn is one cause of the disease?"

We notice that Sir Joseph Banks only suggests this as one cause of the disease, his idea evidently being that the fungus could grow indiscriminately on barberry and wheat. There is added to his paper as an appendix a letter from Mr. T. A. Knight, who was a distinguished agriculturist living at this time. In this letter Mr. Knight details some experiments which he had performed to try to find out whether the fungus found on barberry had anything to do with wheat blight. He succeeded in showing that wheat sown round an infected barberry bush all became infected with blight by 
the beginning of July, up to which time the plants remained free from disease.

He found also that wheat plants at a distance from the barberry bush remained permanently free from disease, showing that the weather in itself did not affect the question of blight or no blight. He also showed that wheat plants free of blight could be infected artificially by bringing branches of barberry with fungus on them close to the wheat plants. But his experiments were performed in what a botanist would call rather a haphazard fashion, and therefore they left him in some uncertainty as to whether damp had not at least as much to do with the disease as the fungus on barberry.

A few years later a Danish schoolmaster, called Schoeler, carried out some further experiments which made the connection between the barberry fungus and the blight in wheat more certain. At the same time, however, it was not clear exactly what was the exact relation between the two; quite a number of people therefore persisted in saying that the idea that barberry bushes in the hedges were bad for wheat-fields was merely an idle tale.

As in so many other cases it was not possible to solve the problem completely until some other questions, apparently not nearly related, had also been solved. It was not sufficient to study rust in 
wheat alone; much had to be learnt about fungi in general, before this particular fungus could be understood.

We find, therefore, that the next stage in the study of rust was one which did not seem to have anything at all to do with that particular disease. About the middle of the nineteenth century a French botanist called Tulasne began to study fungi carefully, and he soon discovered a curious fact. This was that quite a number of fungi occur in different forms and on different plants.

Let us think what this means. A primrose growing in a wood and a primrose in a garden are both primroses, even if the garden one is larger or finer, or in some way slightly different from the wild one. But there are many fungi which can grow in different situations, or on different plants, and then they are so different in appearance that no one would believe, without proof, that they had any connection with one another. Tulasne showed that there were a great number of cases of this kind. Now it is very easy to show that the fungus on the barberry is very different from the rust of wheat, but Tulasne's work showed that this difference did not make it impossible that the two were nearly related.

The next step was actually to follow the history of the rust throughout the year, to see exactly 
what position the fungus on the barberry occupied. This was finally done in 1865 by a German botanist called de Bary, who grew the little spores both on wheat and on barberry, and followed out completely what the botanists call their life-history.

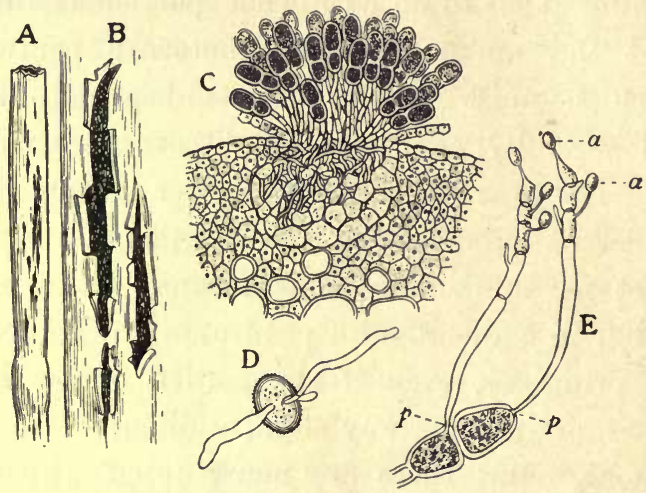

FIG. 44.-Diagrams showing Rust in Wheat. $A$ and $B$, stems of wheat showing the streaks of rust. $C$, a part of the stem magnified showing the spores protruding. $D$, a summer spore, which infects a new wheat plant. $E$, a winter spore, which infects barberry in spring.

De Bary showed that in the late spring the spores from the barberry fungus are carried by the slightest puff of air to the wheat in the fields. If a spore falls on a wheat or grass stem, it puts out a little tube, and creeps along the surface of the stem until it reaches one of the pores. By this pore the tube enters the stem and then grows fast, spreading out in all directions inside the stem. After a time the 
fungus plant is ready to form spores anew. These spores burst through the skin of the stem or leaf, and are carried by the wind to other wheat plants, which are thus infected in their turn.

This goes on all through the summer weather, but autumn comes on, and the wheat plants begin to turn yellow. This is a warning to the fungus that it is time to prepare for winter. It stops producing the rust-coloured summer spores, and instead produces dark-coloured resting spores (the mildew), which have a thick coat to resist the winter cold.

These dark-coloured spores remain through the winter in what is called a resting condition. When spring comes they sprout on the ground and make new spores. But where can these go? The wheat is very little above the ground; it cannot yet feed a greedy fungus. But in the hedgerows the barberry bushes are putting out their fresh leaves. If the spores are by chance carried to these leaves, they again sprout and form pretty little yellow cups on the under side of the leaf, each cup being full of spores. These spores are carried later by the wind to the wheat, and so the whole story begins over again.

This, then, is the history of rust, as it was finally worked out by de Bary. It might be said that it shows that the way to stop rust is to root 
up the barberry plants. Unfortunately, however, other botanists have shown that, though the fungus generally needs to spend part of the year on the barberry, yet in some countries, as in Australia, it seems able to do without the barberry. Even in parts of England - at least sometimes -it can do without that plant, perhaps using some other plant instead. But if we do not know yet how rust may be prevented altogether, we at least know enough now to see in what direction help is to be sought.

\section{CHAPTER XVII}

PLANT FOOD AND THE UTILISATION OF THE SOIL

OF all the improvements which man's toil and patience have produced in the growing of plants, perhaps in some ways the most important is the improvement of methods, especially of methods of treating the soil. It seems clear at least that, in the immediate future, the greatest progress in connection with agriculture will be made along the lines of the proper utilisation of the soil-in learning how to make it fertile and how to keep it so.

The whole story of the way in which man has 
learned to use the soil aright is too long to tell here. All that we can do is to pick out a few famous names, and show with what steps in progress these names are associated. Of special importance are the questions associat with the problem of where plants get the nitrogen they require to make their proteids (see p. 117), and we shall restrict ourselves in this chapter to that problem.

We will begin with the work of Baron Liebig. Liebig was a great German chemist who was born in 1803 and died in 1873. He made many great discoveries; he invented the first meat extract; he compounded a food for infants; he did many other things for his country and for the world. All that we need stop to learn about him here, however, is that he was the first to state a consistent theory about the food of plants in relation to farming. This theory was called Liebig's "Mineral Theory." Theory is not perhaps the best word to apply to it, but it was the word which was used.

It was not a theory in the sense of being spun from his imagination without any relation to actual fact. A scientific theory is an attempt to explain results obtained by observation and experiment. Liebig first did something. What he did was to burn many plants - to burn them under special conditions and with great care. He burnt plants from many different localities, and 
carefully examined the results of the burning, his examination being of the kind which a chemist calls an analysis. What he found in the first place was that the results of the burning were, roughly speaking, always the same. Whether the plants grew " on the most diversified soils, in the most varied climates, whether cultivated on plains or on high mountains," the same effects were produced when they were burned.

What was the effect of the burning? In the first instance he found that the burning plant gave off a colourless gas, which stifles animals; this gas we call carbonic acid gas. Secondly he found that it gave off small quantities of a gas called ammoniathe gas which brings the tears to our eyes when we take a big sniff of a bottle of smelling-salts.

When the plant had quite burnt away, Liebig found that there was left behind a little mass of greyish ash, like that which is left when wood burns away. In this ash he found what the chemist calls salts,- salts of potash, lime, magnesia, and so on. Liebig said, therefore :-All plants contain carbonic acid gas, ammonia, and salts. He knew, however, that ammonia does not occur in the living plant. It is the proteid of the living plant which makes ammonia when the plant is burnt.

He knew also that the carbonic acid gas produced by plants when they are burnt is got from the air; 
it does not need to be supplied in manure. He believed, further, that plants could also take ammonia from the air, and use it to build up proteid.

The practical conclusions which Liebig drew from his experiments, then, were that farmers need not trouble about giving their plants nitrogenous manure. The air, he said, contains plenty of nitrogen, just as it contains plenty of carbonic acid gas. Plants can get as much of these substances as they want. They cannot get salts from the air - these must be given in manure, but nitrogen need not be given.

These statements of Liebig gave rise to fierce discussion and to not a little quarrelling. Farmers had always been in the habit of giving their plants some form of nitrogenous manure, and they said that they were quite certain that wheat, for instance, would not grow without such manure. Liebig, on the other hand, said that, as there was plenty of nitrogen in the air, it was a pure waste of money to give nitrogenous manures to the plants. We know now that the farmers were right, at least for most plants, and that Liebig was wrong; but nevertheless he did a great deal for scientific agriculture, though he happened to be partly wrong on the question whether plants took their nitrogen from the air or from the soil.

One step of great importance which he took was 
to show farmers that when natural manure could not be got, then mineral substances could, to at least a large extent, be used in its place. $\mathrm{He}$ showed this practically by an experiment at which the farmers laughed a little, but which was nevertheless of great importance as an experiment.

He bought a little piece of almost barren ground, and by treating it with mineral manures, together with some other substance, he succeeded in getting from this barren land as good crops as his neighbours got from their fertile fields. The experiment was costly, for he put into his land, in the form of mineral manure, more than he got out in crops, but still it was very important to show that soil could be made fertile by adding the chemical substances which were naturally lacking in it.

The fate of this plot is rather interesting. "In the year 1849," says Liebig, " my former gardener, Kappes, purchased the land from me; and this industrious man, who has not the means to buy manure, farms with profit the little property, now in good heart. He is able, with the help of a small coffee and beer trade in the summer months, to support himself and his family on it; he keeps two cows, raises annually several oxen, and has gained what has enabled him to increase the farm buildings, - and all this without ammonia or humus -by means of mineral manure alone." 
What Liebig did for Kappes, he did really for the world; for our bread and meat to-day would be much dearer than they are were it not that Liebig had taught the farmers the value of mineral manures.

Much about the same time that Liebig was working at this subject, a French agricultural chemist, called Boussingault, was also interesting himself in the chemistry of plants. In his book on Rural Economy he speaks of the difficult subject of the source of plant nitrogen, and of a series of experiments he made in connection with it.

Let us quote a few words from this book, in connection with these experiments:

"I had necessarily," he says, "to follow a method of inquiry different from any which had yet been taken; I had no chance of arriving at more definite results than those which had been already come to, had I chosen the old line of investigation. I therefore called in the aid of elementary analysis, with a view of comparing the composition of the seed with the composition of the harvest produced from it, at the sole cost of water and the air. By proceeding in this way I believed that the problem was capable of solution; without flattering myself that I have completely resolved it, I conceive that something has been done in the right direction. The subject is one of the most delicate imaginable, and he who enters it requires indulgence." 
What did Boussingault actually do? His object was to grow plants from seed, giving them nothing but water and air, and then find out if they contained more or less nitrogen than was in the original seed. If there was more in the little plant than in the seed from which it grew, and the plant was given no nitrogenous manure, then it must have taken this nitrogen from the air. In other words, Boussingault wanted to answer the question:-Can a green plant take nitrogen from the air?

He made in the first place a series of very careful experiments, which seemed to show that clover and peas can take nitrogen from the air while wheat and oats cannot do this. He was not, however, satisfied with these results, for he could discover no reason why peas and clover should differ so markedly from wheat and oats. He, therefore, returned to his experiments again and again, always endeavouring to make the conditions more precise. For more than twenty years he toiled over the question, and his final conclusion was that plants cannot take free nitrogen from the air. That is, he answered his own question in the negative, believing that he had been misled in his first experiments with clover and peas.

A great number of other observers worked at the same question, and with very varying results, some 
asserting that plants could take up nitrogen from the air, and the majority that they could not. Among the most important of the negative results were those of the experiments carried out by Sir John Lawes and Sir Joseph Gilbert.

These experiments were carried out at Rothamsted, near St. Albans in Hertfordshire, a name which should be known to every Énglishman, for there have been carried out at this place experiments the value of which for English agriculture and for the world can scarcely be over-estimated.

The Rothamsted experiments, carried out very carefully for a long period of time, showed that there is no evidence that the members of the Grass family have the power of taking free nitrogen from the air; nitrogen must be given to their roots in a combined form before it is any use to them. As regards the plants of the Pea family, the experiments, like the later experiments of Boussingault, showed no gain of nitrogen, but - and this is an important point-Lawes and Gilbert state definitely that it did not seem to them that the plants of this family grew satisfactorily during their experiments, and they were not satisfied that, under better conditions, these plants might not have shown that they could take up free nitrogen.

This important paper was published in 1860 , and it was generally supposed to have settled the 
question-it did settle it for nearly thirty years. But even this paper ends with a doubt, for the authors say that if no plant can take free nitrogen from the air, then it is not clear how the supply of combined nitrogen in the soil is kept up.

The air is full of free nitrogen, but if it is no use to plants then they must depend entirely upon the combined nitrogen of the soil. But every year our rivers are carrying out to the sea a large amount of combined nitrogen, which has been taken from the land and is swept out to the sea where it is useless to man. Is the soil then every day growing poorer? Will there come a day when there is no longer enough manure to grow the crops necessary to keep man alive? Will the earth grow poorer and poorer, and the crops smaller and smaller till we come nearer and nearer starvation? This was the problem that was left, or at least the practical side of it.

Then there was also the theoretical side; this curious mystery of pea and elover, which seemed sometimes able to fix free nitrogen, but always lost their power of doing so when they were tested under the rigid conditions of ${ }^{\circ}$ an experiment. When would the key to this mystery be found?

Although for many years it was generally believed that no fixation of free nitrogen occurred, yet experiments went on, many different people 
being interested in the subject, and following it along many different lines. One point of great importance came out of researches which had only an indirect reference to the nitrogen problem. This was the gradual development of our knowledge of

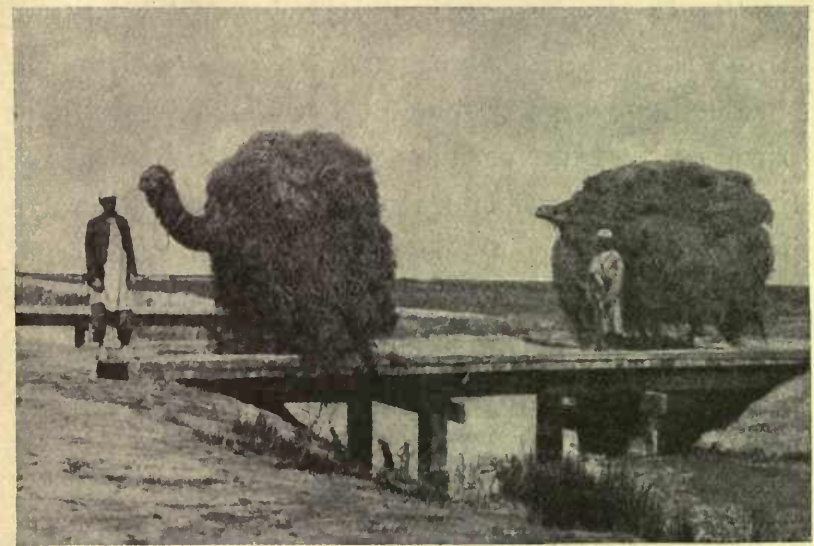

Fig. 45. - Camels carrying Green Berseem, or Egyptian Clover, to market in Egypt. The clover is grown both as a food for animals and because it improves the soil.

the minute organisms called bacteria, which were shown to be the causes of many processes previously regarded as mysterious.

In 1876 the great French chemist Berthelot pointed out the possibility that bacteria with the power of fixing free nitrogen exist in normal soil. This, as he showed, might explain some of the differences between Boussingault's various experi- 
ments, for in some of these the sand in which the plants were grown was so treated that it could not be supposed to contain living bacteria. In the Rothamsted experiments also, the sand was carefully sterilised, that is, any bacteria present were killed before the experiment began.

Berthelot made some other suggestions and performed some experiments which helped to throw light upon the problem, though they did not solve it. He died, it may be mentioned, in 1907, and was one of the last of the great scientific men of the middle of the nineteenth century. Many tales might be told of him, but for these we have no space now, no space even to tell of the dignity with which at the last he laid down his finished task, and entered into rest. That is, however, a story which is well worth reading.

Going back to the nitrogen problem, we find that when Berthelot had made the suggestion about the bacteria the answer was nearly found, though it was ten more years before it was finally given.

In 1886, a German man of science named Hellriegel read at a meeting in Berlin a paper on a long series of experiments which he had performed. These experiments gave the following results. Clover, peas, beans, and other plants of the Pea family have usually on the roots little nodules 
which contain bacteria. These bacteria possess the power of fixing free nitrogen. Plants of the Grass family, turnips, and other food-plants not belonging to the Pea farnily, do not possess these nodules, and cannot fix free nitrogen. Clover or peas grown from seed only develop the nodules if the bacteria are living in the soil. This is the reason why Boussingault's experi ments and the Rothamsted experiments were so contradictory, for sometimes nodules were present and sometimes they were not. When they were present the plant could fix free nitrogen, when they were not it could not.

A number of other investigations were made which confirmed these

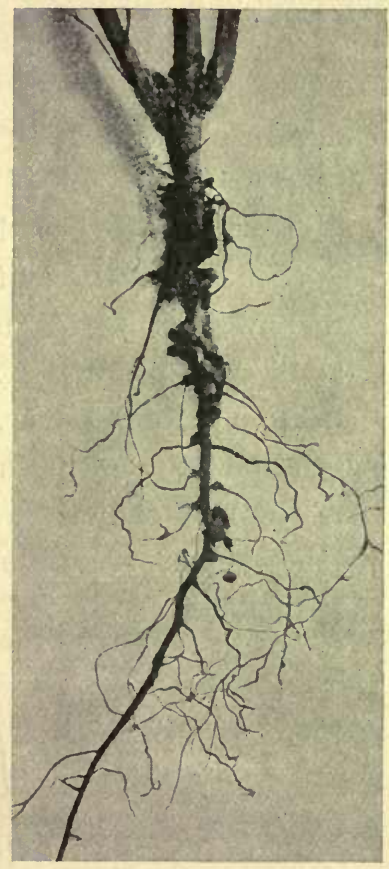

FIG. 46. - Nodules on the Roots of Clover. statements, and we know now the reason why clover enriches soils. It is not the clover which enriches the soil, but the insignificant bacteria on its roots, which can take free nitrogen from the air 
and fix it in the soil in a form in which it can be used by other plants.

We know now, therefore, that while most green plants must take their nitrogen from the soil in the form of a salt called a nitrate, plants like clover and peas live in partnership with bacteria which can take nitrogen from the air, and hand it on to the green plant, and also leave part of it stored in the soil for the plants of another season.

Later investigations have taught us many new facts about the soil and the use of manures. It is clear now that we do not need to fear that the soil will grow poorer, for not only are there bacteria ready to enrich it for us, but the chemist also has shown how the nitrogen of the air may be fixed, with the help of lime, in a form which can be used by the higher plants, an artificial manure being thus produced.

\section{CHAPTER XVIII}

\section{THE GAINS THAT KNOWLEDGE HAS BROUGHT}

BEFORE proceeding to sum up generally the gains that the slowly acquired knowledge of the ages has brought to mankind-gains in wealth, gains in security, gains in power to turn the stubborn 
earth to his will, let us look for one moment at one other picture of human skill.

If we cross the Channel to France, and travel eastwards till we reach Paris, we find that, like London, like all large cities, Paris is surrounded by a ring of market-gardens, a circle of highly cultivated land, the object of which is to supply some part, at least, of the needs of the great city. But just as the English farmer is the most skilful in the world, and gets more from his wheat land than any other, so the market-gardeners round Paris are the most skilful in the world, and can do marvels which no others can imitate with their tiny patches.

The English farmer has won the favour of the goddess of fertility, who pours her golden grain into his lap in unstinted showers. It is a more stubborn goddess that the French gardeners woo. Proserpine, the goddess of spring flowers, of sprouting corn, and of unfolding leaves, comes tardily everywhere, for the time seems long till she appears. But while others must wait her coming; be it soon or late, the gardeners of Paris can bring her at their will. So powerful a charm have they, that, in bleakest January, she will smile beneath their frames. Nay more, while elsewhere the spring, though it come with lagging feet, must nevertheless fly at the approach of summer, here these 
skilful tillers of the ground can make her linger at their will.

What exactly does all this mean? Some of us have perhaps been in Paris. If not, we have perhaps heard others tell of the flowers which are to be always seen in the streets of that city. On certain special days, whatever the season, these flowers seem to be found everywhere. Flowers in bunches, flowers growing in pots, flowers overflowing the pavements - there is no end to them. These days when the flowers are so plentiful are nearly always Saints' days, and the reason for their abundance then is rather curious.

In France, it is customary to give the children the names of some one or other of the great Saints, and then very often, instead of the birthday of the boy or girl, it is the name-day, the Saint's day, which is kept as a family festival. The French love flowers, and in Paris there are many Jeans and Jeannes, many Louis and Catherines, many Jacques and Maries. Therefore, on every one of the Saints' days, there will be many people who want to buy a pot or a bunch of sweet-smelling flowers for some relative or other. Therefore, again, the gardeners make great preparations for these days.

A Paris gardener is reckoned really clever when he can make hundreds of pots of daisies or roses or 
lily of the valley, or some other beautiful flower, show a lovely mass of bloom just on the eve of a great Saint's day. If the season be an early one he must keep his plants back; if it be a late one he must force them on. In any case he must know how to arrange things so that the flowers are neither a day too late nor a day too early, but just at their best the morning they are wanted.

It would take too long to tell even some of the ways in which the gardener makes himself almost independent of the seasons. A few words we must say, however. of his methods. By centuries of striving the French gardener has reached a level which his forefathers never even dreamt of.

He does not, of course, confine himself to flowers. A great many of the early delicacies of the Paris and also of the London markets are produced in his gardens. Early salads, early asparagus, early peas, early strawberries, almost all the fruits and vegetables that come out of their season, and are therefore valuable, are grown round Paris.

The two essentials of the French methods are, first, a very rich soil, and second, protection from the weather, by means of glass frames or bell glasses. The richness of the soil is produced by using enormous amounts of manure, and so clever are the 


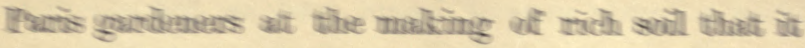

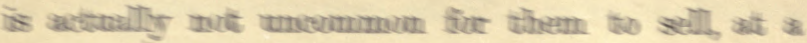
Irigh geries, a linger of soull firom the tomp of theeir

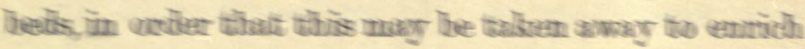
sume abler grithen.

The manume whichl is putt intoo the soill makes the suill wemem, and so lielyss to fruce on the plants:

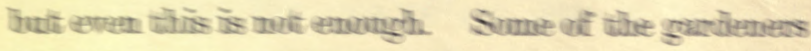

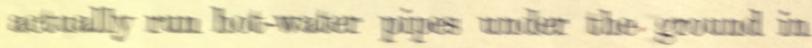
ordier to warm itt and forme their glemiss to grow

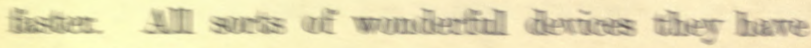

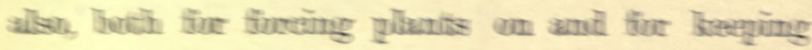
them loukt, $\mathrm{SD}$ that thegr ean be pout on the

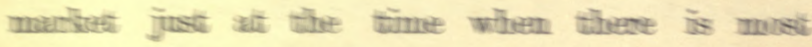

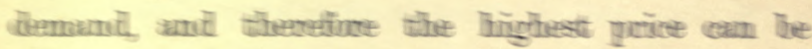

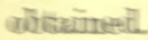

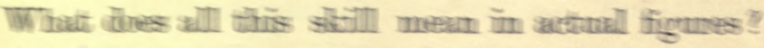
Whill, in many parts of Englamid, and in many

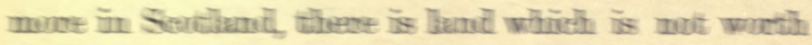

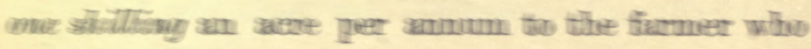
owns it ore menliss ith. Inspitte of the skill of Engthish

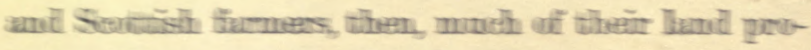

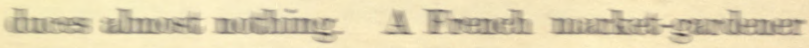

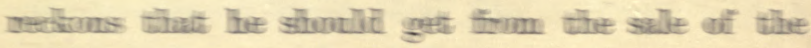

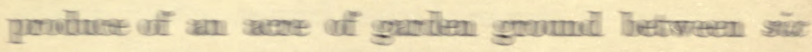

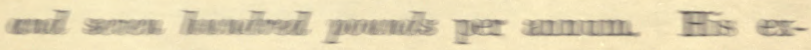

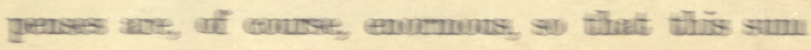

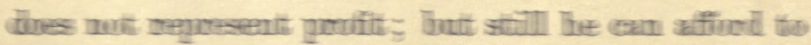




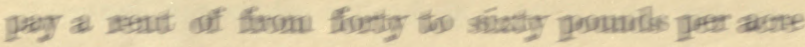

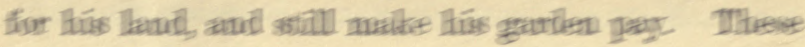
figruese help to maike ms madenstand the reilue of

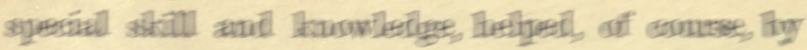
nearness tor a lavge matidet.

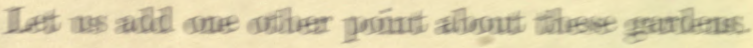
It seems liltally that they will anot jonve 500 gnofitallile in the finture as in the past. Wiyg? It is

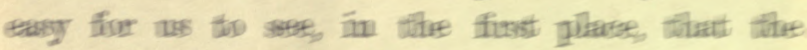

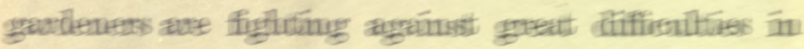
the wery of elfimatbe. The leat wineth the smo will not gine they must supuits ity manure cor emeen ing

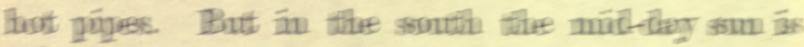
altreacy lingth and poweerill whille he is low and weerle at Paris.

Therefione the perpile in the south, sineen encen

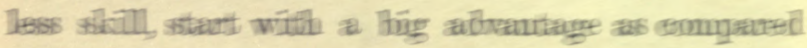

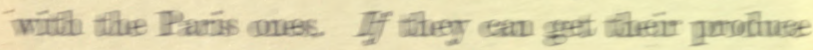

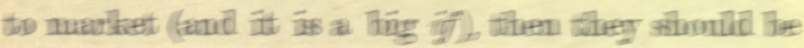

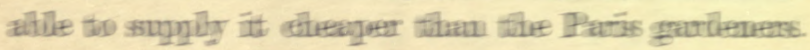
In Algeria att thite present time the growuing of early

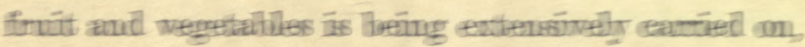
and more and more the methodes of purting the proctuere quielthy on the Paris martiet are lowing ingrowed.

Anotiher poinit is thatt the market grardener de-

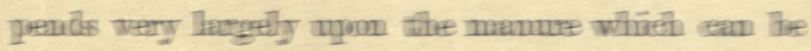
easilly ahtanined in a large enthy where many linorses 
are kept. He depends upon it not only to enrich his soil, but also to heat it by the process of fermentation. More and more in Paris, however, the horse is being replaced by the motor-car, and therefore

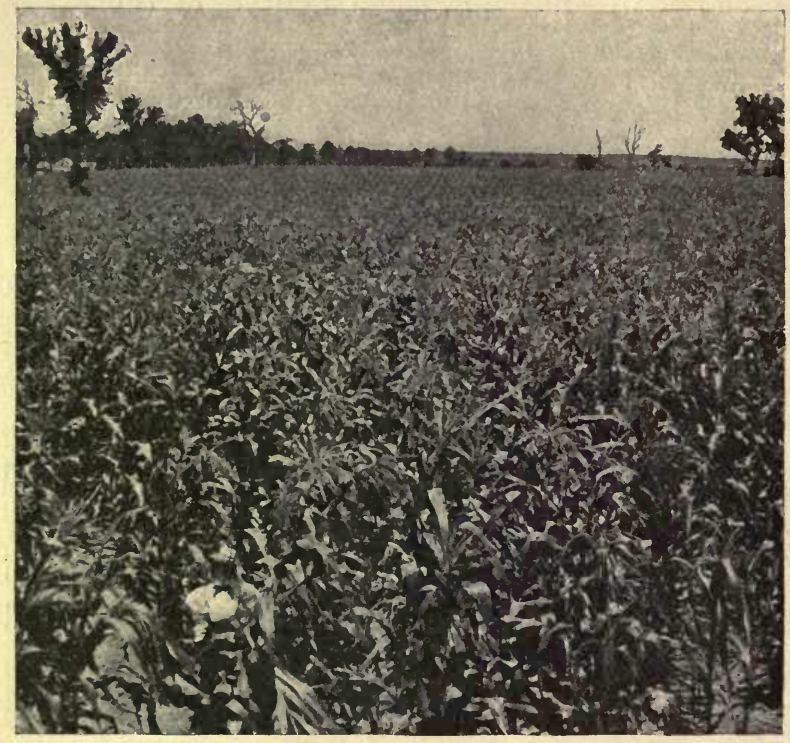

FIG. 47. - A Field of Maize in Eastern Kansas.

horse-manure is becoming dearer. Here is another difficulty in the way of the gardener.

On the whole it seems likely that his work will get more difficult as time goes on, and that his methods will perhaps have to be changed with changing times. From what we know of the 
history of these gardeners in the past, however, we may be sure at least that they will learn to adapt their methods to changing conditions; that they will not lose their control over Mother Earth.

Taking the market-gardens of Paris as a sign and a symbol of the control over Nature that knowledge has brought, let us go back and review briefly the path that has led man so far.

We began, it will be remembered, with some examples of people who made no attempt to till the ground at all, who were content with what it produced naturally. Then we caine to the people who cultivated a little, but who did not know how to use the ground aright. These people seemed to be struck with the curse of Cain. We remember how it was said to him: "When thou tillest the ground it shall not henceforth yield unto thee her strength; a fugitive and a vagabond shalt thou be in the earth."

We know enough now to see that this must always be so, that unless man can succeed in making the earth yield to him of her strength, he must always be a fugitive and a vagabond, wandering from place to place as he exhausts the soil, incapable of making peaceful and permanent settlements.

As contrasted with these primitive conditions, we saw that the nations which we call civilised 
have learnt step by step all the great lessons. First, they found out which plants were best worth cultivating, and this - the first and greatest lesson - was learnt in three special parts of the earth's surface only. In order that these plants might be useful to all the earth, then, they had to spread out in all directions from the places where they originated, so that West might learn from East, and West again might give back a hundredfold for all that she received.

As they spread, and were cultivated over larger and larger areas, the food-plants, we saw, were altered and improved, fitted for new countries and new conditions. We saw that at first the process of improvement was slow and almost unconscious, but gradually as knowledge increased it became quicker and more certain, until now the gardener can mould his plants almost at his will.

But, as man's skill increased, so also his enemies seemed to multiply. No sooner did the earth begin to bring forth abundantly than the struggle with disease and with destructive insects became fiercer, and the skill which had produced new plants, and made them more productive, had to be turned to the ways of protecting these plants against caterpillar and fungus, against beetle and fly. 
More than this, as soon as man had learnt to till the ground, he had to learn the deeper lesson of not only making it yield of its strength, but also of making sure that there was a reserve of

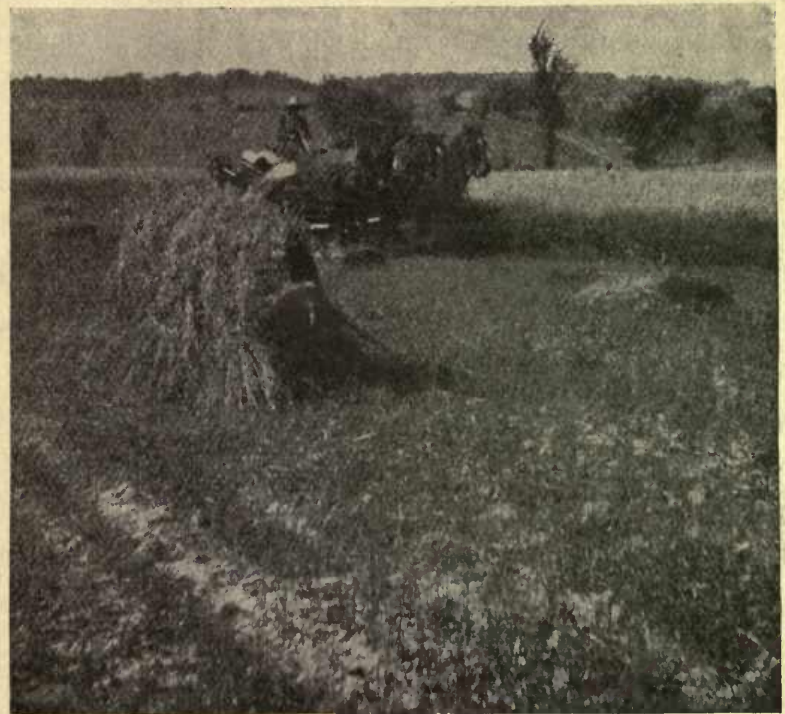

FrG. 48.-Cutting and binding Oats in Ontario.

strength for the future. He has had to learn what his crops are taking from the land, in order to learn what he must give back to the land. He has had to learn to take advantage of the tiny bacteria on the roots of clover and peas in order that his corn crops may not fail. He has had to 
learn also to take from the dreary deserts of Chile, and from the desolate, uninhabited islands of the Pacific, the substances which will bring fertility to his exhausted lands. He is learning now to utilise modern chemistry and modern electricity to make nitrogenous manures from the air itself.

In tracing in this way the development of the gardener and farmer of to-day from the first tillers of the ground, we have every now and then stopped to mention certain great names, the names of the men who have stood out from among their fellows, who mark the great periods of change in thought or in methods. But even the shortened story as . we have read it here shows us one fact, a fact which would have been clearer if the story had been told in full. This is that the great men are after all only the milestones which mark the fact that a certain point in the journey has been reached. The great men make progress visible, but this progress would not have been possible if it had not been for the work of the unnoticed toilers, who smoothed the path for the labour of the others.

This is one of the reasons why it is well for us to know the story of the development not of one form of knowledge only, but of many-that we may learn that progress in knowledge, like progress in walking along a road, comes from a great 
number of steps, each one insignificant in itself. The great men mark the fact that during such and such a time so much progress has been made, but the great onward sweep of knowledge has come as truly from the work of the lesser as from that of the greater men. We cannot all do great work; we cannot hope that the work of each one of us will mark the beginning of a period, but we should not forget that the doing of small pieces of work lies within our power, and that is one of the great necessities for progress.

Here is an interesting little quotation from a book by a French author, called Anatole France, on this subject. The hero of the book has been talking to his little boy about the first men of Europe, who lived in caves and had only weapons of flint or of bone, and who yet had learnt many things. He ends up by saying:

"But the task is not yet finished. We should be less generous than the Men of the Caves if, now that our turn has come, we did not strive to render life better and more secure for our children than it is for ourselves. For that there are two secretsloving and knowing. By knowledge and by love the world is made."

We have seen here that what the slow development of agriculture has done has been "to render life better and more secure" for mankind, but in 
this, as in all departments of knowledge, the task is not yet finished, and it is ours to aid it either by our work or by our sympathy with the workers. Only thus can we carry on the work which the men of the Stone Age began.

THE END 


\section{READABLE BOOKS}

\section{IN NATURAL KNOWLEDGE}

Illustrated. Globe 8vo. Is. 6d. each

WONDERS OF PHYSICAL SCIENCE. BY E. E. Fournier, B.Sc.

TILLERS OF THE GROUND. By Marion I. Newbigin, D.Sc.

THREADS IN THE WEB OF LIFE. By Professor J. Arthur Thomson, M.A., and Margaret R. Thomson.

THE PAST AT OUR DOORS. By Walter W. SKEAT.

And others to follow

LONDON : MACMILLAN AND CO., LTD. 


\section{TILLERS}

\section{$\mathrm{OF}$

ax

MARION I. NEWBIGIN, D.Sc.

CONTENTS

Chapter r. Primitive Tillers of the Ground. 2. Reclaiming the Desert. 3. Some Contrasts. 4. The Beginnings of Agriculture. 5. The Spreading of Food-Plants. 6. The Spreading of Food-Plants (continued). 7. Overcoming Difficulties-The Date and the Fig. 8. Introducing Dates into North America. 9. The Story, of the Smyrna Fig. ro. Food and Food-Plants. Ir. The Chief Kinds of Food-Plants. 12. Improving Cultivated Plants. r3. Experiments in Plant-Breeding. 14. Making New Plants. I5. The Struggle with Disease. r6. The Story of Rust in Wheat. I7. Plant Food and the Utilisation of the Soil. I8. The Gains that Knowledge has brought.

\section{THREADS IN \\ THE WEB OF LIFE}

ay

Professor J. ARTHUR THOMSON, M.A. AND MARGARET R. THOMSON

\section{CONTENTS}

Chapter r. Man as Hunter. 2. Domesticated Animals. 3. Domesticated Animals (continued). 4. Earthworms and their Work. 5. Man's Struggle with Animals-The Flesh-eating Animals. 6. Animals which destroy Man's Crops. 7. The Balance of Nature. 8. Pasteur and his Work. 9. Mosquitoes and Malaria. Io. Inter-Relations among Animals. Ir. Aids in the Struggle for Existence. r2. Social Life among Animals. 13. Social Insects. I4. Inter-Relations among Plants. 




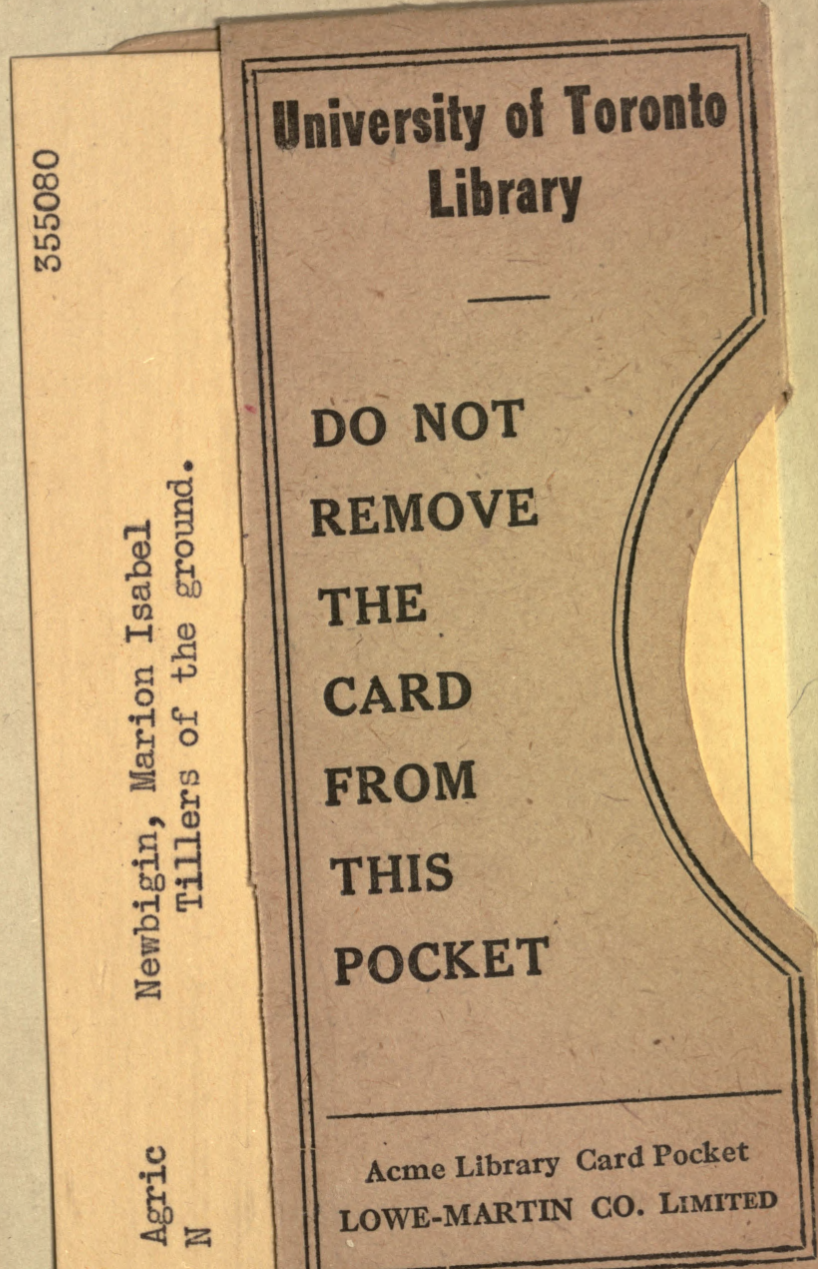


